UNIVERSIDADE DE SÃO PAULO

FACULDADE DE ECONOMIA, AdMINISTRAÇÃo E CONTABILIDADE

Departamento de CONTABILIDADE E ATUÁRIA

\title{
Gerenciamento de Resultados Por
}

BANCos ComerciaIs No Brasil

Paulo Henrique Moura Xavier

OrientAdor: Prof. DR. LUIZ JoÃo CORRAR

SÃo PAULO 
REITOR dA UnIVERSIDADE dE SÃo PAULO

Profa. Dra. Suely VILELA

Diretor da Faculdade de Economia, Administração e Contabilidade

Prof. Dr. Carlos Roberto AZZONI

Chefe do Departamento de Contabilidade e AtuÁRia

Prof. Dr. FÁbIo FreZATTI

Coordenador do Programa de Pós-Graduação em CIÊnCias Contábeis Prof. Dr. Gilberto de AndRade MARTINS 


\section{Gerenciamento de Resultados por}

\section{Bancos ComerciaIs no BrasiL}

Paulo Henrique Moura Xavier

ORIENTADOR: PROF. DR. LUIZ JOÃo CORRAR

Tese apresentada ao Departamento de Contabilidade e Atuária da Faculdade de Economia, Administração e Contabilidade da Universidade de São Paulo, como requisito parcial para a obtenção do título de Doutor em Controladoria e Contabilidade.

SÃo PAULO 


\section{FICHA CATALOGRÁFICA}

Elaborada pela Seção de Processamento Técnico do SBD/FEA/USP

Xavier, Paulo Henrique Moura Gerenciamento de resultados por bancos comerciais no Brasil / Paulo Henrique Moura Xavier. -- São Paulo, 2007. $139 \mathrm{p}$.

Tese (Doutorado) - Universidade de São Paulo, 2007 Bibliografia.

1. Contabilidade bancária 2. Contabilidade de lucros 3. Padrões e normas contábeis I. Universidade de São Paulo. Faculdade de Economia, Administração e Contabilidade II. Título.

CDD -657.8 
Dedico este trabalho à minha esposa Mila e aos meus filhos Pedro e Fábio, pelo apoio, compreensão e incentivo. 
A alegria está na luta, na tentativa, no sofrimento envolvido, não na vitória propriamente dita.

Mahatma Gandhi 


\section{AGRADECIMENTOS}

Meus maiores agradecimentos, sem dúvida, vão para o Prof. Corrar que, desde a época em que eu ainda estava no programa de mestrado, sempre apoiou minhas decisões, sugerindo aperfeiçoamentos, e me encorajou a enfrentar novos e maiores desafios.

Ao Prof. Iran Siqueira Lima, por ter estado sempre presente nos principais momentos da minha vida acadêmica, incentivando-me. Ao Prof. Luiz Paulo Fávero, pelas valiosas sugestões no exame de qualificação e por todo apoio recebido.

Ao Banco Central do Brasil, por investir na qualificação do seu quadro funcional, através de seu Programa de Pós-Graduação Stricto Sensu. Gostaria, também, de agradecer aos colegas de banco que direta ou indiretamente auxiliaram-me nesta empreitada, em especial aos colegas: Donizeti, Fabiano, Rodrigo, Samuel, Gabriel, Rafael e Virgínio.

Finalmente, a todos os professores e colegas do programa de pósgraduação do Departamento de Contabilidade e Atuária. 


\section{RESUMO}

Este trabalho propôs-se a responder se existem indícios suficientes para se afirmar que os bancos comerciais no Brasil praticam alguma modalidade de gerenciamento de resultados. Para tanto, foi verificado se os bancos comerciais selecionados - instituições líderes dos vinte maiores conglomerados bancários brasileiros - utilizaram os ágios em investimentos em controladas e coligadas, as operações com títulos e valores mobiliários, as provisões para operações de crédito ou os passivos contingentes para gerenciar seus resultados.

Dois dos três bancos que possuíam ágios em investimentos em controladas e coligadas efetivamente utilizaram sua amortização para gerenciar seus resultados. Cinqüenta e cinco por cento dos bancos selecionados utilizaram a classificação dos títulos e valores mobiliários para praticar o gerenciamento de resultados. Com relação à provisão para operações de crédito, seis bancos usaram-na para gerenciar seus resultados, outros seis bancos não a usaram e para cinco bancos os resultados foram inconclusivos. Os resultados também foram inconclusivos para os passivos contingentes. 


\section{ABSTRACT}

This thesis purpose is to detect if there are enough signs to assure that Brazilian commercial banks practice any kind of earnings management. For that, it was checked if the selected Brazilian commercial banks - leader institutions of the twenty biggest Brazilian banking conglomerates - used goodwill on acquisitions of subsidiary companies, securities classification, loan loss provisions or contingent and legal liabilities to practice earnings management.

Two of three banks that had goodwill on acquisitions of subsidiary companies effectively used its amortization to manage the banks results. Fifty-five percent of the selected banks did use securities classification to practice earnings management. Regarding the loan loss provisions, six banks used them to manage results, other six banks did not use them to manage results and for five banks the results were inconclusive. The results were also inconclusive for contingent and legal liabilities provisions. 



\section{SUMÁRIO}

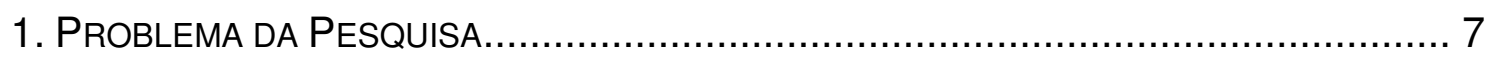

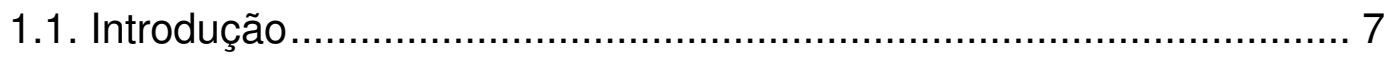

1.2. Bancos e a Amortização do Ágio em 2006 .................................. 11

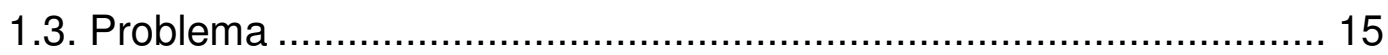

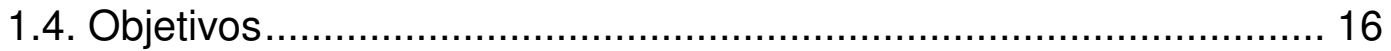

1.5. Metodologia Geral ..................................................... 16

1.6. Estrutura dos Capítulos ................................................ 17

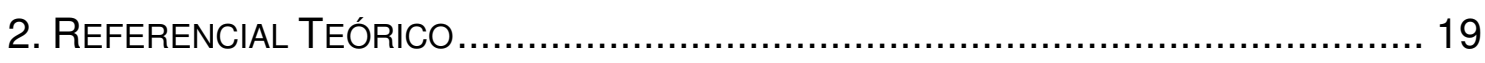

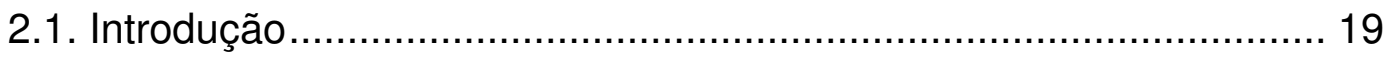

2.2. Trabalhos sobre Gerenciamento de Resultados.......................... 21

2.3. Critérios de Mensuração ...................................................... 30

2.4. Acumulações ............................................................. 33

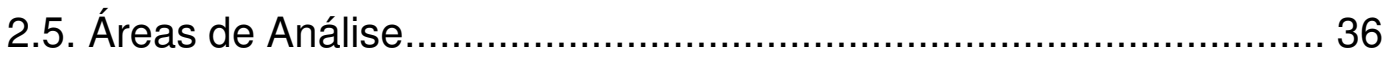

2.5.1. Investimentos em Controladas e Coligadas ....................... 36 
2.5.2. Operações com Títulos e Valores Mobiliários........................ 39

2.5.3. Operações de Crédito........................................................... 42

2.5.4. Passivos Contingentes ................................................... 48

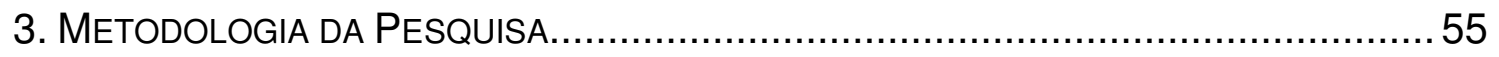

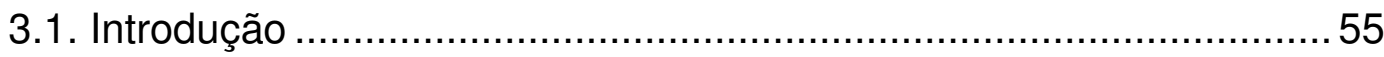

3.2. População e Plano Amostral ...........................................................56

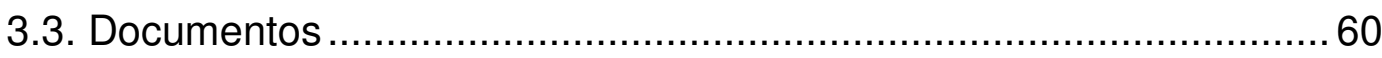

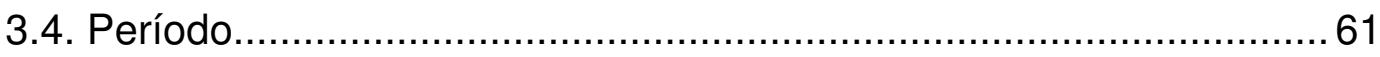

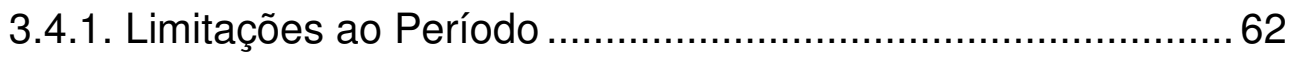

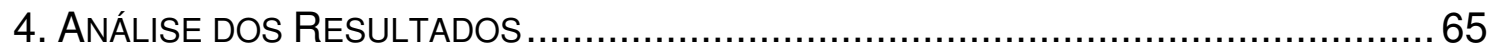

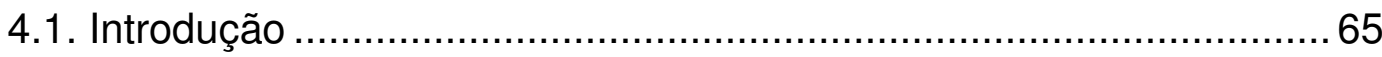

4.2. Investimentos em Controladas e Coligadas ..................................... 66

4.3. Operações com Títulos e Valores Mobiliários ...................................74

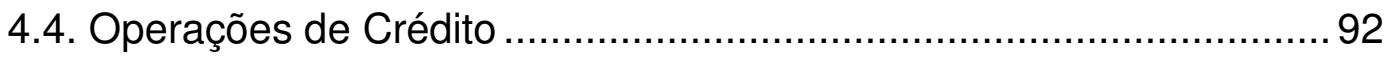

4.5. Passivos Contingentes............................................................ 102

5. CONCLUSÕES E CONSIDERAÇÕES FINAIS ................................................... 105

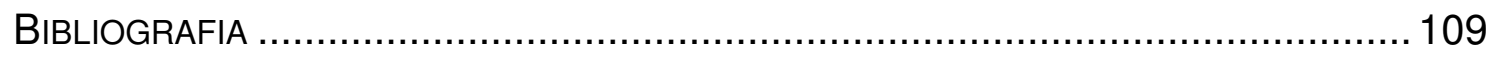

ANEXO 


\section{LISTA DE FIGURAS}

Figura 2.1 - Informações contábeis disponíveis

Figura 2.2 - Grupos de contas no COSIF ................................................ 28

Figura 2.3 - Codificação das contas no COSIF ........................................... 29

Figura 2.4 - Contabilização do ágio na aquisição de investimentos ................ 38

Figura 2.5 - Composição da provisão para operações de crédito ................... 47

Figura 3.1 - Valores acumulados em dez/2006 (R\$ bilhões)........................... 57

Figura 3.2 - Valores acumulados em dez/2006 (R\$ bilhões).......................... 57

Figura 4.1 - Amortização acumulada do ágio em investimentos ..................... 68

Figura 4.2 - Tempo (anos) da amortização do ágio em investimentos............. 68

Figura 4.3 - Exemplo da importância de cada categoria .............................. 75

Figura 4.4 - Composição da carteira do banco L......................................... 79

Figura 4.5 - Composição da carteira do banco A ........................................ 80

Figura 4.6 - Composição da carteira do banco C ........................................ 80

Figura 4.7 - Composição da carteira do banco D ....................................... 80 
Figura 4.8 - Composição da carteira do banco B........................................ 83

Figura 4.9 - Composição da carteira do banco F .......................................... 83

Figura 4.10 - Composição da carteira do banco E....................................... 84

Figura 4.11 - Composição da carteira do banco I .......................................... 84

Figura 4.12 - Composição da carteira do banco M ....................................... 85

Figura 4.13 - Composição da carteira do banco N ....................................... 85

Figura 4.14 - Composição da carteira do banco Q ....................................... 85

Figura 4.15 - Composição da carteira do banco G ...................................... 87

Figura 4.16 - Composição da carteira do banco H ...................................... 87

Figura 4.17 - Composição da carteira do banco J ....................................... 87

Figura 4.18 - Composição da carteira do banco K....................................... 88

Figura 4.19 - Composição da carteira do banco O ........................................ 88

Figura 4.20 - Composição da carteira do banco P....................................... 88

Figura 4.21 - Carteira de títulos mantidos até o vencimento ...........................91

Figura 4.22 - Carteira de títulos para negociação e disponíveis para

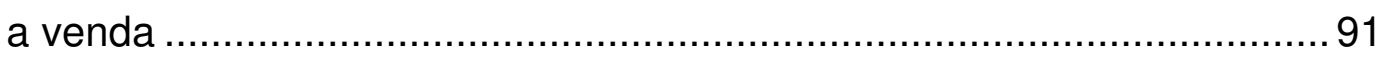

Figura 4.23 - Provisão excedente dos bancos A a E ...................................98

Figura 4.24 - Provisão excedente dos bancos A a E (2)............................... 98

Figura 4.25 - Provisão excedente dos bancos F a I....................................99

Figura 4.26 - Provisão excedente dos bancos J a M ......................................99

Figura 4.27 - Provisão excedente dos bancos $\mathrm{N}$ a Q …............................. 100 


\section{LISTA DE TABELAS}

Tabela 1.1 - Efeitos das decisões no lucro e nos dividendos 14

Tabela 2.1 - Categorias de pesquisa em Gerenciamento de Resultados 25

Tabela 2.2 - Contabilização dos Títulos e Valores Mobiliários 41

Tabela 2.3 - Tratamento contábil relativo às contingências passivas. 51

Tabela 3.1 - Conglomerados bancários brasileiros* 58

Tabela 3.2 - 20 maiores conglomerados bancários brasileiros* 59

Tabela 4.1 - Correlação entre ágio de incorporação e amortização mensal 72

Tabela 4.2 - Importância das categorias na carteira de títulos 77

Tabela 4.3 - Grupos para análises relativas a TVM 78

Tabela 4.4 - Correlação entre os percentuais de TVM em carteira (1). 81

Tabela 4.5 - Correlação entre os percentuais de TVM em carteira (2) 86

Tabela 4.6 - Correlação entre os percentuais de TVM em carteira (3). 89 
Tabela 4.7 - Bancos com indícios de gerenciamento de resultados................90

Tabela 4.8 - Estatísticas sobre provisão excedente dos bancos ..................... 96

Tabela 4.9 - Resultados versus total das operações de crédito ......................99

Tabela 4.10 - Correlação entre provisões e operações de crédito .................101

Tabela 4.11 - Correlação entre provisões e depósitos judiciais.....................103

Tabela 4.12 - Ocorrências por faixas de correlação ………......................... 104

Tabela 5.1 - Resultados obtidos para os 20 maiores conglomerados ........... 107 


\section{Problema da Pesquisa}

\subsection{INTRODUÇÃo}

A Lei $n^{0}$ 6.404, de 15 de dezembro de 1976, conhecida como Lei das Sociedades por Ações, dispõe no $\S 1^{\circ}$ do art. 187 que:

"Na determinação do resultado do exercício serão computados: (a) as receitas e os rendimentos ganhos no período, independentemente da sua realização em moeda; e (b) os custos, despesas, encargos e perdas, pagos ou incorridos, correspondentes a essas receitas e rendimentos".

À primeira vista, a operacionalização de tal conceito parece ser simples, bastando proceder conforme preconizado nas alíneas (a) e (b). No entanto, o próprio conceito de lucro' é alvo de intensas discussões acadêmicas que já duram mais de dois séculos.

John Richard Hicks ( 1904 ¡1989), laureado com o Prêmio Nobel de Economia em 1972, defendia lucro como o montante que uma pessoa (ou

\footnotetext{
${ }^{1}$ Nos textos legais convencionou-se utilizar o termo "resultado" em substituição ao termo "lucro", uma vez que lucro possui sempre uma conotação positiva, enquanto resultado tanto pode ser positivo (lucro) quanto negativo (prejuízo).
} 
empresa) pode gastar durante um período e, ainda, estar tão bem no final do período quanto estava no início.

HENDRIKSEN \& VAN BREDA (1999) possuem uma abordagem muito menos abstrata e mais prática quando discutem o que deve ser incluído no lucro. Apresentam dois conceitos de lucro: (i) o conceito operacional corrente de lucro e (ii) o conceito abrangente de lucro (ou lucro abrangente).

"O conceito operacional corrente de lucro concentra-se na mensuração da eficiência da empresa. O termo eficiência diz respeito à utilização eficaz dos recursos da empresa na realização de suas atividades e na geração de lucros. (...) No cálculo do lucro, ênfase especial é dada aos termos corrente e operacional. Somente as variações de valor e os eventos que são controláveis pela administração e resultam de decisões do período corrente devem ser incluídos. Entretanto, essa afirmação deve ser ressalvada, incluindo-se o uso de fatores adquiridos em períodos anteriores mas usados no período corrente. (...) As variações que devem ser excluídas são aquelas que efetivamente foram causadas em períodos anteriores, mas não haviam sido previamente reconhecidas ou registradas" (HENDRIKSEN \& VAN BREDA, 1999:208).

Esta forma de apresentação do lucro prioriza, portanto, o lucro obtido no período, dando pouca importância e, conseqüentemente, transparência ao lucro de outros períodos. Há que se ressaltar, no entanto, que administradores cujas preocupações éticas sejam pouco representativas em suas decisões ou que não sejam contabilmente idôneos ficariam muito mais tentados a não reconhecerem de imediato algumas despesas - como exige o princípio da 
oportunidade ${ }^{2}$-, visto que se estas despesas fossem reconhecidas somente no período seguinte, elas seriam lançadas contra os lucros e prejuízos acumulados e, assim, nunca transitariam pelo resultado do período. Logo, analistas e investidores pouco atentos teriam maior dificuldade para perceberem a real situação da empresa.

"O segundo aspecto desse conceito [conceito operacional corrente de lucro] é o de que as variações relevantes surgem somente em operações normais, permitindo que se faça uma comparação melhor com outras operações. Embora as atividades não-operacionais também possam ser afetadas pela eficiência da administração, é mais difícil determinar um padrão em relação ao qual os resultados do período possam ser medidos" (HENDRIKSEN \& VAN BREDA, 1999:208).

Quanto a este aspecto, é importante ressaltar que, em muitas situações, as operações não recorrentes podem ter impactos mais significativos que as operações recorrentes no lucro do período e até de períodos posteriores.

"Os defensores do conceito operacional corrente sugerem que o lucro líquido divulgado daí resultante é mais relevante para comparações entre períodos e entre empresas, bem como para a elaboração de predições" (HENDRIKSEN \& VAN BREDA, 1999:208).

Muitas vezes, quando se procura explicitar as bases conceituais da contabilidade ${ }^{3}$, a comparabilidade é relegada a um segundo plano. No entanto,

2 "O Princípio da Oportunidade abarca dois aspectos distintos, mas complementares: a integridade e a tempestividade, razão pela qual muitos autores preferem denominá-lo de Princípio da Universalidade" (IUDíCIBIS, MARTINS \& GELBCKE, 2000:73).

${ }^{3} \mathrm{O}$ Conselho Federal de Contabilidade (CFC) não relaciona a comparabilidade como um princípio, na Resolução oㅜ 750. O Prof. Sérgio de ludícibus, assim como a Comissão de Valores Mobiliários (CVM) e o Instituto Brasileiro dos Auditores Independentes (IBRACON) que encamparam a estrutura conceitual elaborada por este professor, incluem a comparabilidade 
ela possui importância fundamental nas atividades desenvolvidas por uma série de usuários da contabilidade, como analistas, investidores, auditores etc.

"O conceito abrangente de lucro é definido com sendo a variação total do valor do capital, reconhecido pelo registro de transações ou pela reavaliação da empresa durante um período determinado, excetuando-se os pagamentos de dividendos e as transações de aumento ou redução do capital. (...) Os defensores do conceito abrangente de lucro apresentam os seguintes motivos para essa medida do lucro: 1. Os lucros líquidos anuais divulgados, quando somados ao longo de toda a vida da empresa, devem ser iguais ao lucro líquido total da empresa; 2. A omissão de certos lançamentos e créditos do cálculo do lucro líquido presta-se à possibilidade de manipulação ou estabilização do lucro anual. Esse temor tem sido bem fundado há vários anos" (HENDRIKSEN \& VAN BREDA, 1999:209).

O segundo motivo exposto por HENDRIKSEN \& VAN BREDA para a adoção do conceito abrangente de lucro corrobora nossa opinião sobre a possibilidade de manipulação do lucro anual, caso o conceito operacional corrente seja adotado. Contudo, a adoção do conceito abrangente de lucro, por si só, não impede a possibilidade de haver manipulação do resultado.

no âmbito da convenção da consistência. O Financial Accounting Standards Board (FASB), que a inclui em seu referencial conceitual, define-a da seguinte maneira: "a qualidade da informação que permite aos usuários identificar semelhanças e diferenças entre dois conjuntos de fenômenos econômicos". 


\subsection{Bancos e a AmortizaÇÃo do ÁGIO Em 2006}

As manchetes do jornal Valor Econômico relacionadas abaixo ilustram, com fatos reais, a discussão acadêmica desenvolvida no subtítulo anterior:

- "Bradesco amortiza R\$ 2 bi em ágio e faz subscrição" (em 19.09.2006)";

- "Itaú divulga impacto de ágio do Boston” (em 26.10.2006);

- “Unibanco amortiza ágio" (em 27.10.2006)

- "Bradesco e Itaú influenciaram Unibanco a amortizar ágios no 3ํtrimestre" $(\mathrm{em} 09.11 .2006)^{7}$

- "Ágio distorce resultado dos bancos" (em 10.11.2006)8.

No dia 18 de setembro de 2006, o Banco Bradesco S.A. comunicou aos acionistas a decisão da administração de amortizar, no $3^{\circ}$ trimestre de 2006, os ágios de incorporação existentes, que em 30.6.2006 totalizavam $R \$ 2,055$ bilhões, com um impacto líquido no lucro de $\mathrm{R} \$ 1,356$ bilhão.

"O Bradesco registrou, no período de $1^{\circ}$ de janeiro a 30 de setembro/2006, Lucro Líquido de $R \$ 3,351$ bilhões, impactado pela

\footnotetext{
${ }^{4}$ CARVALHO, Maria Christina. Bradesco amortiza R\$ 2 bi em ágio e faz subscrição. Valor Econômico, São Paulo, 19 set. 2006. Disponível em <http://www.valoronline.com.br/valor economico/285/financas/54/Bradesco+amortiza+R $\$+2+$ bi+em+agio+e+faz+subscricao,, ,54,390 2303.html>. Acesso em: 05 nov. 2006.

${ }^{5}$ CARVALHO, Maria Christina \& BASILE, Juliano. Itaú divulga impacto de ágio do Boston. Valor Econômico, São Paulo, 26 out. 2006. Disponível em <http://www.valoronline.com.br/valor economico/285/financas/54/Itau+divulga+impacto+de+agio+do+Boston+,,,54,3969891.html>.

Acesso em: 05 nov. 2006.

${ }^{6}$ VALOR ECONÔMICO. Unibanco amortiza ágio. Valor Econômico, São Paulo, 27 out. 2006. Disponível em <http://www.valoronline.com.br/valoreconomico/285/financas/Unibanco+amortiza +agio,,,55,3973121.html >. Acesso em: 05 nov. 2006.

${ }^{7}$ CAMAROTTO, Murillo. Bradesco e Itaú influenciaram Unibanco a amortizar ágios no $3^{\circ}$ trimestre. Valor Econômico, São Paulo, 09 nov. 2006. Disponível em <http://www.valoronline. com.br/valoronline/Geral/financas/bancos/Bradesco+e+Itau+influenciaram+Unibanco+a+amorti zar+agios+no+3\%c2\%ba+trimestre,,,24,3992540.html>. Acesso em: 15 nov. 2006.

8 CARVALHO, Maria Christina. Ágio distorce resultado dos bancos. Valor Econômico, São Paulo, 10 nov. 2006. Disponível em <http://www.valoronline.com.br/valoreconomico/285/ financas/54/Agio+distorce+resultado+dos+bancos,,,54,3995626.html>. Acesso em: 15 nov. 06.
} 
antecipação da amortização dos Ágios existentes, líquidos de impostos, no total de $R \$ 1,392$ bilhão, que seria efetuada ao longo dos períodos até $O$ ano 2016. Assim, o Lucro Líquido ajustado correspondeu a $R \$$ 4,743 bilhões, representando $R \$ 4,84$ por ação e rentabilidade anualizada de 30,05\% sobre o Patrimônio Líquido final e de 31,49\% sobre o Patrimônio Líquido médio. O retorno anualizado sobre os Ativos Totais foi de 2,61\%, comparado a 2,68\% sobre igual período do ano anterior. (...) A antecipação da amortização dos Ágios, realizada no terceiro trimestre de 2006, além de não ter sido computada no cálculo dos Dividendos e/ou Juros sobre o Capital Próprio distribuídos neste exercício, trará reflexos positivos em resultados futuros, uma vez que a referida despesa não será lançada nesses resultados e, conseqüentemente, na remuneração do capital dos acionistas, naqueles períodos" (BANCO BRADESCO S.A., Relatório da Administração, pág.1).

É interessante observar a preocupação da instituição financeira em divulgar que seu fluxo de distribuição de dividendos e/ou juros sobre o capital próprio não será reduzido no ano de 2006 e será elevado nos anos de 2007 a 2016, pela decisão de antecipar a amortização dos ágios de incorporação.

Cerca de cinco semanas depois, em 25 de outubro de 2006, o Banco Itaú Holding Financeira S.A. divulgou um fato relevante informando que "nas Demonstrações Contábeis Consolidadas do terceiro trimestre de 2.006 já estarão refletidos os efeitos decorrentes da aquisição da operação do BankBoston ('BKB') no Brasil”. Esta instituição financeira também teve a preocupação de divulgar que "o montante de dividendos/JCP [Juros sobre o Capital Próprio] distribuído aos acionistas da ITAÚSA e do ITAÚ, considerando- 
se a nova base acionária do ITAÚ, não será afetado pela amortização do ágio e deverá ser superior ao do exercício de 2.005”.

Finalmente, no dia seguinte, em 26 de outubro de 2006, o Unibanco União de Bancos Brasileiros S.A. também divulgou um fato relevante informando que o Conselho de Administração decidira pela alteração do período para amortização de ágio, que passaria a ser efetuado no período máximo de 5 anos, em substituição ao período de 10 anos utilizado anteriormente. Esta instituição também julgou relevante divulgar que "o cálculo de Juros sobre Capital Próprio e/ou Dividendos referentes ao exercício de 2006 não será afetado pelo impacto extraordinário da aceleração de amortização de ágio. O montante total de Juros sobre Capital Próprio/Dividendos será, no mínimo, de $35 \%$ do lucro líquido do exercício, desconsiderando-se o efeito extraordinário de amortização de ágio no terceiro trimestre de 2006, após a constituição da reserva legal".

A Tabela 1.1 relaciona as decisões tomadas por estes três conglomerados financeiros brasileiros, no que tange à antecipação da amortização dos ágios de incorporação, com os efeitos que tais decisões tiveram no lucro e nos dividendos. Analisando-se as decisões e seus efeitos, percebe-se quão pertinentes são as considerações feitas na discussão acadêmica sobre o conceito operacional corrente de lucro e o conceito abrangente de lucro. O Itaú, com sua decisão de mostrar apenas quais seriam os efeitos da amortização total dos ágios de incorporação no lucro consolidado, sequer permite alguém afirmar qual dos conceitos ele tende a utilizar, uma vez que o lucro da holding tenderá para o conceito operacional corrente de lucro e o lucro do consolidado tenderá para o conceito abrangente de lucro. 
Tabela 1.1 - Efeitos das decisões no lucro e nos dividendos

\begin{tabular}{|c|c|c|c|}
\hline Instituição & Decisão Tomada & Efeitos no Lucro & $\begin{array}{l}\text { Efeitos nos } \\
\text { Dividendos }\end{array}$ \\
\hline Bradesco & $\begin{array}{l}\text { Antecipar toda a } \\
\text { amortização dos } \\
\text { ágios de } \\
\text { incorporação }\end{array}$ & $\begin{array}{l}\text { O lucro líquido de } 2006 \\
\text { será consideravelmente } \\
\text { menor, enquanto os dos } \\
\text { demais anos serão } \\
\text { maiores }\end{array}$ & $\begin{array}{l}\text { A instituição } \\
\text { comprometeu-se em } \\
\text { alterar sua política de } \\
\text { distribuição de } \\
\text { dividendos de forma a } \\
\text { expurgar os efeitos da } \\
\text { decisão }\end{array}$ \\
\hline Itaú & $\begin{array}{l}\text { Refletir apenas no } \\
\text { consolidado, os } \\
\text { efeitos da } \\
\text { amortização dos } \\
\text { ágios de } \\
\text { incorporação }\end{array}$ & $\begin{array}{l}\text { Os efeitos restringem-se } \\
\text { ao lucro do consolidado, } \\
\text { que não possui impacto } \\
\text { nos dividendos }\end{array}$ & $\begin{array}{l}\text { Não há efeitos nos } \\
\text { dividendos, pois o lucro } \\
\text { líquido da holding não é } \\
\text { afetado }\end{array}$ \\
\hline Unibanco & $\begin{array}{l}\text { Acelerar o } \\
\text { processo de } \\
\text { amortização dos } \\
\text { ágios de } \\
\text { incorporação }\end{array}$ & $\begin{array}{l}\text { O lucro líquido será } \\
\text { menor em } 2006, \\
\text { enquanto os dos demais } \\
\text { anos serão ligeiramente } \\
\text { maiores }\end{array}$ & $\begin{array}{l}\text { A instituição } \\
\text { comprometeu-se em } \\
\text { alterar sua política de } \\
\text { distribuição de } \\
\text { dividendos de forma a } \\
\text { expurgar os efeitos da } \\
\text { decisão }\end{array}$ \\
\hline
\end{tabular}

As decisões tomadas pelos bancos, apesar de serem até diametralmente diferentes, possuem uma importante característica comum: todas elas estão em conformidade com a legislação vigente. Poder-se-ia discutir a aderência delas aos princípios contábeis, contudo este não é o foco deste trabalho, que pretende estudar o gerenciamento de resultados.

"De acordo com as motivações envolvidas, podemos ter várias modalidades de "gerenciamento" dos resultados contábeis (earnings management), entre as quais caberia destacar: (1) "Gerenciamento" dos resultados contábeis para aumentar ou diminuir os lucros. Os resultados são "gerenciados" de modo a atingir determinadas "metas" de referência que podem ser acima ou abaixo do resultado do período; (2) "Gerenciamento" dos resultados contábeis para reduzir a variabilidade 
(Income Smoothing). $O$ propósito é manter os resultados em determinado patamar e evitar sua excessiva flutuação; (3) "Gerenciamento" dos resultados contábeis para reduzir lucros correntes em prol de lucros futuros (Take a Bath ou Big Bath Accounting). As empresas gerenciam os seus resultados correntes piorando-os, tendo como propósito ter melhores resultados no futuro" (MARTINEZ, 2001:42).

O problema dos ágios de incorporação exposto acima pode ser enquadrado na terceira modalidade de gerenciamento de resultado apresentada. Entretanto, não seria necessário fazer um esforço tão grande para observar também traços das duas outras modalidades de gerenciamento de resultado nas decisões tomadas pelos conglomerados financeiros citados.

\subsection{Problema}

Em face da situação real apresentada, em que três importantes conglomerados financeiros brasileiros decidem alterar de forma significativa suas práticas contábeis, os efeitos que estas decisões trarão a vários dos usuários das informações contábeis disponibilizadas por estes conglomerados e as justificativas utilizadas para se praticar o gerenciamento de resultados, este trabalho se propõe a responder a seguinte questão:

Existem indícios suficientes para se afirmar que os bancos comerciais no Brasil praticam alguma modalidade de gerenciamento de resultados? 


\subsection{OBJETIVOS}

Este trabalho tem como objetivos, verificar se os bancos comerciais no Brasil utilizam (i) os investimentos em controladas e coligadas, (ii) as operações com títulos e valores mobiliários, (iii) as operações de crédito ou (iv) os passivos contingentes para gerenciar seus resultados.

Desta forma, a consecução dos objetivos acima descritos conduzirá à resposta para a questão de pesquisa proposta.

\subsection{Metodologia Geral}

A metodologia empregada neste trabalho pode receber as seguintes classificações (MARTINS apud SILVA JUNIOR, 2006:18):

- Empírico-analítica - “... são abordagens que apresentam em comum a utilização de técnicas de coleta, tratamento e análise de dados marcadamente quantitativas. Privilegiam estudos práticos. Suas propostas têm caráter técnico, restaurador e incrementalista. Têm forte preocupação com a relação causal entre variáveis. A validação da prova científica é buscada através de testes dos instrumentos, graus de significância e sistematização das definições operacionais";

- Descritiva - “... tem como objetivo a descrição das características de determinada população ou fenômeno, bem como o estabelecimento de relações entre variáveis e fatos";

- Ex post facto - “... tipo de investigação empírica na qual o pesquisador não tem controle direto sobre a(s) variável(eis) independente(s), porque suas 
manifestações já ocorreram, ou porque ela(s) é(são), por sua natureza, não manipulável(eis)".

\subsection{Estrutura dos Capítulos}

O capítulo 2 conterá o Referencial Teórico. Primeiro será analisada a literatura, sobretudo a brasileira, sobre gerenciamento de resultados. Depois o tema será desenvolvido no que tange aos bancos comerciais.

No capítulo 3 será apresentada a Metodologia da Pesquisa, que consiste no caminho utilizado para seu desenvolvimento, além das justificativas para seleção da amostra, documentos e períodos utilizados.

O capítulo 4 conterá o resultado das análises relativas às diversas áreas investigadas, com o objetivo de se colher os indícios sobre gerenciamento de resultado para que seja possível responder à questão de pesquisa.

Finalmente, o capítulo 5 será destinado às considerações finais e conclusões, seguido da bibliografia e do anexo. 


\section{REFERENCIAL TEÓRICO}

\subsection{INTRODUÇÃO}

"Apesar das anedotas da imprensa especializada na área financeira sustentarem a visão de que muito provavelmente os resultados são gerenciados, esta evidência anedótica não estabelece uma base sólida para se pensar sistematicamente e de modo produtivo sobre gerenciamento de resultados. A questão é complexa; determinar e demonstrar a existência do gerenciamento de resultados em um modelo analítico ou em um cenário empírico requer pensamento cuidadoso e criativo sobre vários problemas conceituais e sobre várias escolhas na modelagem de pesquisa. Interpretar os resultados das pesquisas de gerenciamento de resultados, por sua vez, requer a avaliação das escolhas feitas pelos pesquisadores para resolver aqueles problemas conceituais e sobre a modelagem de pesquisa" (SCHIPPER, 1989:100).

\footnotetext{
${ }^{9}$ Tradução livre de: "While anecdotes from the financial press support the view that is more likely than not that earnings are managed, such anecdotal evidence does not provide a solid basis for thinking systematically and productively about earnings management. The issue is complex; motivating and demonstrating the existence of earnings management in an analytic model or in an empirical setting requires careful and creative thinking about both a number of conceptual issues and a number of research design choices. Interpreting the results of earnings
} 
Pode-se dizer que o tema gerenciamento de resultados começou a ser estudado internacionalmente na década de 1980, ganhando fôlego na década seguinte. Contudo no Brasil, somente a partir de MARTINEZ (2001) é que a pesquisa nesta área ganhou força.

Ao fazer a revisão da literatura então existente, MARTINEZ (2001) verificou que as principais perguntas de pesquisa dos trabalhos sobre gerenciamento de resultados eram "há?" e "por quê?". Poucos trabalhos exploraram as questões "como?" e "quais são os efeitos?".

“(1) Há? - Está ocorrendo gerenciamento dos resultados contábeis? Quem está praticando e em que magnitude?

(2) Por quê? - Por que os resultados contábeis são gerenciados? Qual é o incentivo para os gestores administrarem os Resultados? Onde a administração acha motivação para "gerenciar" resultados?

(3) Como? - Como a administração manipula ${ }^{10}$ resultados? Quais componentes da demonstração financeira são usados para "gerenciar"?

(4) Quais são os efeitos? - Quais são as conseqüências deste comportamento?" (MARTINEZ, 2001:38).

Este trabalho tem como objetivo responder a questão "há?". No entanto, a resposta para tal questão será obtida à medida que a questão "como?" for respondida. Em outras palavras, este trabalho analisará as formas que os

management research, in turn, requires evaluating the tradeoffs made by the researcher in resolving those conceptual issues and making research design choices".

10 Talvez o termo "manipula" não seja o mais indicado. O próprio autor fez a seguinte observação em outro ponto de seu trabalho: "É crucial entender que "gerenciamento" dos resultados contábeis, não é fraude contábil. Ou seja, opera-se dentro dos limites do que prescreve a legislação contábil, entretanto nos pontos em que as normas contábeis facultam certa discricionariedade para o gerente, este realiza suas escolhas não em função do que dita 
bancos comerciais poderiam utilizar para a prática do gerenciamento de resultados; destas análises buscará concluir se este é utilizado ou não por eles. As questões "por quê?" e "quais são os efeitos?" não serão objeto de estudo.

\subsection{Trabalhos sobre Gerenciamento de Resultados}

Pode-se dizer que os trabalhos mais citados internacionalmente são aqueles que apresentaram modelos para proxies das acumulações discricionárias, isto é, modelos que fornecem estimativas ou aproximações para os valores das acumulações discricionárias. Os modelos mais citados são: o modelo de JONES (1991) ${ }^{11}$, o modelo Jones Modificado (1995) - proposto por DECHOW, SLOAN \& SWEENY (1995) ${ }^{12}$ - e o modelo KS (1995), proposto por KANG \& SIVARAMAKRISHNAN $(1995)^{13}$.

No Brasil, depois de MARTINEZ (2001), vários trabalhos começaram a ser publicados. Os dois trabalhos seguintes - MATOS \& SANCOVSCHI (2003) e CUPERTINO (2004) $)^{14}$ - foram estudos de casos. MATOS \& SANCOVSCHI (2003) avaliaram o caso da Lucent Technologies, buscando avaliar que incentivos os administradores tinham para gerenciar resultados e quais evidências sugeriam que os resultados haviam sido realmente gerenciados. Já CUPERTINO (2004) teve como objetivo "investigar a gestão fraudulenta de

a realidade concreta dos negócios, mas em função de outros incentivos, que o levam a desejar reportar um resultado distinto" (MARTINEZ, 2001:13).

${ }^{11}$ JONES, Jeniffer J. Earnings management during import relief investigations. Journal of Accounting Research. Chicago, V. 29, N. 2, Autumn 1991.

${ }_{12}$ DECHOW, Patricia M.; SLOAN, Richard G. \& SWEENEY, Amy P. Detecting earnings management. The Accounting Review, v. 70, n. 2, 1995.

${ }^{13}$ KANG, Sok-Hyon \& SIVARAMAKRISHNAN, K. Issues in testing earnings management: an instrumental variable approach. Journal of Accounting Research, V. 33, N. 2, 1995.

${ }^{14}$ CUPERTINO, César Medeiros. Gerenciamento fraudulento de resultados contábeis: o caso banco nacional. In: Encontro da ANPAD (EnANPAD), 28., 2004, Curitiba. 
lucros do Banco Nacional S.A., tanto nos seus aspectos motivadores, quanto em relação aos seus efeitos na composição patrimonial da entidade".

Ainda em 2004, foram apresentadas duas dissertações no programa de mestrado em Controladoria e Contabilidade da FEA/USP: FUJI (2004) e TUKAMOTO (2004). Enquanto FUJI (2004) buscou verificar se havia gerenciamento de resultados contábeis no âmbito das instituições financeiras atuantes no Brasil, TUKAMOTO (2004) investigou e comparou "os níveis de 'gerenciamento' de resultados das companhias brasileiras registradas na Bolsa de Valores de São Paulo emissoras de ADRs e não emissoras de ADRs".

MARTINEZ (2001) havia classificado os trabalhos existentes na literatura internacional conforme as perguntas de pesquisa - "há?", "por quê?", "como?" e "quais são os efeitos?".

Nacionalmente, tiveram como objetivo principal responder à pergunta "há?" - "Está ocorrendo gerenciamento dos resultados contábeis? Quem está praticando e em que magnitude?" (MARTINEZ, 2001:38) - os trabalhos de ALMEIDA, LOPES, TONIATO \& COSTA (2005) e ALMEIDA, COSTA, FARIA \& BRANDÃO (2006). Em ALMEIDA, LOPES, TONIATO \& COSTA (2005) investigou-se o gerenciamento de resultados em relação à classificação setorial chegando a resultados relevantes para apenas quatro dos vinte setores da Economática. O modelo KS (1995) foi o utilizado. Por sua vez, ALMEIDA, COSTA, FARIA \& BRANDÃO (2006) avaliaram o gerenciamento de resultados em vinte e um grupos estratégicos existentes entre dez setores da economia brasileira. "Foram encontradas evidências de gerenciamento de resultados em sete grupos estratégicos segundo o modelo de Jones modificado DSS (1995) e em nove grupos estratégicos segundo o modelo KS (1995)". 
A pergunta "por quê?" - "Por que os resultados contábeis são gerenciados? Qual é o incentivo para os gestores administrarem os Resultados? Onde a administração acha motivação para 'gerenciar' resultados?" (MARTINEZ, 2001:38) - foi objeto dos estudos de PAULO (2006) e SILVEIRA (2006). PAULO (2006) buscou relacionar o gerenciamento de resultados e a oferta pública de ações pelas companhias abertas brasileiras. Acabou por não comprovar a hipótese de que as acumulações discricionárias são aumentadas significativa e positivamente com o objetivo de inflacionar os preços das ações, como havia sido constatado internacionalmente. Já SILVEIRA (2006) analisou as companhias abertas listadas nos Níveis 1 e 2 de Governança Corporativa na Bovespa que remuneram seus executivos por meio de Opções de Ações, chegando à conclusão de que não existem evidências de maiores níveis de gerenciamento de resultados em relação às empresas que não remuneram seus executivos desta forma. Para tanto, utilizou os modelos de Jones (1991), Jones modificado (1995) e KS (1995);

Quatro trabalhos dedicaram-se à pergunta "como?" - "Como a administração manipula resultados? Quais componentes da demonstração financeira são usados para 'gerenciar'?" (MARTINEZ, 2001:38). CARDOSO \& MARTINEZ (2006) procuraram investigar se o gerenciamento de resultados é praticado por meio de decisões operacionais, além das acumulações discricionárias. Chegaram à conclusão que, de fato, as decisões operacionais também são utilizadas para se gerenciar resultados. Por sua vez, RODRIGUES (2006), que avaliou o gerenciamento dos resultados através das contas de receitas e despesas não-operacionais, no âmbito das empresas brasileiras classificadas como "Nível 1" de governança corporativa pela BOVESPA, 
chegou à conclusão que existem indícios do gerenciamento de resultados, contudo estes indícios precisam ser melhor avaliados com testes mais robustos. CORRAR, PAULO \& MARTINS (2007) verificaram "se a análise do diferimento tributário aumenta significativamente a detecção do gerenciamento de resultados nas companhias abertas brasileiras", chegando à conclusão de que tal análise não aumenta o poder preditivo dos modelos Jones modificado (1995) e KS (1995). Finalmente, RODRIGUES, PAULO \& CARVALHO (2007) analisaram "se as companhias abertas brasileiras utilizam as transações entre empresas interligadas, especificamente quando da existência de relação de controle, para gerenciar os resultados (...) transferir resultados da controlada para controladora ou vice-versa". Constataram haver indícios de gerenciamento de resultados, "porém, não há evidências de que isso esteja sendo feito por meio das transações entre empresas interligadas".

O tema governança corporativa, tão em voga neste início de século, também foi analisado - CARDOSO, AQUINO, ALMEIDA \& NEVES (2006) e RAMOS \& MARTINEZ (2006). Contudo, estes trabalhos não tiveram como objetivo responder a nenhuma das perguntas anteriormente elencadas. Juntamente com o trabalho de PAULO, LIMA \& LIMA (2006), que analisou a influência da cobertura por analistas financeiros, poder-se-ia inaugurar uma nova categoria na classificação de pesquisas em gerenciamento de resultados, aquelas que objetivam analisar se "existem mitigadores", isto é, possuem como perguntas de pesquisas típicas: "As práticas associadas à governança corporativa conseguem mitigar o gerenciamento de resultados? $O$ acompanhamento da empresa por analistas financeiros evita ou diminui a administração de resultados?". 
Tabela 2.1 - Categorias de pesquisa em Gerenciamento de Resultados

\begin{tabular}{ll}
\hline Categoria & Perguntas de Pesquisa \\
\hline Há? & Está ocorrendo gerenciamento dos resultados contábeis? \\
& Quem está praticando e em que magnitude? \\
\hline Por quê? & Por que os resultados contábeis são gerenciados? \\
& Qual é o incentivo para os gestores administrarem os Resultados? \\
& Onde a administração acha motivação para 'gerenciar' resultados? \\
\hline Como? & Como a administração realiza o gerenciamento de resultados? \\
& Quais componentes da demonstração financeira são usados para \\
\hline Quais são os & Querenciar'? \\
\hline efeitos? & Quais são as conseqüências deste comportamento? \\
\hline Existem & As práticas associadas à governança corporativa conseguem mitigar o \\
mitigadores? & gerenciamento de resultados? \\
& O acompanhamento da empresa por analistas financeiros evita ou \\
& diminui a administração de resultados? \\
\hline
\end{tabular}

Adaptado e ampliado de (MARTINEZ, 2001:38)

CARDOSO, AQUINO, ALMEIDA \& NEVES (2006) investigaram "se a intensidade de acumulações discricionárias (ADs) é diferente para empresas cujo nível de governança corporativa é certificado pela Bovespa comparativamente àquelas que não o são; e para empresas cujas ações negociadas na Bovespa têm alto nível de liquidez comparadas àquelas cujos títulos têm baixa liquidez". Concluíram que as diferenças não são estatisticamente significativas, tendo utilizado o modelo Jones (1991). RAMOS \& MARTINEZ (2006), por sua vez, procuraram "verificar qual a associação entre as práticas de governança corporativa e a propensão ao gerenciamento de resultados no Brasil. (...) Os resultados indicam que as empresas do novo mercado, níveis 1, 2 e 3, apresentam uma menor variabilidade nas acumulações discricionárias (discritionary accruals) quando comparada àquela das empresas que não aderiram ao programa". O modelo utilizado foi o de Jones (1991). Concluiu-se que existe maior propensão ao gerenciamento de resultados em empresas com fraca governança corporativa. PAULO, LIMA \& 
LIMA (2006), que tinham como objetivo verificar se as companhias abertas brasileiras cobertas pelos analistas financeiros apresentavam diferentes níveis de discricionariedade em relação às que não são cobertas, não confirmaram sua hipótese de pesquisa. Utilizaram, no desenvolvimento da pesquisa, os modelos Jones modificado (1995) e KS (1995).

De todos estes trabalhos acadêmicos, um único trabalho - FUJI (2004) analisa o gerenciamento de resultados nas instituições financeiras brasileiras. Entretanto, há uma diferença fundamental entre o trabalho de FUJI (2004) e este trabalho.

"As bases de dados utilizadas são os balancetes semestrais das instituições financeiras publicados durante o período de junho de 1996 a junho de 2003, segundo informações do site do Banco Central do Brasil" (FUJl, 2004:70).

"No estudo empírico, consideramos os dados semestrais dos bancos comerciais e múltiplos atuantes no Brasil, incluindo o Banco do Brasil, a Caixa Econômica Federal e os bancos estrangeiros, no período de junho de 1996 a junho de 2003, segundo informações do site do Banco Central do Brasil" (FUJI, 2004:82).

“A pesquisa não pode detectar, por exemplo, se há manipulação no tocante à classificação nos diversos níveis de risco. Os aspectos referentes à inadimplência também não foram abordados, tendo em vista que são dados sob sigilo bancário" (FUJI, 2004:98).

Como demonstrado acima, FUJI (2004) utiliza somente dados de domínio público para efetuar suas análises - disponibilizados na página do 
Banco Central do Brasil ${ }^{15}$ (a Figura 2.1 apresenta um extrato das informações contábeis disponíveis referentes ao conglomerado bancário Banco do Brasil) -, enquanto este trabalho utilizará dados fornecidos ao órgão supervisor que, no entanto, não são disponibilizados ao público em geral.

Figura 2.1 - Informações contábeis disponíveis

\begin{tabular}{|c|c|c|c|c|c|c|}
\hline & & $\begin{array}{r}\text { Evoluçăo dos Sa } \\
\qquad\end{array}$ & dos Contábeis & & & \\
\hline & & ATI & & & & \\
\hline & & & Balanço & & Balan & \\
\hline Conta & Nome & $\begin{array}{c}\text { Jun/2005 } \\
\text { Rs Mil }\end{array}$ & $\begin{array}{l}\text { Dez/2005 } \\
\text { R\$ Mil }\end{array}$ & $\begin{array}{l}\text { Jun } / 2006 \\
\text { R\$ Mil }\end{array}$ & $\begin{array}{l}\text { Dez/2005 } \\
\text { R\$ Mil }\end{array}$ & $\begin{array}{c}\text { Dez } / 2006 \\
\text { R\$ Mil }\end{array}$ \\
\hline 1.0.0.00.00-7 & CIRCULANTE E REAL A LONG PRAZO & 228.776 .457 & 247.396 .627 & 268.159 .375 & 247.396 .627 & 290.562 .295 \\
\hline 1.1.0.00.00-6 & DISPONIELLIDADES & 3.464 .089 & 5.027 .663 & 5.019 .066 & 5.027 .653 & 4.748 .797 \\
\hline 1.1.1.00.00-9 & CANXA & 2.449 .709 & 2.638 .019 & 2.773 .182 & 2.688 .019 & 3.641 .603 \\
\hline 1.1.2.00.00-2 & DEPOSITOS BANCARIOS & 565.490 & 2.568 .960 & 655.353 & 2.568 .960 & \\
\hline 1.1.3.00.00-5 & RESERVAS UUVES & & & 1.393 .562 & & \\
\hline 1.1.4.00.00-8 & APLICACOES EM OURO & 2.903 & 3.723 & 4.729 & 3.723 & 5.328 \\
\hline 1.1.5.00.00-1 & DISPONIEIL. EM MOEDAS ESTRANG. & 445.986 & 566.960 & 192.239 & 566.960 & 1.101 .866 \\
\hline $1.2 .0 .00 .00-5$ & APUCACOES INTERF DE UQUIDEZ & 17.378 .811 & 28.944 .322 & 29.757 .833 & 28.944 .322 & 29.087 .697 \\
\hline $1.2 .1 .00 .00-8$ & APUC EM OPER COMPROMISSADAS & 2.117 .580 & 8.049 .830 & 19.910 .095 & 8.049 .830 & 17.489 .570 \\
\hline $1.2 .2 .00 .00-1$ & APUC EM DEP INTERFINANCEIROS & 15.251 .716 & 20.835 .743 & 9.847 .738 & 20.835 .743 & 11.582 .908 \\
\hline 1.2.6.00.00-3 & APUICA OES MOEDAS ESTRANGEIRAS & 9.515 & 58.748 & & 58.748 & 15.219 \\
\hline $1.3 \cdot 0 \cdot 00.00-4$ & TIT.E VAL_MOB.E INST.FIN.DER. & 68.973 .041 & 66.470 .116 & 70.511 .205 & 66.470 .116 & 72.927 .146 \\
\hline 1.3.1.00.00-7 & UVRES & 29.222 .350 & 37.665 .255 & 32.967 .892 & 37.665 .255 & 34.035 .013 \\
\hline $1.3 .2 .00 .00-0$ & VINCUL A OPER COMPROMISSADAS & 35.778 .100 & 24.830 .085 & 31.312 .521 & 24.830 .085 & 32.612 .393 \\
\hline 1.3.3.00.00-3 & INST. FINANCEIROS DERIVATIVOS & 1.354 .602 & 286.600 & 463.086 & 286.600 & 563.983 \\
\hline $1.3 .4 .00 .00-6$ & VINCULADOS AO BANCO CENTRAL & 2.320 .893 & 3.258 .198 & 3.963 .732 & 3.258 .198 & 3.873 .125 \\
\hline 1.3.6.00.00-2 & VINC. A PRESTACAO DE GARANTIAS & 297.016 & 429.979 & 433.604 & 429.979 & 1.342 .348 \\
\hline 1.3.7.00.00-5 & TITULOS OBJ. OPER. COMP. LIVRE & & & 1.370 .368 & & 500.283 \\
\hline $3.1 .0 .00 .00-0$ & CLASSIF. CARTEIRA DE CREOITOS & 96.167 .594 & 101.751 .303 & 113.112 .033 & 101.731 .303 & 133.141 .210 \\
\hline $3.1 .1 .00 .00-3$ & OPERACOES DE RISCO NIVEL Aa & 17.395 .712 & 18.399 .606 & 17.103 .727 & 18.399 .606 & 32.953 .250 \\
\hline $3.1 .2 .00 .00-6$ & OPERACOES DE RISCO NIVEL A & 28.410 .321 & 29.174 .155 & 30.795 .604 & 29.174 .155 & 32.010 .658 \\
\hline 3.1.3.00.00-9 & OPERACOES DE RISCO NIVELB & 30.901 .395 & 31.363 .897 & 34.499 .034 & 31.363 .897 & 40.659 .855 \\
\hline 3.1.4.00.00-2 & OPERACOES DE RISCO NINELC & 11.241 .333 & 13.302 .069 & 17.624 .014 & 13.302 .069 & 15.469 .788 \\
\hline $3.1 .5 .00 .00-5$ & OPERACOES DE RISCO NIVEL D & 3.413 .869 & 3.412 .893 & 5.236 .110 & 3.412 .893 & 4.200 .864 \\
\hline $3.1 \cdot 6.00 .00-8$ & OPERACOES DE RISCO NIVEL E & 857.479 & 1.174 .673 & 1.451 .389 & 1.174 .673 & 1.954 .654 \\
\hline $3.1 .7 .00 .00-1$ & OPERACOES DE RISCO NIVEL F & 548.636 & 727.375 & 785.241 & 727.375 & 693.431 \\
\hline $3.1 .8 .00 .00-4$ & OPERACOES DE RISCO NIVEL G & 411.575 & 804.327 & 893.798 & 804.327 & 981.074 \\
\hline 3.1.9.00.00-7 & OPERACOES DE RISCO NIVEL H & 2.987 .275 & 3.422 .308 & 4.643 .116 & 3.422 .308 & 4.157 .606 \\
\hline
\end{tabular}

Esta figura foi extraída diretamente da página do Banco Central do Brasil na internet.

Como o objetivo era ilustrar com um exemplo as informações que lá podem ser obtidas, optou-se por reduzir a figura, apesar da baixa qualidade gráfica resultante.

${ }^{15}$ As informações contábeis sobre conglomerados financeiros, bancos comerciais, bancos múltiplos e caixas econômicas podem ser acessadas a partir da pagina <http://www5.bcb.gov.br/fis/cosif/principal.asp?id=if>. Acesso em: 4 set. 2007. 
"A instituição não pode alterar ou modificar qualquer elemento caracterizador da conta padronizada, ou seja: código, título, subtítulo ou função" (COSIF 1.1.4.5).

Nos balanços semestrais (junho e dezembro) e nos balancetes mensais enviados pelas instituições financeiras ao Banco Central do Brasil, as contas são padronizadas e possuem um código identificador. O primeiro dígito deste código indica o grupo do balanço (ou balancete) a que pertence a conta. Os grupos existentes estão relacionados na Figura 2.2, conforme disposto no Plano Contábil das Instituições do Sistema Financeiro Nacional (doravante apenas COSIF) 1.1.4.3.

Figura 2.2 - Grupos de contas no COSIF

\begin{tabular}{|c|c|}
\hline ATIVO & PASSIVO \\
\hline \multirow[t]{2}{*}{$\begin{array}{l}\text { 1- Circulante e } \\
\quad \text { Realizável a Longo Prazo }\end{array}$} & $\begin{array}{l}\text { 4- Circulante e Exigível a Longo Prazo } \\
5 \text { - Resultados de Exercícios Futuros }\end{array}$ \\
\hline & $\begin{array}{l}6 \text { - Patrimônio Líquido } \\
7 \text { - Contas de Resultado Credoras } \\
8 \text { - Contas de Resultado Devedoras }\end{array}$ \\
\hline 3 - Compensação & 9 - Compensação \\
\hline
\end{tabular}

A codificação das contas obedece a uma estrutura lógica, que tem como objetivo tornar as informações acessíveis segundo um determinado nível de detalhamento. Existem cinco níveis de detalhamento - grupos, subgrupos, desdobramentos de subgrupos, títulos contábeis e subtítulos contábeis -, sendo o primeiro nível o mais sintético e o quinto, o mais analítico. 
Figura 2.3 - Codificação das contas no COSIF

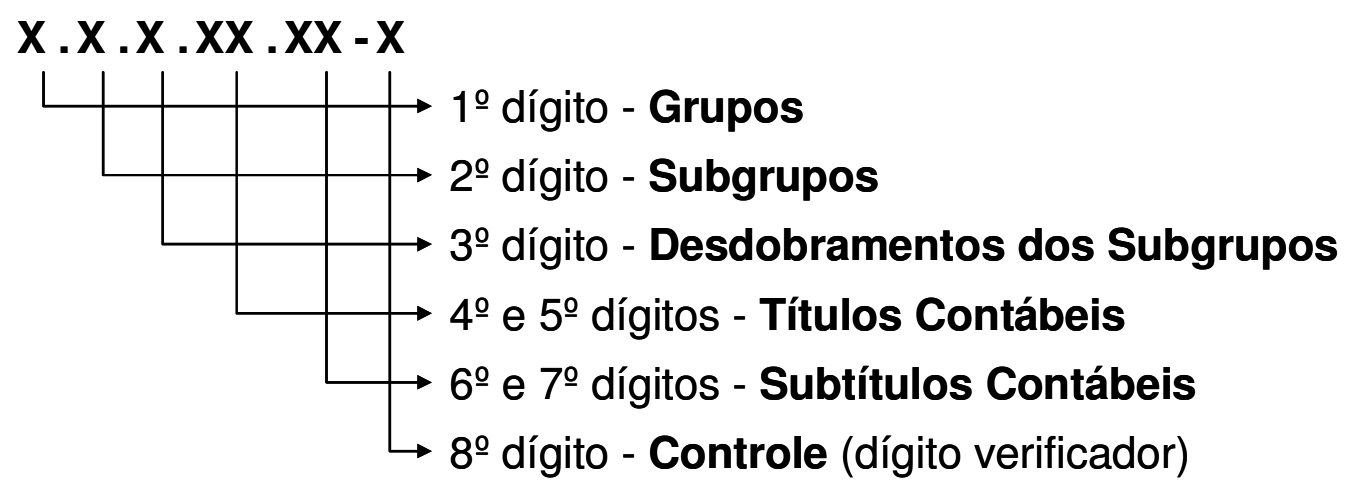

O Banco Central do Brasil, em sua página na internet, disponibiliza ao público as informações prestadas pelas instituições financeiras ${ }^{16}$ até o terceiro nível (como exemplificado na Figura 2.1), isto é, o nível dos "Desdobramentos dos Subgrupos". Entretanto, este trabalho utilizará várias informações contidas nos níveis "Títulos Contábeis" (quarto nível) e "Subtítulos Contábeis" (quinto nível), conforme será exposto adiante no item 2.5.

Em virtude deste fato, o conteúdo da Lei Complementar ㄲo 105, de 10 de janeiro de 2001, que dispõe sobre o sigilo das operações de instituições financeiras, deverá ser observado. Assim, os resultados e conclusões a serem apresentados neste trabalho não conterão informações que permitam individualizar as análises, ou seja, eles serão divulgados tendo em vista o conjunto das instituições financeiras analisadas, nunca sendo divulgadas informações sobre uma única instituição financeira, um pequeno grupo delas, ou de uma forma que permita identificar a instituição financeira em questão.

16 "O teor das informações é de responsabilidade das instituições financeiras, representadas por seus administradores, gerentes, membros do conselho de administração, fiscal e semelhantes, e a sua inexatidão sujeita-os às penalidades previstas em lei”. Disponível em: <http://www5.bcb.gov.br/fis/cosif/principal.asp?id=if>. Acesso em: 4 set. 2007. 


\subsection{Critérios de Mensuração}

A contabilidade, apesar de trabalhar basicamente com números, está elencada no rol das ciências humanas e sociais. Poucos valores nas Demonstrações Contábeis possuem valor exato, isto é, valor não suscetível de diferentes avaliações. Entre eles estão: numerário em caixa, número de ações em circulação, data ou período de referência da demonstração.

"Evidentemente, o processo decisório decorrente das informações apuradas pela Contabilidade não se restringe apenas aos limites da empresa, aos administradores e gerentes (usuários internos), mas também a outros segmentos, quais sejam, usuários externos" (IUDÍCIBUS \& MARION, 2000:42).

A contabilidade destina-se a atender uma ampla gama de usuários investidores, credores, fornecedores, funcionários, governo etc. ${ }^{17}$ - cada um deles com objetivos e interesses próprios, assim, pode-se dizer, que cada grupo utiliza as informações contábeis para uma aplicação própria.

"A quantidade de medidas diferentes reflete a variedade de aplicações da contabilidade, pois cada aplicação sugere uma medida distinta. Em conseqüência, embora haja vantagem clara na aceitação geral de um único conceito abrangente, uma análise mais atenta dos padrões de utilização indica que um único conceito de avaliação não seria capaz de atender igualmente bem todas as finalidades. O conceito apropriado, em cada caso, exige que se conheça quem usará a informação e para que fim" (HENDRIKSEN \& VAN BREDA, 1999:304). 
Diante disso, é possível conceber várias formas de mensuração de um mesmo ativo ou passivo. HENDRIKSEN \& VAN BREDA (1999) e IUDÍCIBUS (2000) destacam que a mensuração pode estar baseada tanto em valores de entrada quanto em valores de saída. Os dois primeiros autores indicam que os valores de entrada podem ser calculados com base em valores passados (custos históricos), valores correntes (custos de reposição) e valores futuros

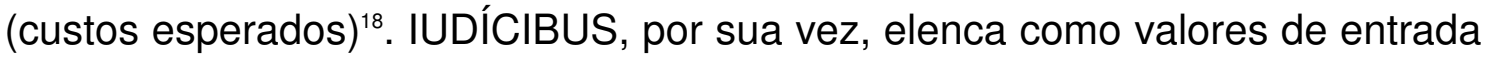
possíveis: custo histórico, custos correntes (de reposição, na data) e custo corrente corrigido pelas variações do poder aquisitivo da moeda. Este último autor ressalta ainda que, alguns autores admitem que o princípio da continuidade é respeitado mesmo com a mensuração através de valores de saída, porém é inadmissível pensar na descontinuidade da empresa mantendo-se a mensuração por valores de entrada.

Com o estabelecimento de princípios contábeis ${ }^{19}$, que têm como objetivo pautar, nortear e, de certo modo, padronizar a contabilização das operações e a elaboração das demonstrações, alguns destes valores de entrada ou de saída deixam de poder ser utilizados. No entanto, a possibilidade de se utilizar critérios de mensuração diversos ainda persiste, tanto que a Lei das Sociedades por Ações (Lei ํㅜ 6.404/1976, artigo 176, § 5º), a Comissão de Valores Mobiliários (CVM) e o Banco Central do Brasil estabelecem que os critérios de avaliação precisam estar incluídos nas Notas Explicativas às Demonstrações Contábeis, visando torná-las mais compreensíveis aos

\footnotetext{
17 Comumente, tanto na literatura técnica como na científica, é utilizada a expressão inglesa "stakeholders" para designar esta ampla gama de usuários.

18 De maneira similar, os valores de saída podem ser calculados com base em valores passados (preços de venda passados), valores correntes (preço corrente de venda) e valores futuros (valor realizável esperado).
} 
usuários e passíveis de comparação com as demonstrações contábeis de outras empresas.

As instituições financeiras, que por determinação do Conselho Monetário Nacional estão sujeitas à regulamentação do Banco Central do Brasil, devem utilizar o Plano Contábil das Instituições do Sistema Financeiro Nacional (COSIF) no que tange aos procedimentos contábeis que devem ser observados (Capítulo 1 do COSIF - Normas Básicas), ao elenco de contas em que as operações devem ser registradas (Capítulo 2 do COSIF - Elenco de Contas) e à forma de elaboração e apresentação dos documentos contábeis (Capítulo 3 do COSIF - Documentos).

"As normas consubstanciadas neste Plano Contábil têm por objetivo uniformizar os registros contábeis dos atos e fatos administrativos praticados, racionalizar a utilização de contas, estabelecer regras, critérios e procedimentos necessários à obtenção e divulgação de dados, possibilitar o acompanhamento do sistema financeiro, bem como a análise, a avaliação do desempenho e o controle, de modo que as demonstrações financeiras elaboradas, expressem, com fidedignidade e clareza, a real situação econômico-financeira da instituição e conglomerados financeiros" (COSIF, item 1.1.1.1).

O fato das instituições financeiras possuírem um plano de contas e critérios de contabilização muito mais detalhados do que os critérios estabelecidos para empresas industriais ou comerciais, pode, a princípio, fazer crer que as demonstrações contábeis das instituições financeiras sejam muito

\footnotetext{
${ }^{19}$ Os princípios contábeis podem variar de país para país e também ao longo do tempo, atendendo a idiossincrasias do local ou da época em questão.
} 
menos suscetíveis a variações em seus valores em virtude de escolhas de critérios de mensuração. No entanto, não é isto que verifica na prática.

Enquanto as empresas industriais ou comerciais possuem, como uma parte significativa de seus ativos, bens tangíveis, as instituições financeiras trabalham, basicamente, com direitos de crédito. Os bens tangíveis, normalmente, apresentam uma menor variabilidade nos valores de realização, obtidos segundo os diferentes critérios de mensuração que poderiam ser utilizados, do que os direitos de crédito das instituições financeiras. Tal constatação é uma das justificativas apresentadas para a necessidade de maior regulação do sistema financeiro, em relação aos setores industriais e comerciais.

Conclui-se, então, que os valores apresentados nas demonstrações contábeis das instituições financeiras podem apresentar sensíveis variações, conforme os critérios de mensuração adotados.

\subsection{ACUMULAÇõeS}

A Resolução no 750/1993 do Conselho Federal de Contabilidade (CFC), que dispõe sobre os Princípios Fundamentais de Contabilidade, determina que as receitas e despesas devem ser confrontadas para a formação do resultado do período em que ocorrerem, independentemente de seu recebimento ou pagamento. Raras são as situações e fortes são os motivos que levam ao não reconhecimento de gastos como despesas do período ou de rendas como receitas do período.

\section{"Seção VI - O PRINCÍPIO DA COMPETÊNCIA}


Art. $9^{\circ}$ As receitas e as despesas devem ser incluídas na apuração do resultado do período em que ocorrerem, sempre simultaneamente quando se correlacionarem, independentemente de recebimento ou pagamento.

$\S 1^{\circ} \mathrm{O}$ Princípio da COMPETÊNCIA determina quando as alterações no ativo ou no passivo resultam em aumento ou diminuição no patrimônio líquido, estabelecendo diretrizes para classificação das mutações patrimoniais, resultantes da observância do Princípio da OPORTUNIDADE ${ }^{20}$.

$\S 2^{\circ} \mathrm{O}$ reconhecimento simultâneo das receitas e despesas, quando correlatas, é conseqüência natural do respeito ao período em que ocorrer sua geração" (Resolução CFC no 750/1993).

Esta forma de registro é denominada regime de competência, enquanto que a forma de registro baseada nas entradas e saídas de recursos do caixa da empresa é denominada regime de caixa. Assim, a contabilidade calcula o lucro líquido segundo o regime de competência, que não guarda relação direta com o fluxo de caixa da empresa.

"Na literatura internacional, a diferença entre o lucro líquido e o fluxo de caixa líquido é conhecida com accruals. Ou seja, as acumulações

\footnotetext{
${ }^{20}$ Seção III - O PRINCÍPIO DA OPORTUNIDADE

Art. $6^{\circ} \mathrm{O}$ Princípio da OPORTUNIDADE refere-se, simultaneamente, à tempestividade e à integridade do registro do patrimônio e das suas mutações, determinando que este seja feito de imediato e com a extensão correta, independentemente das causas que as originaram.

Parágrafo único. Como resultado da observância do Princípio da OPORTUNIDADE:

I - desde que tecnicamente estimável, o registro das variações patrimoniais deve ser feito mesmo na hipótese de somente existir razoável certeza de sua ocorrência;

II - o registro compreende os elementos quantitativos e qualitativos, contemplando os aspectos físicos e monetários;

III - o registro deve ensejar o reconhecimento universal das variações ocorridas no patrimônio da ENTIDADE, em um período de tempo determinado, base necessária para gerar informações úteis ao processo decisório da gestão.
} 
(accruals) seriam todas aquelas contas de resultado que entraram no cômputo do lucro, mas que não implicam em necessária movimentação de disponibilidades. (...) Nas operações usuais da empresa, espera-se que, com certa freqüência, sejam feitos lançamentos que terão a natureza de acumulações (accruals). Isso ocorre em função do princípio da competência. O volume de acumulações no resultado dependerá, muitas vezes, da natureza do negócio e de certas estimativas e avaliações que os gestores realizarem" (MARTINEZ, 2001:16).

Os gestores podem registrar estas acumulações - que não possuem efeitos imediatos ${ }^{21}$ no caixa - compulsoriamente, em virtude de determinações legais ou regulamentares, ou podem registrá-las discricionariamente, em função da conveniência e oportunidade.

O gerenciamento de resultado, objeto de estudo deste trabalho, surge exatamente desta conveniência e oportunidade.

"O gerenciamento de resultados, também conhecido por Contabilidade Criativa, constitui $o$ ato de atuar, de forma intencional, sobre os resultados contábeis, presumivelmente dentro dos limites estabelecidos pelas normas e práticas contábeis, quer emanadas de legislação, quer de órgãos normatizadores, considerando-se o poder discricionário dos preparadores de demonstrações contábeis na seleção de alternativas freqüentemente permitidas na utilização de tais normas" (FUJI, 2004:3).

${ }^{21}$ O Caixa sempre será sensibilizado, porém esta sensibilização pode ter ocorrido antes do momento do registro da acumulação - no caso da depreciação ou amortização -, como também pode ocorrer num momento futuro ainda não completamente definido - no caso das provisões. 


\section{5. ÁreAs de ANÁLISE}

Os bancos comerciais podem registrar várias acumulações discricionárias, sendo que este estudo enfocará as relativas a: (i) investimentos em controladas e coligadas, (ii) operações com títulos e valores mobiliários, (iii) operações de crédito e (iv) passivos contingentes.

\subsubsection{InVestimentos em Controladas e Coligadas}

“O patrimônio líquido poderia ser reavaliado a mercado usando-se uma conta de reavaliação, e uma conta de 'goodwill' poderia ser incluída entre os ativos. (...) Goodwill representa vantagens que não são especificamente identificáveis. (...) Quando uma empresa é comprada, o preço pago pode ser alocado, de alguma forma, às contas da empresa compradora. A prática americana consiste em alocar o máximo possível do preço de compra a ativos específicos, indicando o resíduo como goodwill. O goodwill é reconhecido, portanto, por diferença" (HENDRIKSEN \& VAN BREDA, 1999:390).

Quando uma empresa pretende adquirir outra empresa, elabora-se um "balanço de negociação" para que possa ser avaliado o valor patrimonial da empresa adquirida. Se houver diferença entre o valor pago e este valor patrimonial calculado, surgirá a figura do ágio ou deságio. Assim, o ágio de incorporação surgirá quando o valor pago for superior ao valor patrimonial da empresa incorporada. 
“24. Para efeito de contabilização, o custo de aquisição de investimento em coligada ou em controlada deverá ser desdobrado e os valores resultantes desse desdobramento contabilizados em subcontas separadas: a) equivalência patrimonial baseada em balanço patrimonial ou intercalar levantado até, no máximo, sessenta dias antes da data de aquisição pela investidora ou pela controladora; b) ágio ou deságio na aquisição, representado pela diferença para mais ou para menos, respectivamente, entre o custo de aquisição do investimento e a equivalência patrimonial" (IBRACON NPC nำ6).

Segundo a Instrução CVM no $247^{22}$, o ágio de incorporação deve ser contabilizado com indicação do fundamento econômico que o determinou. Os fundamentos econômicos suscetíveis de contabilização são: (i) diferença entre o valor contábil e o valor de mercado dos ativos da coligada ou controlada, e (ii) diferença entre o valor pago e o valor de mercado dos ativos da coligada ou controlada. Esta segunda diferença pode ocorrer devido a: (i) expectativas de resultados futuros, ou (ii) em virtude de fundo de comércio, ativos intangíveis ou outras razões econômicas.

A Figura 2.4 sintetiza as diferenças entre os três ágios que podem ser pagos nas aquisições de investimentos em controladas ou coligadas.

${ }^{22}$ Versão consolidada com as alterações introduzidas pelas Instruções CVM no 269/1997 e no 285/1998. Disponível em <http://www.cvm.gov.br/asp/cvmwww/atos/exiato.asp?file=linstlinst 247consolid.htm>. Acesso em: 13 nov. 2006. 
Figura 2.4 - Contabilização do ágio na aquisição de investimentos

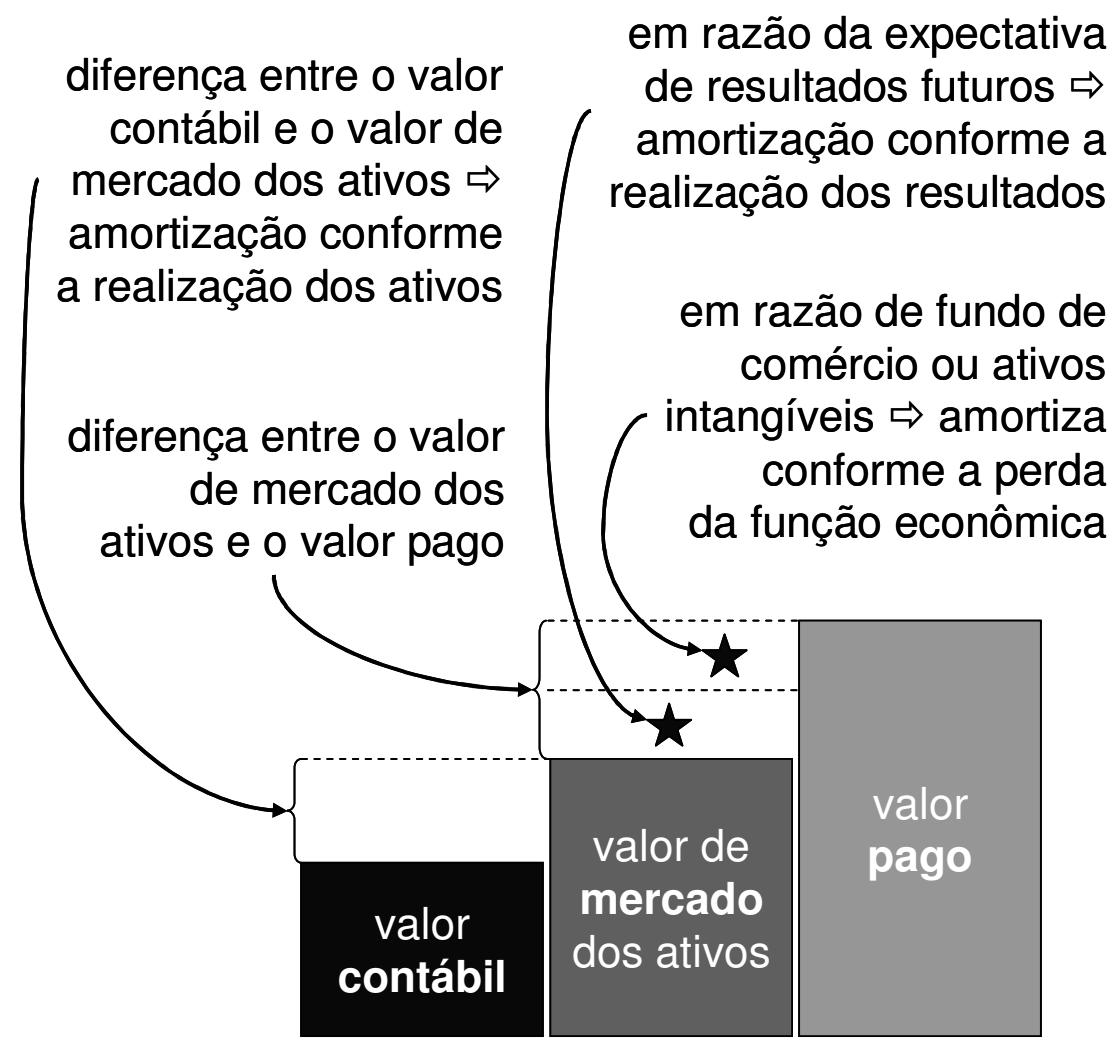

Apesar dos ágios de incorporação precisarem ser registrados pelos bancos comerciais segregadamente, de acordo com o fundamento econômico que o originou, o COSIF não possui abertura para este tipo de registro, devendo estas informações serem mantidas apenas em subcontas de uso interno destas instituições financeiras. No referido plano de contas, estão disponíveis os seguintes títulos contábeis:

- Ágios de Incorporação $\left(2 \cdot 4 \cdot 1 \cdot 10.00-0^{23}\right)$, cuja função é lançar o valor do ágio existente na incorporada ${ }^{24}$;

\footnotetext{
23 "A codificação das contas observa a seguinte estrutura: (a) 1ํdígito - GRUPOS: I - Ativo: 1 Circulante e Realizável a Longo Prazo; 2 - Permanente; 3 - Compensação; II - Passivo: 4 Circulante e Exigível a Longo Prazo; 5 - Resultados de Exercícios Futuros; 6 - Patrimônio Líquido; 7 - Contas de Resultado Credoras; 8 - Contas de Resultado Devedoras; 9 Compensação; (b) 2ำ dígito - SUBGRUPOS; (c) $3^{\circ}$ dígito - DESDOBRAMENTOS DOS SUBGRUPOS; (d) 4ำ e 5 dígitos - TíTULOS CONTÁBEIS; (e) 6ำ e 7ํ dígitos - SUBTÍTULOS CONTÁBEIS; (f) 8oígito - CONTROLE (dígito verificador)" (COSIF 1.1.4.3).
} 
- Amortização Acumulada do Diferido (2.4.1.99.00-7), subtítulo Ágios de Incorporação (2.4.1.99.10-0), cuja função é registrar o valor das amortizações acumuladas do Diferido.

Assim, a pesquisa a ser realizada no âmbito deste trabalho terá a limitação de tratar todos as espécies de ágios de incorporação de maneira única, indistinta, apesar das particularidades inerentes a da cada um deles.

\subsubsection{Operações com Títulos e Valores Mobiliários}

Com a Circular ํㅜ 3068 do Banco Central do Brasil, de 8 de novembro de 2001, as instituições financeiras brasileiras passaram a ser obrigadas a classificar os títulos e valores mobiliários (TVM) adquiridos nas seguintes categorias: (i) títulos para negociação, (ii) títulos disponíveis para venda e (iii) títulos mantidos até o vencimento.

Na categoria títulos para negociação, devem ser registrados os títulos e valores mobiliários adquiridos com 0 propósito de serem ativa e freqüentemente negociados. Por outro lado, na categoria títulos mantidos até o vencimento, devem ser registrados os títulos e valores mobiliários para os quais haja intenção e capacidade financeira da instituição de mantê-los em carteira até o vencimento. Já na categoria títulos disponíveis para venda, devem ser registrados os títulos e valores mobiliários que não se enquadrem em nenhuma das outras duas categorias.

${ }^{24}$ Esta conta também tem como função "registrar as despesas previstas no art. 3o, inciso I, do Decreto-lei no 2.075, de 20 de dezembro de 1983, destinadas à amortização consoante autorização do Conselho Monetário Nacional" (COSIF 2.2). 
Os títulos e valores mobiliários classificados nas categorias títulos para negociação ou títulos disponíveis para venda devem ser ajustados pelo valor de mercado, no mínimo por ocasião dos balancetes e balanços. Já os títulos e valores mobiliários classificados na categoria títulos mantidos até 0 vencimento, devem ser avaliados pelos respectivos custos de aquisição, acrescidos dos rendimentos auferidos, os quais devem impactar o resultado do período. Em outras palavras, este títulos devem estar registrados por um valor teórico que reflita a apropriação dos rendimentos segundo a relação do tempo decorrido desde sua aquisição e o período até seu vencimento.

A contabilização dos títulos e valores mobiliários classificados na categoria títulos para negociação difere da contabilização dos títulos da categoria títulos disponíveis para venda, pois os ajustes a valores de mercado (valorizações ou desvalorizações) possuem diferentes contrapartidas: (i) à adequada conta de receita ou despesa, no resultado do período, quando relativa a títulos e valores mobiliários classificados na categoria títulos para negociação, e (ii) à conta destacada do patrimônio líquido, quando relativa a títulos e valores mobiliários classificados na categoria títulos disponíveis para venda, pelo valor líquido dos efeitos tributários.

Desta forma, os bancos comerciais, ao decidirem classificar os títulos e valores mobiliários na categoria títulos para negociação ou na categoria títulos disponíveis para venda, decidem, indiretamente, se os ganhos ou perdas relativos aos ajustes dos títulos e valores mobiliários ao valor de mercado transitarão imediata ou mediatamente - quando de sua efetiva realização - no resultado do período. 
"Os ganhos ou perdas não realizados registrados em conta destacada do patrimônio líquido, na forma do disposto na alínea " $b$ " do item $7^{25}$, devem ser transferidos para o resultado do período quando da venda definitiva dos títulos e valores mobiliários classificados na categoria títulos disponíveis para venda" (COSIF 1.4.1.9).

Diferentemente do que ocorre com a classificação dos títulos e valores mobiliários na categoria títulos mantidos até o vencimento, em que os bancos comerciais precisam provar capacidade financeira para mantê-los em carteira até o vencimento ${ }^{26}$, a classificação dos títulos e valores mobiliários nas categorias títulos para negociação ou títulos disponíveis para venda exige apenas a intenção. Logo, esta decisão possui um considerável potencial para abarcar o gerenciamento de resultados, visto que os critérios de contabilização são significativamente diferentes.

Tabela 2.2 - Contabilização dos Títulos e Valores Mobiliários

\begin{tabular}{lll}
\hline Categoria & Contabilização & Ajustes \\
\hline Para negociação & Marcado a mercado & Diretamente no resultado \\
\hline Disponível para venda & Marcado a mercado & No patrimônio líquido \\
\hline Mantido até o vencimento & Curva do papel & Não há ajustes \\
\hline
\end{tabular}

${ }^{25}$ 7. Os títulos e valores mobiliários classificados nas categorias referidas no item 1, alíneas "a" [títulos para negociação] e "b" [títulos disponíveis para venda], devem ser ajustados pelo valor de mercado, no mínimo por ocasião dos balancetes e balanços, computando-se a valorização ou a desvalorização em contrapartida:

a) à adequada conta de receita ou despesa, no resultado do período, quando relativa a títulos classificados na categoria títulos para negociação;

b) à conta destacada do patrimônio líquido, quando relativa a títulos classificados na categoria títulos disponíveis para venda, pelo valor líquido dos efeitos tributários (COSIF 1.4.1.7).

${ }^{26}$ A capacidade financeira de que trata 0 item 4 deve ser comprovada com base em projeção de fluxo de caixa, desconsiderada a possibilidade de venda dos títulos mantidos até o vencimento (COSIF 1.4.1.5). 
Diante do exposto, os títulos e valores mobiliários classificados na categoria títulos mantidos até o vencimento não serão analisados no âmbito deste trabalho. Serão analisados, então, os seguintes títulos contábeis:

- Títulos para Negociação (3.0.3.30.00-1 - conta de compensação), cuja função é registrar o valor de mercado dos títulos e valores mobiliários adquiridos com o propósito de serem ativa e freqüentemente negociados, sem prejuízo do adequado registro em contas patrimoniais;

- Títulos Disponíveis para Venda (3.0.3.40.00-8 - conta de compensação), cuja função é registrar o valor de mercado dos títulos e valores mobiliários que não se enquadrem nas categorias títulos para negociação e títulos mantidos até o vencimento, sem prejuízo do adequado registro em contas patrimoniais;

- Títulos Mantidos até o Vencimento (3.0.3.50.00-5 - conta de compensação), cuja função é registrar o valor de custo acrescido dos rendimentos auferidos e deduzido das perdas de caráter permanente com títulos e valores mobiliários, exceto ações não resgatáveis, para os quais haja intenção e capacidade financeira da instituição de mantê-los em carteira até o vencimento, sem prejuízo do adequado registro em contas patrimoniais.

\subsubsection{Operações de Crédito}

Usualmente, as operações de crédito são classificadas nas seguintes modalidades: (i) empréstimos, que são as operações realizadas sem destinação específica ou vínculo à comprovação da aplicação dos recursos (por exemplo: empréstimos para capital de giro, empréstimos pessoais, 
adiantamentos a depositantes etc.), (ii) títulos descontados, que são as operações de desconto de títulos (por exemplo: duplicatas, recebíveis etc.), e (iii) financiamentos, que são as operações realizadas com destinação específica, vinculadas à comprovação da aplicação dos recursos (por exemplo: financiamentos de máquinas e equipamentos, financiamentos de bens de consumo durável, financiamentos imobiliários etc.). As operações de crédito são consideradas como uma das principais atividades e, conseqüentemente, uma das principais fontes de receitas dos bancos comerciais.

O risco de crédito está relacionado à incerteza quanto ao fluxo de caixa prometido, principalmente, pelos emissores de títulos e valores mobiliários e pelos tomadores de operações de crédito. Em outras palavras, risco de crédito é o risco de não recebimento no prazo e/ou nas condições pactuadas, tanto do principal quanto dos juros devidos, que o doador de recursos ou o emprestador possui.

"A adequada constituição de provisão para créditos de liquidação duvidosa e a avaliação de riscos são de extrema importância para a saúde financeira dos bancos, de modo a preservar uma boa imagem perante o público e a continuidade de suas operações" (FUJl, 2004: 79).

De acordo com o disposto na Resolução no 2682, de 21 de dezembro de 1999, as instituições financeiras e demais instituições autorizadas a funcionar pelo Banco Central do Brasil devem classificar as operações de crédito, em ordem crescente de risco, nos seguintes níveis: AA, A, B, C, D, E, F, G e H.

$\mathrm{Na}$ operacionalização da classificação das operações de crédito as instituições financeiras devem considerar: (i) tanto as informações sobre o devedor e seus eventuais garantidores - situação econômico-financeira, grau 
de endividamento, capacidade de geração de resultados, fluxo de caixa, administração e qualidade de controles, pontualidade e atrasos nos pagamentos, contingências, setor de atividade econômica, limite de crédito (ii) quanto as informações relativas à operação em questão - natureza e finalidade da transação, valor, características das garantias, particularmente quanto à suficiência e liquidez.

"O momento no qual uma despesa deve ser registrada é determinado, em parte, pelo enfoque de definição do lucro proposto explícita ou implicitamente. A definição de lucro como variação de valor geralmente indica que as despesas devem ser registradas sempre que há uma redução de valor ou quando não há benefício ou valor evidente a ser recebido no futuro, em decorrência do uso desses bens ou serviços. $O$ conceito de lucro que enfatiza fluxos de caixa conduz à conclusão de que as despesas devem ser registradas tão proximamente da saída efetiva de caixa quanto seja razoável. A contabilidade tradicional por competência situa-se entre esses dois extremos, mas pende para 0 conceito de valor" (HENDRIKSEN \& VAN BREDA, 1999:236).

A teoria contábil, como exposto acima, fornece as justificativas utilizadas pelos administradores tanto para o incremento quanto para a diminuição da provisão para créditos de liquidação duvidosa. Contudo, esta discricionariedade dos administradores possui limites: os fixados na regulamentação emitida, principalmente, pelo Conselho Monetário Nacional e pelo Banco Central do Brasil.

"A provisão para fazer face aos créditos de liquidação duvidosa deve ser constituída mensalmente, não podendo ser inferior ao somatório 
decorrente da aplicação dos percentuais a seguir mencionados, sem prejuízo da responsabilidade dos administradores das instituições pela constituição de provisão em montantes suficientes para fazer face a perdas prováveis na realização dos créditos: a) 0,5\% sobre o valor das operações classificadas como de risco nível $A$; b) $1 \%$ sobre o valor das operações classificadas como de risco nível B; c) 3\% sobre o valor das operações classificadas como de risco nível C; d) 10\% sobre o valor das operações classificados como de risco nível D; e) 30\% sobre o valor das operações classificados como de risco nível E; f) $50 \%$ sobre o valor das operações classificados como de risco nível F; g) 70\% sobre o valor das operações classificados como de risco nível G; h) $100 \%$ sobre o valor das operações classificadas como de risco nível H" (COSIF 1.6.2.7).

Deste modo, para a consecução dos objetivos deste trabalho, será necessário analisar os seguintes títulos contábeis:

- Provisão para Operações de Crédito ${ }^{27}$ (1.6.9.00.00-8), cuja função é registrar os valores provisionados decorrentes da classificação das operações de crédito nos diferentes níveis de risco em função das características do devedor e seus garantidores, bem como da operação;

- Operações de Crédito Nível AA (3.1.1.10.00-0 - conta de compensação), cuja função é registrar os valores contábeis dos créditos classificados no

\footnotetext{
${ }^{27} \mathrm{Na}$ realidade esta conta do COSIF não se refere a um título contábil, mas a um desdobramento de subgrupo, que é a união de vários títulos contábeis, a saber: provisão para empréstimos e títulos descontados (1.6.9.20.00-2), provisão para financiamentos (1.6.9.30.009), provisão para financiamentos rurais e agroindustriais (1.6.9.40.00-6), provisão para financiamentos imobiliários (1.6.9.50.00-3) provisão para financiamentos de títulos e valores mobiliários (1.6.9.60.00-0), provisão para financiamentos de infraestrutura e desenvolvimento (1.6.9.70.00-7), provisão para perdas na realização de operações de crédito (1.6.9.97.00-4).
} 
nível de risco AA em função das características do devedor e seus garantidores, bem como da operação;

- Operações de Crédito Nível A (3.1.2.10.00-3 - conta de compensação), cuja função é registrar os valores contábeis dos créditos classificados no nível de risco A em função das características do devedor e seus garantidores, bem como da operação;

- Operações de Crédito Nível B (3.1.3.10.00-6 - conta de compensação), cuja função é registrar os valores contábeis dos créditos classificados no nível de risco B em função das características do devedor e seus garantidores, bem como da operação;

- Operações de Crédito Nível C (3.1.4.10.00-9 - conta de compensação), cuja função é registrar os valores contábeis dos créditos classificados no nível de risco C em função das características do devedor e seus garantidores, bem como da operação;

- Operações de Crédito Nível D (3.1.5.10.00-2 - conta de compensação), cuja função é registrar os valores contábeis dos créditos classificados no nível de risco D em função das características do devedor e seus garantidores, bem como da operação;

- Operações de Crédito Nível E (3.1.6.10.00-5 - conta de compensação), cuja função é registrar os valores contábeis dos créditos classificados no nível de risco E em função das características do devedor e seus garantidores, bem como da operação;

- Operações de Crédito Nível F (3.1.7.10.00-8 - conta de compensação), cuja função é registrar os valores contábeis dos créditos classificados no nível de 
risco F em função das características do devedor e seus garantidores, bem como da operação;

- Operações de Crédito Nível G (3.1.8.10.00-1 - conta de compensação), cuja função é registrar os valores contábeis dos créditos classificados no nível de risco $\mathrm{G}$ em função das características do devedor e seus garantidores, bem como da operação;

- Operações de Crédito Nível H (3.1.9.10.00-4 - conta de compensação), cuja função é registrar os valores contábeis dos créditos classificados no nível de risco $\mathrm{H}$ em função das características do devedor e seus garantidores, bem como da operação.

Figura 2.5 - Composição da provisão para operações de crédito

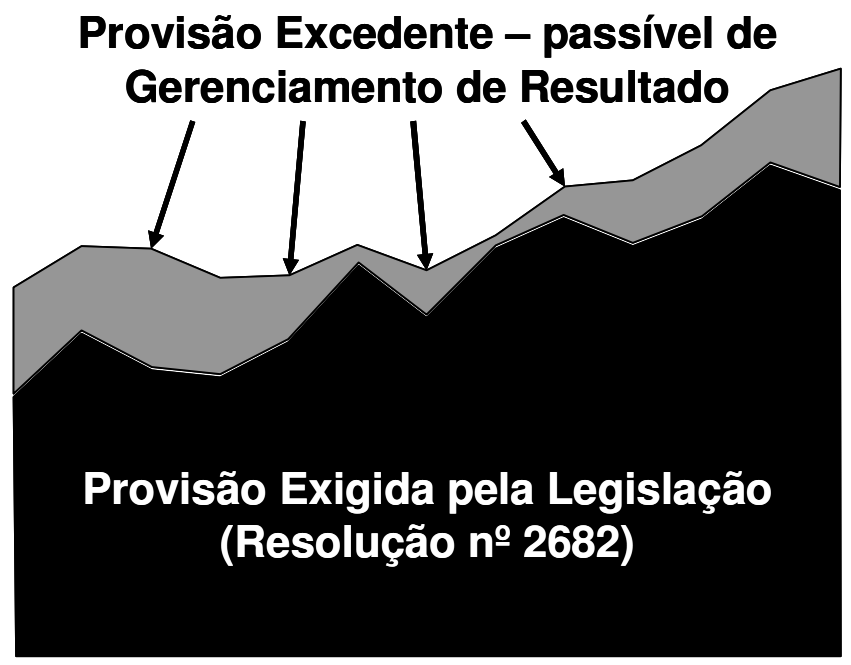

A análise das contas elencadas acima permitirá que seja calculado o excedente de provisão efetuado pelos bancos comerciais em relação ao mínimo exigido pela regulamentação do Conselho Monetário Nacional Resolução ํำ 2682. 
A Figura 2.5 mostra a composição da provisão para operações de crédito. Em outras palavras, esta figura mostra que a referida provisão pode ser decomposta em duas partes: (i) provisão exigida pela legislação e (ii) provisão excedente, que é a parte que é passível de gerenciamento de resultados.

\subsubsection{Passivos Contingentes}

Os passivos, de maneira geral, são obrigações que a empresa possui. Tais obrigações podem variar quanto a incertezas sobre o tempo ou o valor dos pagamentos que serão exigidos na liquidação. Em outras palavras, existem obrigações em que se conhece o tempo e o valor do pagamento desde o reconhecimento delas - como exemplo, pode-se citar as contas a pagar a fornecedores, que tem valor e data de vencimento previamente acordadas. Por outro lado, existem obrigações, que apesar de certas, não se conhece com exatidão o tempo e o valor em que serão exigidas; estas recebem a denominação de "provisões" - por exemplo, provisão para pagamento de férias: nem o valor nem a data em que serão pagas as férias são conhecidas no momento da constituição, mas podem ser razoavelmente estimados.

"De maneira geral, todas as provisões são contingentes porque são incertas em relação ao tempo ou ao valor. Entretanto, nesta NPC [Norma e Procedimento de Contabilidade], o termo "contingente" é usado para ativos e passivos que não são reconhecidos, pois não atendem aos critérios necessários ao seu reconhecimento. Se os critérios forem atendidos, tem-se um passivo ou um ativo" (IBRACON, NPC 22, item 8). 
Como se pode verificar pela definição de contingência passiva do Instituto Brasileiro dos Auditores Independentes (IBRACON) na mesma NPC sobre "Provisões, Passivos, Contingências Passivas e Contingências Ativas", as contingências passivas assemelham-se às provisões.

“Uma contingência passiva é:

(a) uma possível obrigação presente cuja existência será confirmada somente pela ocorrência ou não de um ou mais eventos futuros, que não estejam totalmente sob o controle da entidade; ou

(b) uma obrigação presente que surge de eventos passados, mas que não é reconhecida porque: (i) é improvável que a entidade tenha de liquidá-la; ou (ii) o valor da obrigação não pode ser mensurado com suficiente segurança" (IBRACON, NPC 22, item 6, viii).

No âmbito dos bancos comerciais e, conseqüentemente, no âmbito deste trabalho, as contingências são usualmente classificadas, dependendo do fato que as originou, em:

- contingências fiscais - normalmente dizem respeito a discussões judiciais a cerca da constitucionalidade ou legalidade de um tributo, a autuações fiscais ou a pedidos de compensação ou restituição de tributos pagos indevidamente;

- contingências trabalhistas - decorrem de discussões judiciais, de autoria de ex-empregados ou sindicatos, sobre o descumprimento de leis trabalhistas;

- contingências cíveis - são decorrentes de discussões judiciais sobre obrigações legais, contratuais e extracontratuais das entidades; por 
exemplo: o pagamento de multas contratuais, o ressarcimento de danos materiais ou a compensação por danos morais;

- contingências administrativas - em razão de discussões, ainda no âmbito administrativo, de penalidades impostas pelas autoridades competentes.

"Para fins de classificação dos ativos e passivos em contingentes ou não, esta NPC usa os termos praticamente certo, provável, possível e remota com os seguintes conceitos:

(a) Praticamente certo - este termo é mais fortemente utilizado no julgamento de contingências ativas. Ele é aplicado para refletir uma situação na qual um evento futuro é certo, apesar de não ocorrido. Essa certeza advém de situações cujo controle está com a administração de uma entidade, e depende apenas dela, ou de situações em que há garantias reais ou decisões judiciais favoráveis, sobre as quais não cabem mais recursos.

(b) Provável - a chance de um ou mais eventos futuros ocorrer é maior do que a de não ocorrer.

(c) Possível - a chance de um ou mais eventos futuros ocorrer é menor que provável, mas maior que remota.

(d) Remota - a chance de um ou mais eventos futuros ocorrer é pequena" (IBRACON, NPC 22, item 9).

"As contingências passivas devem ser reavaliadas periodicamente para determinar se a avaliação anterior continua válida. Se for provável que uma saída de recursos será exigida para um item anteriormente tratado como uma contingência passiva, uma provisão será reconhecida nas 
demonstrações contábeis do período no qual ocorre a mudança na estimativa de probabilidade" (IBRACON, NPC 22, item 24).

"As provisões devem ser reavaliadas em cada data de balanço e ajustadas para refletir a melhor estimativa corrente. Se já não for mais provável que uma saída de recursos será requerida para liquidar a obrigação, a provisão deve ser revertida em contrapartida da linha do balanço elou do resultado contra a qual ela foi originalmente constituída e/ou realizada" (IBRACON, NPC 22, item 44).

O IBRACON também estabeleceu critérios para a divulgação de informações sobre as contingências passivas e suas respectivas provisões, se for o caso.

Tabela 2.3 - Tratamento contábil relativo às contingências passivas

\begin{tabular}{ll}
\hline Classificação da contingência & Tratamento Contábil \\
\hline Praticamente certo & Provisionar \\
\hline Provável e mensurável com suficiente segurança & Provisionar \\
\hline Provável e não mensurável com suficiente segurança & Divulgar \\
\hline Possível & Divulgar \\
\hline Remota & Não divulgar \\
\hline
\end{tabular}

As contingências classificadas como "provável e não mensurável com suficiente segurança", "possível" ou "remota", por não exigirem provisionamento por parte dos bancos comerciais, não serão analisadas no âmbito deste trabalho. Deste modo, a análise deste trabalho estará centrada nas provisões efetuadas pelos bancos comerciais em face de prováveis obrigações - "provável e mensurável com suficiente segurança" e 
"praticamente certo" - que terão que honrar no futuro. A análise será feita com base nos seguintes títulos contábeis:

- Devedores por Depósitos em Garantia (1.8.8.40.00-1), subtítulos Para Interposição de Recursos Fiscais (1.8.8.40.10-4), Para Interposição de Recursos Trabalhistas (1.8.8.40.20-7) e Outros (1.8.8.40.90-8), cuja função é registrar os depósitos decorrentes de exigências legais ou contratuais, inclusive garantias prestadas em dinheiro, tais como os realizados para interposição de recursos em repartições ou juízos e os que garantirem prestação de serviço de qualquer natureza. O subtítulo Para Interposição de Recursos Fiscais deve ser utilizado para registrar os depósitos decorrentes de exigências legais ou contratuais, realizados para interposição de recursos em repartições ou juízos, relativos a impostos e contribuições. O subtítulo Para Interposição de Recursos Trabalhistas deve ser utilizado para registrar os depósitos decorrentes de exigências legais ou contratuais, realizados para interposição de recursos em repartições ou juízos, relativos a causas trabalhistas. O subtítulo Outros deve ser utilizado para registrar outros depósitos decorrentes de exigências legais ou contratuais, realizados para interposição de recursos em repartições ou juízos, assim como os necessários para garantir a prestação de serviços de qualquer natureza;

- Provisão para Riscos Fiscais (4.9.4.50.00-6), subtítulos Impostos e Contribuições sobre Lucros (4.9.4.50.10-9), Impostos e Contribuições sobre Salários (4.9.4.50.20-2) e Outros (4.9.4.50.90-3), cuja função é registrar os valores exigidos da instituição, mas que ainda podem ser objeto de contestação perante à autoridade competente. O subtítulo Impostos e Contribuições sobre Lucros deve ser utilizado para registrar o 
provisionamento de perdas contingentes derivadas de impostos e contribuições incidentes sobre o lucro da instituição ou entidade. O subtítulo Impostos e Contribuições sobre Salários deve ser utilizado para registrar o provisionamento de perdas contingentes derivadas de impostos e contribuições incidentes sobre as despesas de salário da instituição ou entidade. O subtítulo Outros deve ser utilizado para registrar o provisionamento de perdas contingentes derivadas de outros impostos e contribuições;

- Provisão para Passivos Contingentes (4.9.9.35.00-2), subtítulos Passivos Trabalhistas (4.9.9.35.10-5) e Outros Passivos (4.9.9.35.90-9), cuja função é registrar os valores exigidos da instituição, mas que ainda estão em fase de contestação perante à autoridade competente. O subtítulo Passivos Trabalhistas deve ser utilizado para registrar o provisionamento de perdas contingentes derivadas de indenizações trabalhistas. O subtítulo Outros Passivos deve ser utilizado para registrar o provisionamento de outras perdas contingentes da instituição ou entidade. Os valores relativos a obrigações líquidas e certas, não passíveis de contestação, registram-se em “Provisão para Pagamentos a Efetuar (4.9.9.30.00-7)". A provisão para cobertura de riscos fiscais registra-se em "Provisão para Riscos Fiscais (4.9.4.50.00-6)". 


\section{Metodologia da Pesquisa}

\subsection{INTRODUÇÃo}

Para que a pesquisa, que será conduzida com a finalidade de responder o problema proposto por este trabalho - existem indícios suficientes para se afirmar que os bancos comerciais no Brasil praticam alguma modalidade de gerenciamento de resultados? -, possa ser efetivada é necessário que alguns pontos, ainda genéricos, sejam especificados. Tais pontos referem-se à:

- População e plano amostral - critérios de seleção dos elementos da amostra dos principais bancos comerciais brasileiros que será utilizada na pesquisa, detalhando-se os que a comporão;

- Documentos - documentos divulgados pelos bancos comerciais, remetidos ao Banco Central do Brasil em virtude das disposições do COSIF e que foram objeto da pesquisa;

- Período - período que será objeto de análise, apresentando-se algumas limitações impostas pela legislação. 


\subsection{População e Plano Amostral}

Para a execução da análise dos principais bancos comerciais brasileiros, quanto a evidências de gerenciamento de resultados, faz-se necessário que seja definido o critério de seleção utilizado.

O Banco Central do Brasil não faz um ranqueamento específico relativo aos bancos comerciais, apresenta apenas uma classificação geral relativa aos conglomerados bancários. Esta autarquia classifica-os por "Ativo Total menos Intermediação", que corresponde ao somatório das contas de ativo circulante, ativo realizável a longo prazo e ativo permanente - contas "Circulante e Realizável a Longo Prazo" (1.0.0.00.00-7) e "Permanente" (2.0.0.00.00-4) -, deduzida a conta de "Aplicações em Operações Compromissadas - Revendas a Liquidar Posição Financiada" (1.2.1.20.00-2) ${ }^{28}$.

A Tabela 3.1 apresenta informações - Ativo Total (-) Intermediação e Depósito Total (cujos valores acumulados ${ }^{29}$ são apresentados na Figura 3.1), Patrimônio Líquido e Lucro Líquido (cujos valores acumulados são apresentados na Figura 3.2) - sobre os conglomerados bancários brasileiros ${ }^{30}$, relativas à data-base dezembro de 2006. Na referida data-base, segundo 0 Banco Central do Brasil, existiam 104 conglomerados bancários que foram agrupados de dez em dez conglomerados.

\footnotetext{
${ }^{28}$ A composição das colunas do relatório "50 Maiores Bancos e o Consolidado do Sistema Financeiro Nacional" está disponível em: <http://www.bcb.gov.br/fis/TOP50/port/Composicao Contas/ComposicaoResumo.htm>. Acesso em: 19 jul. 2007.

${ }^{29}$ Os conglomerados bancários foram classificados, pelo Banco Central do Brasil, segundo o critério "Ativo Total menos Intermediação".

${ }^{30}$ Consolidado Bancário I: Aglutinado das posições contábeis das instituições bancárias do tipo Conglomerado Bancário I (Conglomerado em cuja composição se verifica pelo menos uma instituição do tipo Banco Comercial ou Banco Múltiplo com Carteira Comercial) e Instituições Bancárias Independentes I (Instituições financeiras do tipo Banco Comercial, Banco Múltiplo com Carteira Comercial ou Caixa Econômica que não integrem conglomerado). Estas informações encontram-se disponíveis em: <http://www.bcb.gov.br/fis/Top50/port/Default.asp? idioma=P>. Acesso em: 19 jul. 2007.
} 
Figura 3.1 - Valores acumulados em dez/2006 (R\$ bilhões)

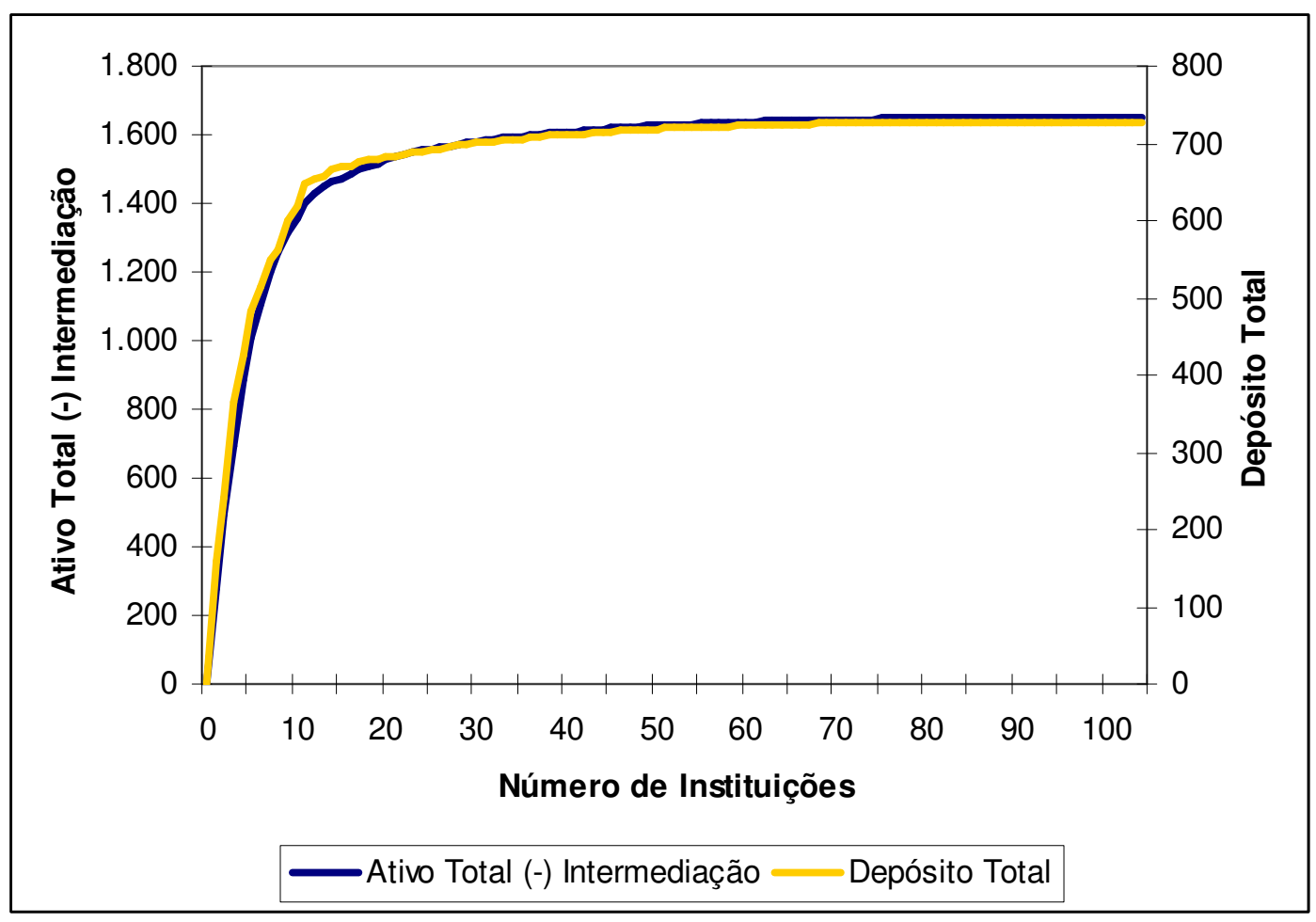

Figura 3.2 - Valores acumulados em dez/2006 (R\$ bilhões)

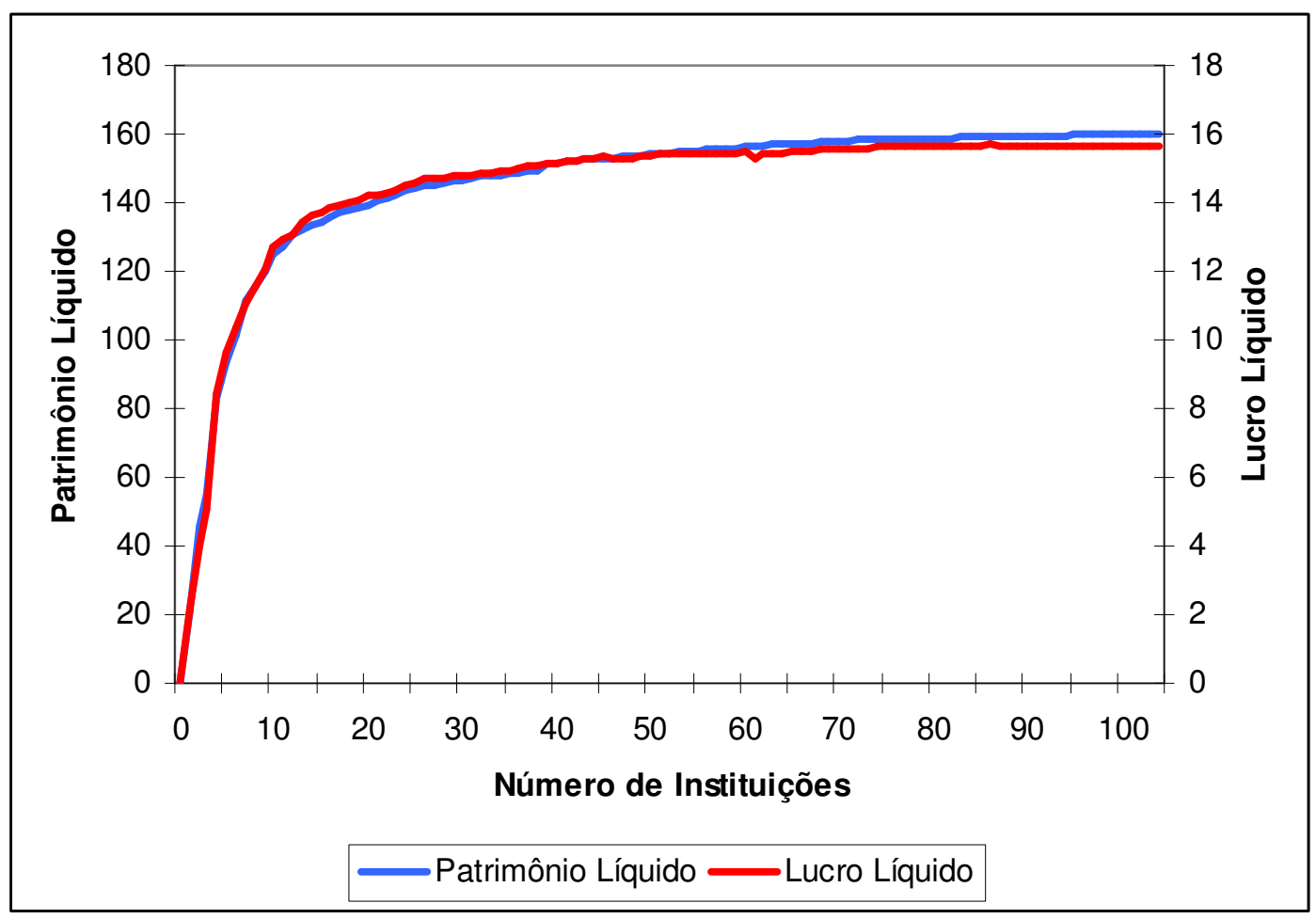


Tabela 3.1 - Conglomerados bancários brasileiros*

\begin{tabular}{|c|c|c|c|c|}
\hline Instituições & $\begin{array}{l}\text { Ativo Total (-) } \\
\text { Intermediação }\end{array}$ & $\begin{array}{r}\text { Patrimônio } \\
\text { Líquido }\end{array}$ & $\begin{array}{r}\text { Lucro } \\
\text { Líquido }\end{array}$ & $\begin{array}{r}\text { Depósito } \\
\text { Total }\end{array}$ \\
\hline \multirow[t]{2}{*}{01 a 10} & 1.359 .645 & 124.853 & 12.734 & 620.169 \\
\hline & $82,3 \%$ & $78,1 \%$ & $81,3 \%$ & $85,2 \%$ \\
\hline \multirow[t]{2}{*}{11 a 20} & 166.161 & 14.579 & 1.474 & 62.380 \\
\hline & $10,1 \%$ & $9,1 \%$ & $9,4 \%$ & $8,6 \%$ \\
\hline \multirow[t]{2}{*}{21 a 30} & 53.423 & 7.320 & 609 & 17.957 \\
\hline & $3,2 \%$ & $4,6 \%$ & $3,9 \%$ & $2,5 \%$ \\
\hline \multirow[t]{2}{*}{31 a 40} & 29.085 & 4.943 & 327 & 10.854 \\
\hline & $1,8 \%$ & $3,1 \%$ & $2,1 \%$ & $1,5 \%$ \\
\hline \multirow[t]{2}{*}{41 a 50} & 18.171 & 2.280 & 242 & 7.204 \\
\hline & $1,1 \%$ & $1,4 \%$ & $1,5 \%$ & $1,0 \%$ \\
\hline \multirow[t]{2}{*}{51 a 60} & 11.349 & 2.228 & 101 & 5.077 \\
\hline & $0,7 \%$ & $1,4 \%$ & $0,6 \%$ & $0,7 \%$ \\
\hline \multirow[t]{2}{*}{61 a 70} & 6.594 & 1.785 & 58 & 1.888 \\
\hline & $0,4 \%$ & $1,1 \%$ & $0,4 \%$ & $0,3 \%$ \\
\hline \multirow[t]{2}{*}{71 a 80} & 3.558 & 822 & 92 & 1.340 \\
\hline & $0,2 \%$ & $0,5 \%$ & $0,6 \%$ & $0,2 \%$ \\
\hline \multirow[t]{2}{*}{81 a 90} & 1.951 & 569 & 7 & 755 \\
\hline & $0,1 \%$ & $0,4 \%$ & $0,0 \%$ & $0,1 \%$ \\
\hline \multirow[t]{2}{*}{91 a 104} & 1.164 & 540 & 15 & 355 \\
\hline & $0,1 \%$ & $0,3 \%$ & $0,1 \%$ & $0,0 \%$ \\
\hline $\begin{array}{c}\text { Total Consolidado } \\
\text { Bancário I }\end{array}$ & 1.651 .102 & 159.920 & 15.660 & 727.978 \\
\hline
\end{tabular}

* Valores em R\$ milhões, em dezembro/2006

Como critério de seleção da amostra a ser utilizada, optou-se por utilizar o maior número possível de conglomerados, sem, contudo, incluir bancos pouco significativos na amostra. Tal cuidado justifica-se, pois este trabalho tem como objetivo verificar se os bancos comerciais utilizam algumas operações selecionadas para gerenciar seus resultados, e a inclusão de bancos pouco significativos poderia distorcer o resultado final obtido, em virtude da heterogeneidade da amostra.

Assim, a amostra selecionada conterá os 20 maiores conglomerados bancários brasileiros na data-base dezembro de 2006. A relação destes conglomerados é apresentada na Tabela 3.2 segundo o critério "Ativo Total menos Intermediação" acima descrito. 
Tabela 3.2 - 20 maiores conglomerados bancários brasileiros*

\begin{tabular}{|c|c|c|c|c|c|}
\hline Ranking & Instituições & $\begin{array}{l}\text { Ativo Total (-) } \\
\text { Intermediação }\end{array}$ & $\begin{array}{r}\text { Patrimônio } \\
\text { Líquido }\end{array}$ & $\begin{array}{r}\text { Lucro } \\
\text { Líquido } \\
\end{array}$ & $\begin{array}{r}\text { Depósito } \\
\text { Total }\end{array}$ \\
\hline 1 & $\mathrm{BB}$ & 281.444 & 20.758 & 2.156 & 158.841 \\
\hline 2 & Bradesco & 210.335 & 24.757 & 1.877 & 83.969 \\
\hline 3 & $\mathrm{CEF}^{\star \star}$ & 200.387 & 9.182 & 1.042 & 121.390 \\
\hline 4 & Itaú & 196.005 & 28.209 & 3.361 & 62.243 \\
\hline 5 & ABN Amro & 116.140 & 10.588 & 1.172 & 55.138 \\
\hline 6 & Santander Banespa & 100.219 & 7.976 & 753 & 31.925 \\
\hline 7 & Unibanco & 92.616 & 10.019 & 714 & 36.370 \\
\hline 8 & Safra & 61.820 & 4.106 & 495 & 12.925 \\
\hline 9 & HSBC & 53.098 & 4.112 & 501 & 37.725 \\
\hline 10 & Votorantim & 47.580 & 5.147 & 664 & 19.641 \\
\hline 11 & Nossa Caixa $^{* *}$ & 39.319 & 2.599 & 164 & 27.566 \\
\hline 12 & Citibank & 30.312 & 3.189 & 204 & 5.559 \\
\hline 13 & UBS Pactual & 17.694 & 1.454 & 333 & 2.621 \\
\hline 14 & Banrisul & 15.597 & 1.294 & 173 & 10.483 \\
\hline 15 & BBM & 12.402 & 665 & 110 & 2.292 \\
\hline 16 & $\mathrm{BNB}^{* *}$ & 12.253 & 1.502 & 126 & 2.648 \\
\hline 17 & Alfa & 11.076 & 1.230 & 86 & 3.804 \\
\hline 18 & BNP Paribas & 9.932 & 916 & 40 & 3.505 \\
\hline 19 & Deutsche & 8.944 & 524 & 118 & 1.108 \\
\hline 20 & Credit Suisse & 8.630 & 1.206 & 121 & 2.794 \\
\hline \multirow{2}{*}{\multicolumn{2}{|c|}{ Total 20 Maiores }} & 1.525 .806 & 139.433 & 14.208 & 682.549 \\
\hline & & $92,4 \%$ & $87,2 \%$ & $90,7 \%$ & $93,8 \%$ \\
\hline \multirow{2}{*}{\multicolumn{2}{|c|}{ Demais 84 Instit./Consolidados }} & 125.297 & 20.487 & 1.452 & 45.430 \\
\hline & & $7,6 \%$ & $12,8 \%$ & $9,3 \%$ & $6,2 \%$ \\
\hline \multicolumn{2}{|c|}{ Total Consolidado Bancário I } & 1.651 .102 & 159.920 & 15.660 & 727.978 \\
\hline
\end{tabular}

A relevância da amostra selecionada é facilmente observável, uma vez que os 20 maiores conglomerados bancários brasileiros possuem participação significativa - 92,4\% do Ativo Total (-) Intermediação, 87,2\% do Patrimônio Líquido, $90,7 \%$ do Lucro Líquido e $93,8 \%$ do Depósito Total - no total consolidado dos conglomerados bancários em cuja composição se verifica pelo menos uma instituição do tipo Banco Comercial ou Banco Múltiplo com Carteira Comercial ou de instituições financeiras do tipo Banco Comercial, Banco Múltiplo com Carteira Comercial ou Caixa Econômica que não integrem 
conglomerado, denominado pelo Banco Central do Brasil como "Consolidado

Bancário l"31.

Mesmo considerando-se o total do Sistema Financeiro Nacional (SFN) ${ }^{32}$, a amostra selecionada ainda é significativamente relevante, pois detém $85,9 \%$ do Ativo Total (-) Intermediação, 80,4\% do Patrimônio Líquido, 78,8\% do Lucro Líquido e 93,2\% do Depósito Total.

\subsection{DOCUMENTOS}

A consolidação das demonstrações financeiras é uma técnica contábil, utilizada em vários países ao redor do mundo, que tem como objetivo permitir que seja conhecida a situação econômico-financeira de um grupo econômico, representado pela empresa controladora e suas empresas controladas ${ }^{33}$.

Para se obter o consolidado, somam-se os saldos de cada conta de todas as empresas do grupo objeto da consolidação, depois são eliminados saldos referentes às transações entre as empresas do grupo. Diante da falta de informações, externamente à empresa controladora, de que está efetivamente

\footnotetext{
31 Definição disponível em: <http://www.bcb.gov.br/fis/Top50/port/Default.asp?idioma=P>. Acesso em: 19 jul. 2007

${ }_{32}$ O Consolidado Bancário I, com 104 instituições, detém 85,9\% do "Ativo Total menos Intermediação" do SFN. Já o Consolidado Bancário II, com 30 instituições, detém apenas 11,7\%. Finalmente, o Consolidado Bancário III (1422 instituições) e o Consolidado Não Bancário (320 instituições), detém, respectivamente, meros 1,6\% e 0,8\%.

33 "Art. 32 - Os componentes do ativo e passivo, as receitas e as despesas das sociedades controladas em conjunto deverão ser agregados às demonstrações contábeis consolidadas de cada investidora, na proporção da participação destas no seu capital social.

$\S 1^{\circ}$ - Considera-se controlada em conjunto aquela em que nenhum acionista exerce, individualmente, os poderes previstos no artigo $3^{\circ}$ desta Instrução.

$\S 2^{\circ}$ - No caso de uma das sociedades investidoras passar a exercer direta ou indiretamente o controle isolado sobre a sociedade controlada em conjunto, a controladora final deverá passar a consolidar integralmente os elementos do seu patrimônio". Conforme a versão consolidada da Instrução CVM no 247, de 27 de março de 1996. Disponível em: <http://www.cvm.gov.br/ asp/cvmwww/atos/exiato.asp?file=linstlinst247consolid.htm>. Acesso em: 19 jul. 2007.
} 
ali registrado, decidiu-se por não utilizar as informações contábeis consolidadas.

Logo, os dados contábeis que serão objeto da análise são os dados referentes aos balancetes individuais dos bancos comerciais. O Banco Central do Brasil, no entanto, em seu relatório "50 Maiores Bancos e o Consolidado do Sistema Financeiro Nacional”34, disponibiliza apenas as informações referentes aos consolidados bancários ${ }^{35}$.

Assim, como a utilização de dados contábeis consolidados não seria interessante no âmbito desta pesquisa, optou-se por utilizar os balancetes individuais das instituições financeiras líderes dos conglomerados ${ }^{36}$, que no caso serão bancos comerciais ou bancos múltiplos com carteira comercial.

A relação das instituições líderes dos conglomerados, as páginas em que tais informações estão disponíveis na internet e algumas outras informações, quer do conglomerado quer da instituição líder, constam do Anexo.

\subsection{PERÍodo}

A Lei nํ 9249, de 26 de dezembro de 1995, revogou a correção monetária das demonstrações financeiras a partir de 1ํ de janeiro de 1996.

\footnotetext{
${ }^{34}$ Disponível em: <http://www.bcb.gov.br/fis/top50/port/default.asp?parmidioma=P\&id=top50>. Acesso em: 19 jul. 2007.

${ }^{35}$ Neste relatório também constam as informações de Instituições Bancárias Independentes, isto é. aquelas instituições financeiras do tipo Banco Comercial, Banco Múltiplo com Carteira Comercial ou Caixa Econômica que não integrem conglomerado bancário.

${ }^{36}$ Obviamente, para os casos de Instituições Bancárias Independentes, foram utilizados os balancetes individuais das próprias instituições financeiras.
} 
"Art. 4 Fica revogada a correção monetária das demonstrações financeiras de que tratam a Lei no 7.799, de 10 de julho de 1989, e o art. 1ํ da Lei no 8.200 , de 28 de junho de 1991.

Parágrafo único. Fica vedada a utilização de qualquer sistema de correção monetária de demonstrações financeiras, inclusive para fins societários.

Art. 35. Esta Lei entra em vigor na data de sua publicação, produzindo efeitos a partir de 1ㅇ de janeiro de 1996".

Deste modo, estabeleceu-se como data inicial para a obtenção das informações contábeis mensais: janeiro de 1996.

A data final escolhida foi a data do último balanço disponível, ou seja, dezembro de 2006.

\subsubsection{Limitações ao Período}

A Circular no 3068, de 8 de novembro de 2001, que estabeleceu critérios para registro e avaliação contábil de títulos e valores mobiliários, começou a produzir efeitos em 31 de março de 2002. Já a Circular no 3082, de 30 de janeiro de 2002, estabeleceu critérios para registro e avaliação contábil de instrumentos financeiros derivativos, começou a produzir efeitos em 30 de junho de 2002. Assim, as análises referentes à operações com títulos e valores mobiliários dar-se-ão para o período de junho de 2002 a dezembro de 2006. 
Com relação às operações de crédito, a Resolução nํㅜ 2682, de 21 de dezembro de 1999, que dispôs sobre critérios de classificação das operações de crédito e regras para constituição de provisão para créditos de liquidação duvidosa, passou a produzir efeitos em 31 de março de 2000. Portanto, os esforços serão concentrados nos períodos em que a referida legislação já se encontrava produzindo efeitos.

Cumpre ressaltar que algumas questões metodológicas específicas relacionadas à análise dos investimentos em controladas e coligadas, das operações com títulos e valores mobiliários, das operações de crédito e dos passivos contingentes, serão detalhadas ao longo da própria análise, no Capítulo 4. 


\section{ANÁlise dos Resultados}

\subsection{INTRODUÇÃo}

A Lei Complementar $n^{\circ}$ 105, de 10 de janeiro de 2001, que dispõe sobre o sigilo das operações de instituições financeiras, determina:

"Art. $1^{\circ}$ As instituições financeiras conservarão sigilo em suas operações ativas e passivas e serviços prestados. (...)

Art. $2^{\circ} \mathrm{O}$ dever de sigilo é extensivo ao Banco Central do Brasil, em relação às operações que realizar e às informações que obtiver no exercício de suas atribuições. (...)

$\S 5^{\circ} \mathrm{O}$ dever de sigilo de que trata esta Lei Complementar estende-se aos órgãos fiscalizadores mencionados no $\S 4^{\circ}$ [o Banco Central do Brasil e a Comissão de Valores Mobiliários] e a seus agentes".

Assim, os resultados e conclusões a serem apresentados neste trabalho não conterão informações que permitam individualizar as análises. Em outras palavras, os resultados e conclusões serão divulgados tendo em vista o 
conjunto das instituições líderes ${ }^{37}$ dos 20 maiores conglomerados bancários brasileiros, nunca sendo divulgadas informações sobre uma única instituição financeira, um pequeno grupo delas, ou de uma forma que permita identificar o banco comercial em questão. Tal precaução justifica-se, pois foram utilizados nas análises dados disponibilizados ao órgão supervisor e que não estão disponíveis ao público em geral, como fora mencionado no item 2.2.

\subsection{InVESTIMENTOS EM CONTROLADAS E ColigADAS}

No COSIF existe o desdobramento de subgrupo Aprovisionamentos e Ajustes Patrimoniais (8.1.8.00.00-9) que, por ser do terceiro nível de detalhamento, é disponibilizado ao público em geral na página do Banco Central do Brasil. No nível seguinte, de uso interno desta autarquia, existem os seguintes títulos contábeis: Despesas de Amortização (8.1.8.10.00-6), Despesas de Depreciação (8.1.8.20.00-3) e Despesas de Provisões Operacionais (8.1.8.30.00-0). Os dois primeiros não possuem subtítulos contábeis, o que não acontece com o último que é bastante analítico, apresentando mais de quinze subtítulos contábeis.

No entanto, como o título contábil Amortização Acumulada do Diferido (2.4.1.99.00-7) registra o valor das amortizações acumuladas (Figura $4.1^{38}$ ), pode-se calcular o valor da amortização mensal pela diferença entre os valores acumulados no mês e no mês anterior. Assim, o valor da amortização dos ágios pagos por investimentos em controladas e coligadas pode ser obtido

\footnotetext{
${ }^{37}$ Neste trabalho serão, basicamente, bancos comerciais ou bancos múltiplos com carteira comercial. A única exceção é a Caixa Econômica Federal.

${ }^{38}$ A Figura 4.1 mostra a amortização acumulada em relação ao total de ágios pagos.
} 
aplicando-se este procedimento ao subtítulo contábil Ágios de Incorporação (2.4.1.99.10-0), da seguinte forma:

\section{AmortMensal $=$ AmortAcum $_{t}-$ AmortAcum $_{t-1}$}

em que:

AmortMensal $=$ valor da amortização mensal dos ágios de incorporação

AmortAcum = saldo acumulado das amortizações mensais dos ágios de incorporação, obtido por meio do subtítulo contábil "Ágios de Incorporação" (2.4.1.99.10-0) do título contábil "Amortização Acumulada do Diferido"

Obtido o valor da amortização mensal (AmortMensal) pela diferença entre os valores acumulados no mês e no mês anterior e confrontando-o com o valor dos ágios pagos nas aquisições de controladas e coligadas - Ágios de Incorporação (2.4.1.10.00-0) -, é possível calcular o tempo em anos que, mantido o valor da amortização mensal, seria necessário para amortizar o ágio dos investimentos em controladas e coligadas (Figura 4.2). Este cálculo pode ser representado por meio da fórmula:

\section{AmortAnos $=($ AmortMensal $/$ Agiolncorp $) / 12^{39}$}

em que:

AmortAnos = número de anos necessários para amortização do ágio

Agiolncorp $=$ valor dos ágios de incorporação pagos na aquisição dos investimentos em controladas ou coligadas, obtido por meio do título contábil "Ágios de Incorporação" (2.4.1.10.00-0)

\footnotetext{
${ }^{39}$ Ao se dividir o valor da amortização mensal pelo total dos ágios pagos, tem-se o tempo em meses que seria necessário para amortizar o ágio dos investimentos em controladas e coligadas. Para obter o tempo em anos, basta dividir este tempo por doze.
} 
Figura 4.1 - Amortização acumulada do ágio em investimentos

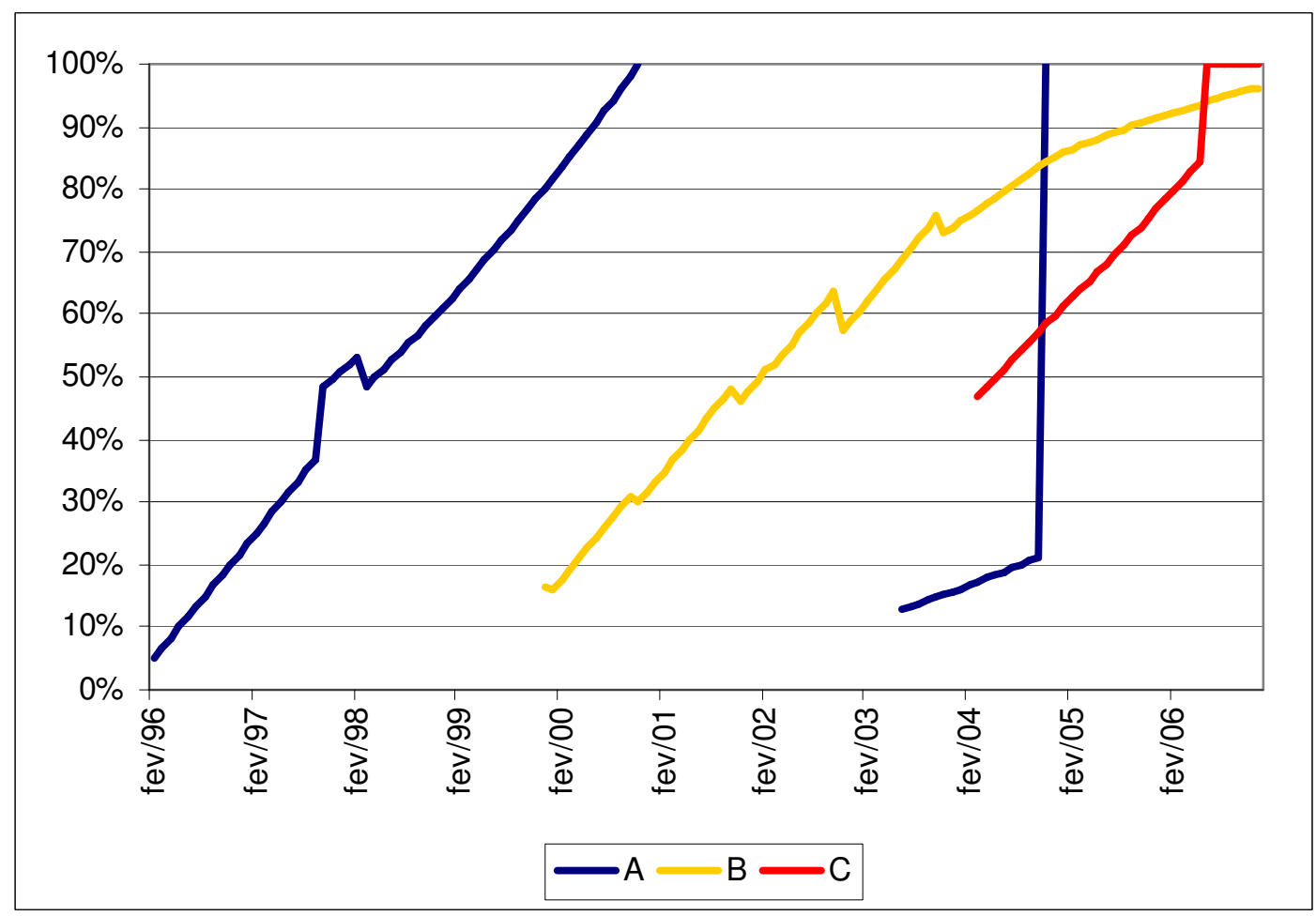

Figura 4.2 - Tempo (anos) da amortização do ágio em investimentos

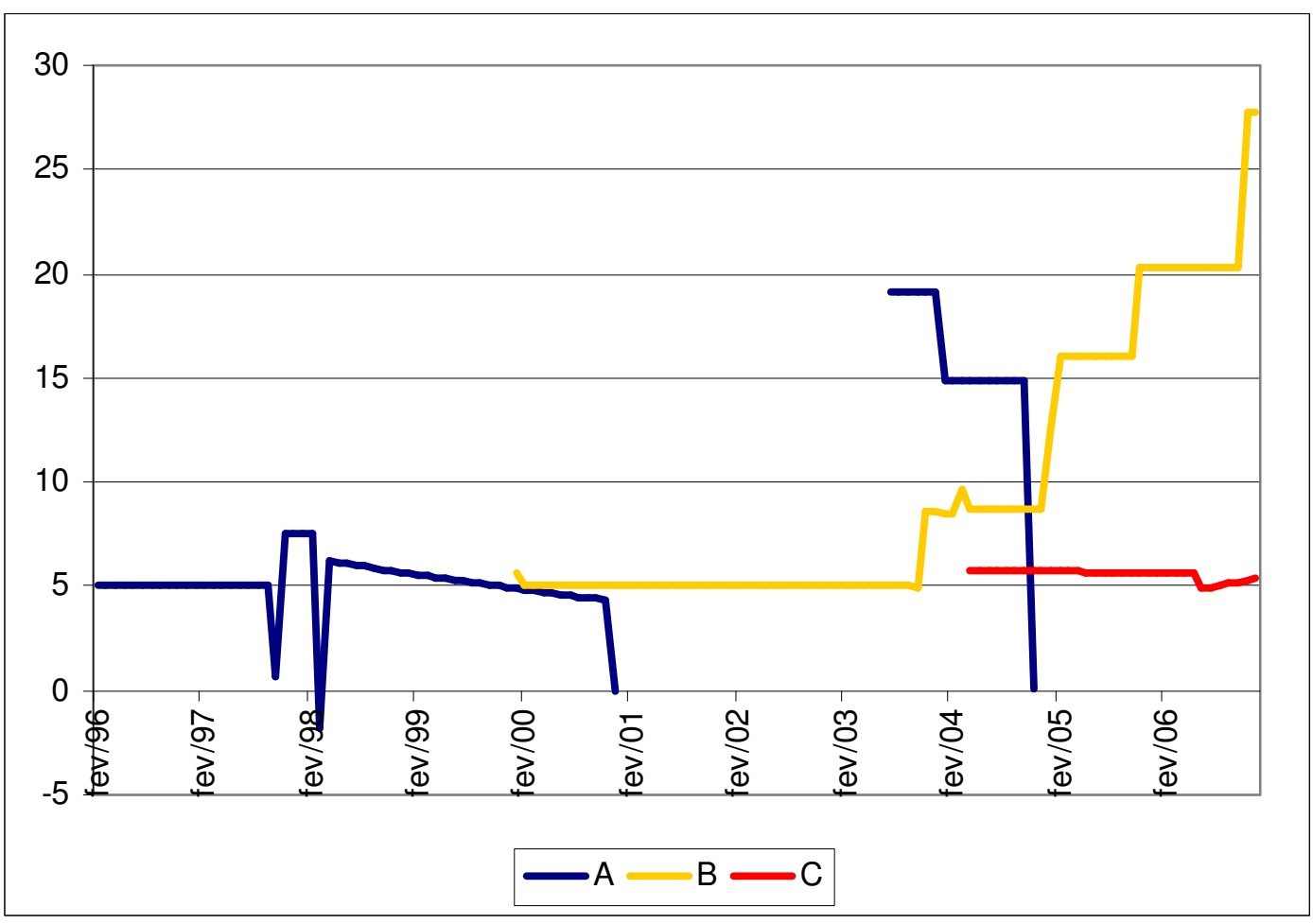


No início dos períodos de amortização, os três bancos analisados, além de não apresentaram variação no valor da amortização mensal, começaram a realizar a amortização mensal já tendo amortizado uma parte substancial do ágio - a Figura 4.1 mostra que o banco $\mathrm{C}^{40}$ começou a amortização do ágio pago tendo já amortizado $46,9 \%$ do valor pago a título de ágio. Deste modo, as variações nos valores da amortização mensal tornam-se pouco representativas em relação ao valor da amortização acumulada, ficando mais difícil a percepção destas variações pelos usuários externos, principalmente, quando não se tem acesso a dados mensais, somente trimestrais ou semestrais.

O banco $A$, nos dois períodos em que apresentou ágio em investimentos - entre 1996 e 2001 e entre 2003 e 2005 -, apresentou valores constantes de ágios pagos em aquisições de investimentos, ou seja, em ambos os períodos os valores relativos a ágio são referentes a uma única aquisição (uma em cada período). As variações ocorridas nos valores mensais de amortização - por exemplo, na situação mais extrema encontrada, em três meses consecutivos, do primeiro para o segundo mês, houve um aumento de $616 \%$, enquanto que do segundo para o terceiro mês, houve uma redução de $91 \%$ do valor amortizado - permitem presumir que, vez por outra, a amortização do ágio em investimentos em controladas ou coligadas foi utilizada para gerenciar os resultados contábeis.

O banco $\mathrm{B}$, durante o período em que manteve o tempo de amortização estabilizado em cinco anos (conforme pode ser observado na Figura 4.2) -

\footnotetext{
${ }^{40} \mathrm{Em}$ virtude do dever de sigilo determinado pela Lei Complementar $\mathrm{n} \times$ 105, de 10 de janeiro de 2001, a ordem e as denominações - banco A, banco B, ..., banco $T$ - apresentados em cada uma das tabelas ou figuras, não guardarão qualquer relação entre si. Em outras palavras, nada indica que o banco $A$ de uma figura ou tabela também seja denominado como banco $A$ em uma outra figura ou tabela.
} 
entre 2000 e 2003 -, aumentou em cinco ocasiões o valor de ágios em investimentos para fazer face aos ágios relativos a novas aquisições de controladas ou coligadas (isto pode ser depreendido das variações observadas, no mesmo período, no percentual da amortização acumulada em relação ao total do ágio pago - Figura 4.1). No período seguinte - do final de 2003 ao final de 2006 -, apesar do valor dos ágios estarem absolutamente estáveis, isto é, ou não foi feita nenhuma aquisição no período ou não foi pago ágio para nenhuma aquisição feita no período, o valor da amortização mensal sofreu sucessivas reduções, chegando a representar apenas $30,6 \%$ do valor que era feito no início deste período. Os sucessivos aumentos no tempo da amortização do ágio em investimentos (Figura 4.2) resulta no comportamento praticamente assintótico da amortização acumulada (Figura 4.1).

Caso, no final de 2003 - ocasião em que o banco B começou a reduzir as amortizações mensais dos ágios em investimentos -, fosse mantido o valor mensal da amortização, o saldo restante do ágio seria totalmente amortizado em 17 meses. No entanto, em virtude das sucessivas reduções no valor da amortização mensal, ao final de 38 meses (última data analisada: dezembro de 2006), se fosse mantido o valor então praticado, o ágio restante ainda necessitaria de mais 12 meses para ser totalmente amortizado. Diante disso, pode-se presumir que $\mathrm{O}$ banco $\mathrm{B}$ também utilizou as contas relativas a amortização de ágio em investimentos em controladas e coligadas para gerenciar os resultados contábeis.

O banco $\mathrm{C}$ apresentou o tempo de amortização praticamente estável, apesar de terem havido algumas pequenas alterações no valor mensal da amortização. Entretanto, no final do período de análise, o valor dos ágios em 
investimentos passou a aumentar todos os meses (entre 1,57\% e 1,71\%), como se fosse feita uma nova aquisição por mês. A amortização acumulada passou a registrar sempre $100 \%$ do valor registrado como ágio. Esta forma de contabilização sugere que este banco deveria ser investigado mais a fundo, sem, contudo, permitir afirmar que as contas relativas a amortização de ágio tenham sido utilizadas para gerenciamento de resultados.

Os demais dezessete bancos comerciais não registraram valores relativos a ágios de investimentos em controladas e coligadas nas instituições financeiras líderes dos conglomerados.

O coeficiente de correlação de Pearson ( $r$ ) é a medida do grau de associação entre duas características a partir de uma série de observações, ou seja, a medida do grau de associação da relação linear entre duas variáveis, que é dado pela expressão:

$$
r(x, y)=\frac{\sum(x-\bar{x})(y-\bar{y})}{\sqrt{\sum(x-\bar{x})^{2} \sum(y-\bar{y})^{2}}}
$$

O coeficiente de correlação de Pearson deve ser interpretado da seguinte forma:

- $r=1$ - indica uma correlação positiva perfeita entre as duas variáveis, que as variáveis são diretamente proporcionais;

- $r=-1$ - indica uma correlação negativa perfeita entre as duas variáveis, que as variáveis são inversamente proporcionais, isto é, na mesma proporção que uma variável aumenta a outra variável diminui; 
- $r=0$ - indica que as duas variáveis não dependem linearmente uma da outra. Pode haver dependência não-linear entre as variáveis.

A Tabela 4.1 mostra o coeficiente de correlação entre o valor do ágio de incorporação e as respectivas amortizações mensais.

Tabela 4.1 - Correlação entre ágio de incorporação e amortização mensal

\begin{tabular}{ccc}
\hline Banco & $\begin{array}{c}\text { Coeficiente } \\
\text { de Correlação }\end{array}$ & $\begin{array}{c}\text { Número de } \\
\text { Observações }\end{array}$ \\
\hline A - período 1 & 0,0000 & 58 \\
\hline A - período 2 & $-0,0000$ & 17 \\
\hline B & $-0,5036$ & 84 \\
\hline C & $-0,3287$ & 33 \\
\hline
\end{tabular}

Analisando a teoria contábil que embasa a ativação dos ágios pagos na aquisição de investimentos e a conseqüente amortização destes valores, espera-se obter uma forte correlação positiva ${ }^{41}$ entre eles.

O banco $\mathrm{A}$ apresentou coeficientes estatisticamente iguais a zero ${ }^{42}$, que indica não haver dependência linear entre as variáveis, confirmando os indícios apresentados. No caso do banco B, o coeficiente de Pearson indica haver uma moderada correlação negativa entre as variáveis, reforçando, assim, os indícios de que o banco utiliza as contas relativas ao ágio de incorporação para gerenciar seus resultados. Finalmente, o banco C, apesar da inspeção dos valores não apontar para gerenciamento de resultados, apresentou coeficiente de correlação negativo. $O$ valor de $-0,33$ para aquele coeficiente sugere que a

\footnotetext{
${ }^{41}$ Alguns autores sugerem que coeficientes de correlação de Pearson, em valores absolutos, superiores a 0,7 indicam forte correlação entre as variáveis e que se estes forem superiores a 0,9 haveria uma correlação muito forte.

${ }_{42}$ Os dígitos significativos apareceram apenas na décima sétima casa decimal, tanto no período $1(0,0000000000000000861131)$ quanto no período $2(0,0000000000000000265356)$.
} 
correlação negativa é fraca, contudo esperava-se uma correlação positiva forte, indicando que o banco contabiliza os ágios de incorporação de maneira diferente do esperado.

Caso fosse calculado o coeficiente de Pearson para os valores iniciais das séries ${ }^{43}$, no caso dos bancos B e C este valor seria $0,9927^{44}$ e $0,9258^{45}$, respectivamente. Estes dados reforçam a posição de que os bancos passaram a gerenciar seus resultados e a contabilizar de forma não aderente aos princípios contábeis geralmente aceitos.

Conclui-se, então, que existem indícios de que 10\% dos bancos comerciais analisados utilizaram os investimentos em controladas e coligadas para gerenciar seus resultados. No entanto, o resultado obtido é significativamente maior - dois em três bancos - se forem considerados apenas os bancos comerciais que registraram valores relativos a ágios investimentos em controladas e coligadas nas instituições financeiras líderes dos conglomerados. Não se pode afirmar que $66 \%$ dos bancos comerciais utilizam os investimentos em controladas e coligadas para gerenciar seus resultados, pois a amostra, neste caso apenas três bancos, foi muito pequena.

\footnotetext{
${ }^{43}$ Como mencionado anteriormente, o banco $\mathrm{A}$ "apresentou valores constantes de ágios pagos em aquisições de investimentos, ou seja, em ambos os períodos os valores relativos a ágio são referentes a uma única aquisição (uma em cada período)". Uma vez que os valores de uma das variáveis é constante, é impossível calcular o coeficiente de correlação, pois chega-se a uma divisão por zero.

${ }^{44}$ A série completa tem 84 observações e esta série inicial, até que o gerenciamento de resultados efetivamente começasse, possui 46 observações.

${ }^{45}$ A série completa tem 33 observações e esta série inicial, até que o gerenciamento de resultados efetivamente começasse, possui 26 observações.
} 


\subsection{Operações com títulos e Valores Mobiliários}

Os bancos comerciais precisam manter o registro, em contas de compensação - no nível de títulos contábeis (quarto nível) -, do volume de títulos e valores mobiliários que mantém classificados como: Títulos para Negociação (3.0.3.30.00-1), Títulos Disponíveis para Venda (3.0.3.40.00-8) e Títulos Mantidos até o Vencimento (3.0.3.50.00-5). Ciente de que cada título deve ser classificado numa destas três categorias ${ }^{46}$, é possível calcular o total de títulos em carteira e o percentual mantido em cada categoria pelos bancos comerciais, conforme:

\section{TotalTVM = TVMNeg + TVMDisp + TVMMant \\ PercNeg $=$ TVMNeg $/$ TotalTVM \\ PercDisp $=$ TVMDisp $/$ TotalTVM \\ PercMant $=$ TVMMant $/$ TotalTVM}

em que:

TotalTVM = volume total de títulos e valores mobiliários

TVMNeg = volume de títulos e valores mobiliários classificados, pelo banco comercial, na categoria "Títulos para Negociação" (3.0.3.30.00-1)

TVMDisp = volume de títulos e valores mobiliários classificados, pelo banco comercial, na categoria "Títulos Disponíveis para Venda" (3.0.3.40.00-8)

TVMMant = volume de títulos e valores mobiliários classificados, pelo banco comercial, na categoria "Títulos Mantidos até o Vencimento" (3.0.3.50.00-5) PercNeg $=$ percentual da carteira de títulos e valores mobiliários classificados na categoria "Títulos para Negociação" PercDisp = percentual da carteira de títulos e valores mobiliários classificados na categoria "Títulos Disponíveis para Venda"

\footnotetext{
${ }^{46}$ Conforme determinado pela Circular no 3068, de 8 de novembro de 2001.
} 
PercMant $=$ percentual da carteira de títulos e valores mobiliários classificados na categoria "Títulos Mantidos até o Vencimento"

Dois bancos comerciais classificaram todos os títulos adquiridos no período analisado na categoria "Títulos para Negociação". Um terceiro banco, por sua vez, somente utilizou a categoria "Títulos Disponíveis para Venda". Estes três bancos nunca alteraram a classificação de um título mantido em carteira, logo não utilizaram as operações com títulos e valores mobiliários para gerenciar seus resultados. Assim, serão excluídos das análises.

Para os demais dezessete bancos, é interessante determinar a importância de cada categoria em relação à carteira de títulos e valores mobiliários do banco. Se os percentuais mantidos em carteira por determinado banco comercial em cada uma das três categorias fosse colocado num gráfico de área, obter-se-ia algo semelhante ao exemplo da Figura 4.3.

Figura 4.3 - Exemplo da importância de cada categoria

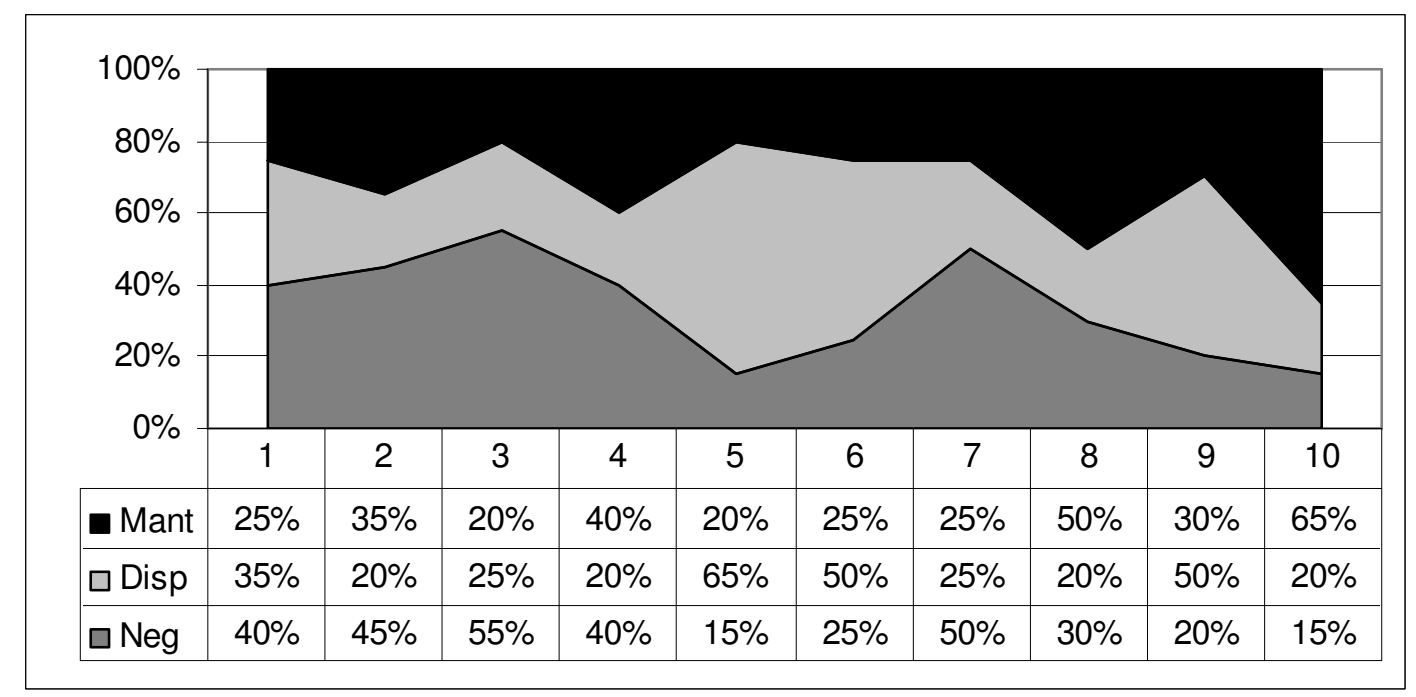


No exemplo da Figura 4.3, dada a grande variabilidade dos percentuais mantidos em cada categoria ao longo do tempo - note que no exemplo há somente 10 períodos, enquanto os dados que serão analisados referem-se a 55 períodos - e a não preponderância de uma categoria, poder-se-ia utilizar como medida desta importância uma estimativa da área de cada uma das três categorias.

A área total do gráfico é dada pela multiplicação da base - número de períodos - pela altura - somatório das três categorias em determinado período. Assim, tal área equivaleria a $1000 \%$ (10 períodos x 100\%). Somando-se os percentuais mantidos em cada categoria, como exposto abaixo, obter-se-ia uma estimativa desta importância:

$$
\text { ImpCat }=\sum_{i=1}^{n} \text { PercCat }_{i}
$$

em que:

ImpCat = importância de determinada categoria na carteira de títulos e valores mobiliários do banco comercial: para negociação (ImpNeg), disponível para venda (ImpDisp) ou mantido até o vencimento (ImpMant) PercCat $=$ percentual da carteira de títulos e valores mobiliários classificados em determinada categoria (PercNeg, PercDisp ou PercMant)

n = número de períodos

No exemplo proposto, a importância de cada categoria é: títulos para negociação de 335\%; títulos disponíveis para a venda de 330\%; títulos mantidos até o vencimento de 335\%. O somatório das importâncias das três categorias é igual à área total do gráfico (1000\%). 
A Tabela 4.2 mostra a importância de cada categoria para os dezessete bancos comerciais que foram objeto de análise. A tabela é apresentada em ordem decrescente de importância da categoria dos títulos mantidos até o vencimento.

Tabela 4.2 - Importância das categorias na carteira de títulos

\begin{tabular}{rrrrr}
\hline IF & ImpNeg $^{47}$ & ImpDisp $^{48}$ & ImpMant $^{49}$ & Total $^{50}$ \\
\hline $\mathrm{A}$ & $1528 \%$ & $537 \%$ & $3434 \%$ & $5500 \%$ \\
\hline $\mathrm{B}$ & $323 \%$ & $1926 \%$ & $3250 \%$ & $5500 \%$ \\
\hline $\mathrm{C}$ & $1678 \%$ & $576 \%$ & $3246 \%$ & $5500 \%$ \\
\hline $\mathrm{D}$ & $2379 \%$ & $16 \%$ & $3105 \%$ & $5500 \%$ \\
\hline $\mathrm{E}$ & $560 \%$ & $2908 \%$ & $2032 \%$ & $5500 \%$ \\
\hline $\mathrm{F}$ & $1631 \%$ & $1871 \%$ & $1998 \%$ & $5500 \%$ \\
\hline $\mathrm{G}$ & $1582 \%$ & $2552 \%$ & $1365 \%$ & $5500 \%$ \\
\hline $\mathrm{H}$ & $2832 \%$ & $1413 \%$ & $1254 \%$ & $5500 \%$ \\
\hline $\mathrm{I}$ & $532 \%$ & $3971 \%$ & $997 \%$ & $5500 \%$ \\
\hline $\mathrm{J}$ & $3181 \%$ & $1781 \%$ & $538 \%$ & $5500 \%$ \\
\hline $\mathrm{K}$ & $3242 \%$ & $1739 \%$ & $519 \%$ & $5500 \%$ \\
\hline $\mathrm{L}$ & $5053 \%$ & $85 \%$ & $362 \%$ & $5500 \%$ \\
\hline $\mathrm{M}$ & $435 \%$ & $4762 \%$ & $303 \%$ & $5500 \%$ \\
\hline $\mathrm{N}$ & $4317 \%$ & $1156 \%$ & $27 \%$ & $5500 \%$ \\
\hline $\mathrm{O}$ & $2751 \%$ & $2749 \%$ & $0 \%$ & $5500 \%$ \\
\hline $\mathrm{P}$ & $3021 \%$ & $2479 \%$ & $0 \%$ & $5500 \%$ \\
\hline $\mathrm{Q}$ & $4583 \%$ & $917 \%$ & $0 \%$ & $5500 \%$ \\
\hline
\end{tabular}

Os títulos mantidos até o vencimento devem estar registrados por um valor teórico que reflita a apropriação dos rendimentos segundo a relação do tempo decorrido desde sua aquisição e o período até seu vencimento. No jargão do mercado financeiro, estes títulos devem seguir a "curva do papel". Deste modo, bancos comerciais que apresentam um percentual elevado de

\footnotetext{
${ }^{47}$ Importância da categoria dos títulos para negociação na carteira de títulos do banco.

${ }^{48}$ Importância da categoria dos títulos disponíveis para a venda na carteira de títulos do banco.

${ }^{49}$ Importância da categoria dos títulos mantidos até o vencimento na carteira de títulos do banco.

${ }^{50}$ Dois bancos apresentaram informações para um número menor de períodos, porém os dados foram ajustados proporcionalmente para que as informações relativas a estes bancos pudessem ser comparadas com as informações dos demais bancos.
} 
títulos classificados nesta categoria teriam, a priori, menor possibilidade de gerenciar seus resultados.

Em contrapartida, os bancos comerciais, ao decidirem classificar os títulos e valores mobiliários na categoria títulos para negociação ou na categoria títulos disponíveis para venda, decidem, indiretamente, se os ganhos ou perdas relativos aos ajustes dos títulos e valores mobiliários ao valor de mercado transitarão imediata ${ }^{51}$ ou mediatamente - quando de sua efetiva realização - no resultado do período. Logo, carteiras com percentuais significativos de títulos para negociação ou títulos disponíveis para venda, associadas a alta variabilidade destes percentuais indicaria maior possibilidade de gerenciamento de resultados.

Assim, inicialmente, os dezessete bancos comerciais - objeto das análises relativas a títulos e valores mobiliários - foram divididos em cinco grupos de acordo com a importância dos títulos mantidos até o vencimento na carteira destes bancos (conforme apresentado na Tabela 4.3), uma vez que a quantidade destes títulos pode ser fundamental para determinar a utilização das operações com títulos e valores mobiliários para gerenciar os resultados.

Tabela 4.3 - Grupos para análises relativas a TVM

\begin{tabular}{cc}
\hline Bancos comerciais & $\begin{array}{c}\text { Percentual dos títulos } \\
\text { mantidos até o vencimento }\end{array}$ \\
\hline $\mathrm{A}, \mathrm{B}, \mathrm{C} \mathrm{e} \mathrm{D}$ & entre $56 \%$ e $63 \%$ \\
\hline $\mathrm{E} \mathrm{e} \mathrm{F}$ & entre $36 \%$ e $37 \%$ \\
\hline $\mathrm{G}, \mathrm{He} \mathrm{l}$ & entre $18 \%$ e $25 \%$ \\
\hline $\mathrm{J}, \mathrm{K}, \mathrm{L}$ e M & entre $5 \%$ e $10 \%$ \\
\hline $\mathrm{N}, \mathrm{O}, \mathrm{P} \mathrm{e} \mathrm{Q}$ & menos de $1 \%$ \\
\hline
\end{tabular}

\footnotetext{
${ }^{51}$ A contrapartida dos ajustes a valor de mercado dos títulos para negociação é uma conta de resultado, enquanto que a contrapartida dos ajustes a valor de mercado dos títulos disponíveis é uma conta do patrimônio líquido.
} 
Para a identificação de indícios de gerenciamento de resultados tal divisão mostrou-se infrutífera. Os bancos foram, então, agrupados por comportamentos semelhantes, ao longo do tempo, na administração da carteira de títulos e valores mobiliários.

Figura 4.4 - Composição da carteira do banco $L$

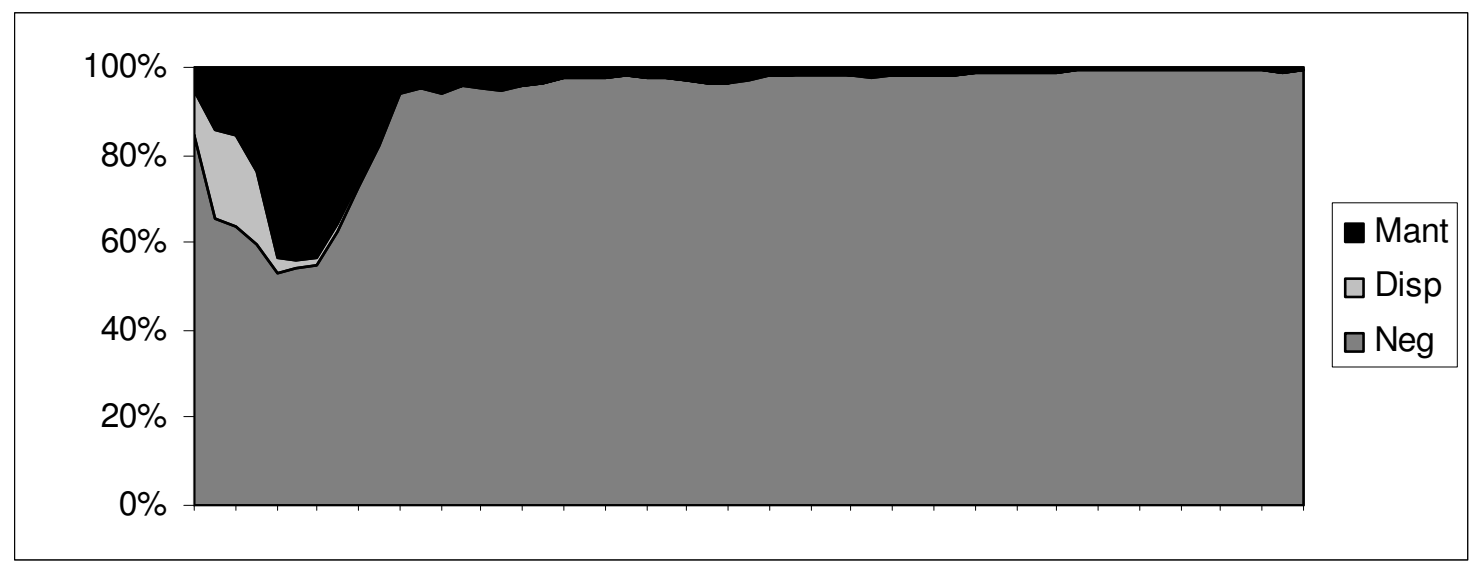

O banco $\mathrm{L}^{52}$ utilizou significativamente as três categorias somente durante os primeiros doze meses, ou seja, até maio de $2003^{53}$ (Figura 4.4). Nos meses seguintes, por ter classificado praticamente todos os títulos na categoria títulos para negociação, não se pode falar que este banco tenha gerenciado resultados utilizando as operações com títulos e valores mobiliários.

Os bancos $A, C$ e $D$ classificaram uma quantidade pequena e praticamente constante na categoria títulos disponíveis para a venda, conforme pode ser observados nas Figuras 4.5, 4.6 e 4.7.

\footnotetext{
${ }^{52} \mathrm{Em}$ virtude do dever de sigilo determinado pela Lei Complementar $\mathrm{n} \times$ 105, de 10 de janeiro de 2001, a ordem e as denominações - banco A, banco B, ..., banco $T$ - apresentados em cada uma das tabelas ou figuras, não guardarão qualquer relação entre si.

${ }^{53}$ A omissão das informações relativas ao período de tempo (eixo das abscissas) foi feita propositalmente para que a identificação dos bancos não fosse possível.
} 
Figura 4.5 - Composição da carteira do banco $A$

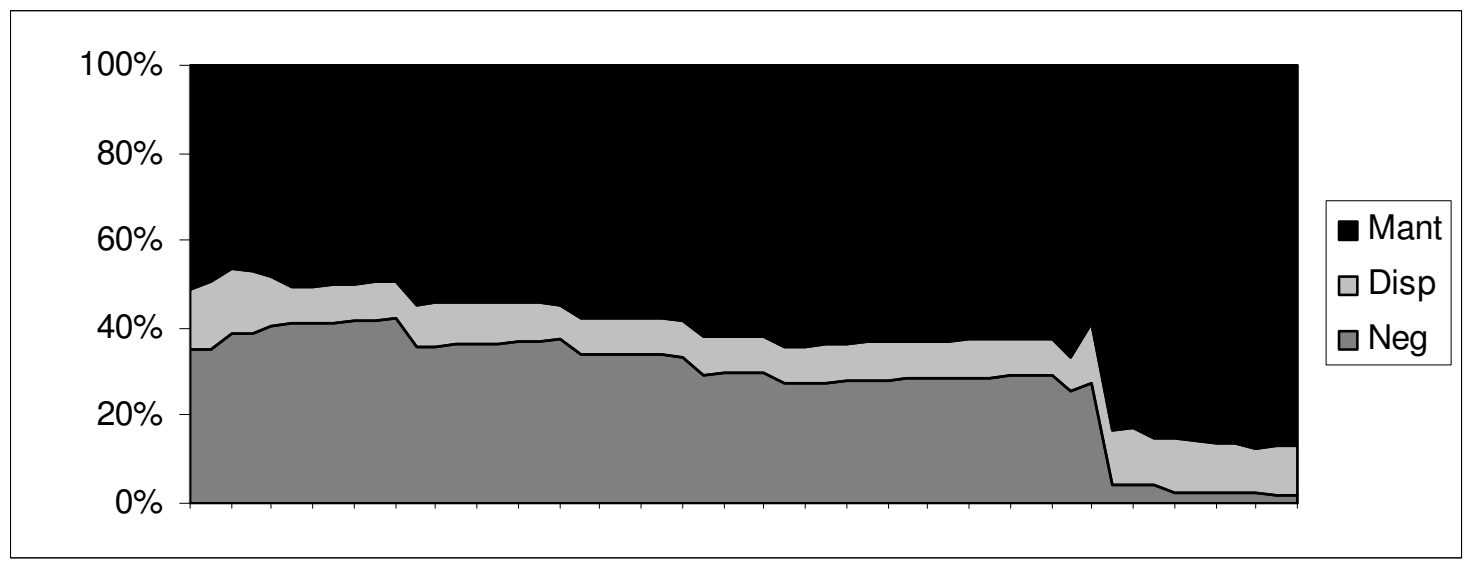

Figura 4.6 - Composição da carteira do banco $C$

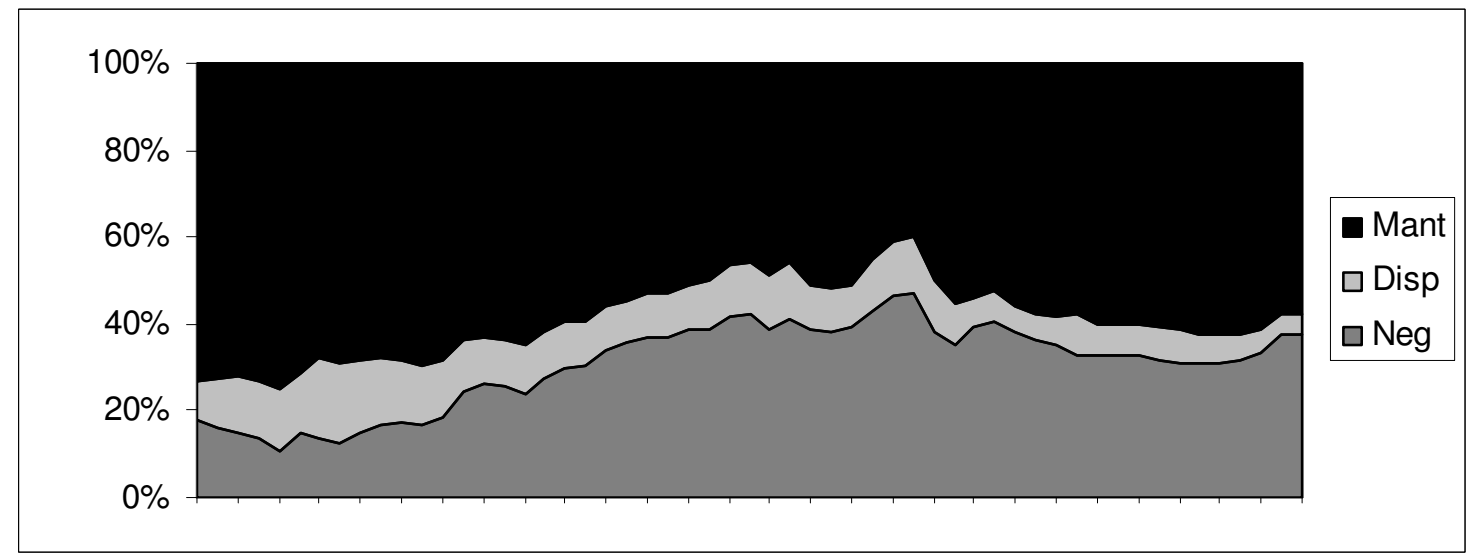

Figura 4.7 - Composição da carteira do banco $D$

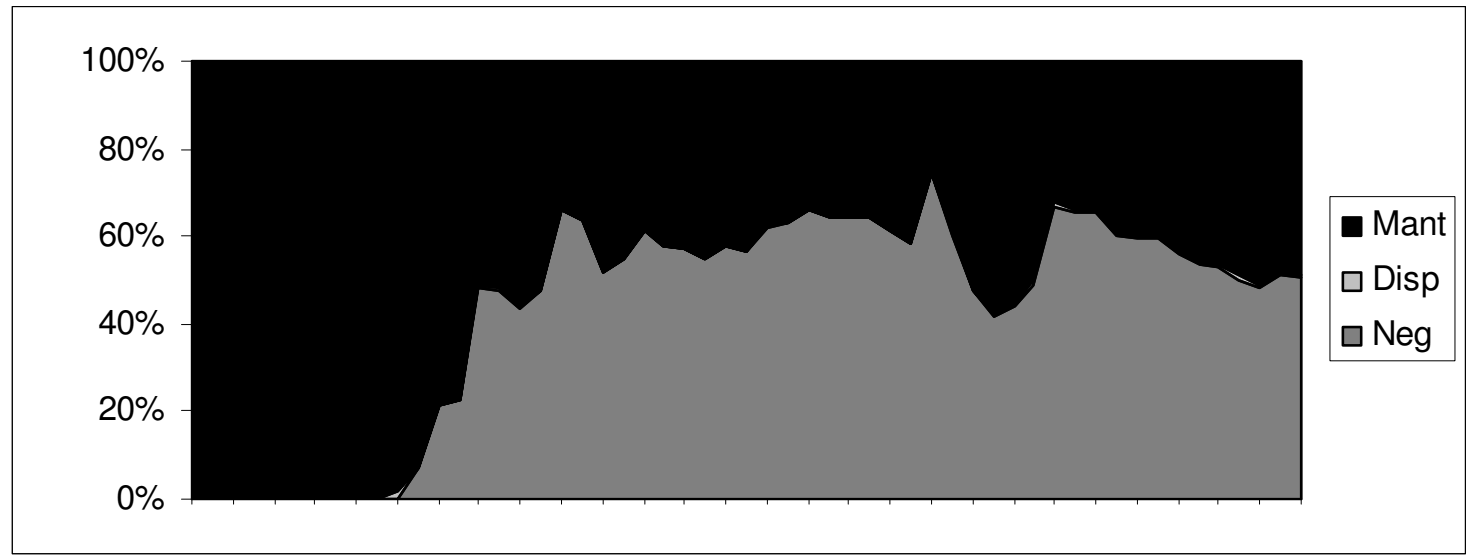


$\mathrm{Na}$ Tabela 4.4 estão relacionados os coeficientes de correlação de Pearson para as categorias de títulos e valores mobiliários, duas a duas.

Tabela 4.4 - Correlação entre os percentuais de TVM em carteira (1)

\begin{tabular}{cccc}
\hline IF & $\begin{array}{c}\text { Correlação } \\
\text { Neg x Disp }\end{array}$ & $\begin{array}{c}\text { Correlação } \\
\text { Disp x Mant }\end{array}$ & $\begin{array}{c}\text { Correlação } \\
\text { Mant x Neg }\end{array}$ \\
\hline A & $-0,3482$ & 0,2026 & $-0,9885$ \\
\hline C & $-0,5231$ & 0,2194 & $-0,9463$ \\
\hline D & 0,1667 & $-0,1816$ & $-0,9999$ \\
\hline B & $-0,3766$ & $-0,9359$ & 0,0261 \\
\hline F & 0,1796 & $-0,7679$ & $-0,7681$ \\
\hline
\end{tabular}

Como observado anteriormente, os bancos $A, C$ e $D$ mantiveram uma quantidade pequena e praticamente constante na categoria títulos disponíveis para a venda, o que explica as fortes correlações observadas entre títulos mantidos até o vencimento e títulos para negociação.

Principalmente os bancos C e D apresentaram muitas variações nos percentuais de cada categoria. Contudo, no âmbito deste trabalho, estas variações não foram consideradas como indícios de gerenciamento de resultado, pois as instituições financeiras que desejem manter até o vencimento títulos e valores mobiliários em carteira, precisam demonstrar capacidade financeira para tal.

“[Art. 1] Parágrafo 3 - Na categoria títulos mantidos até o vencimento, devem ser registrados os títulos e valores mobiliários, exceto ações não resgatáveis, para os quais haja intenção e capacidade financeira da instituição de mantê-los em carteira até o vencimento. 
[Art. 1ํ] Parágrafo $4^{\circ}-A$ capacidade financeira de que trata o parágrafo anterior deve ser caracterizada pela disponibilidade de recursos de terceiros, exceto dívidas subordinadas e instrumentos híbridos de capital e dívida elegíveis a capital, nos termos da Resolução 2.837, de 30 de maio de 2001, referenciados na mesma moeda e com prazo igual ou superior ao dos correspondentes títulos.

Art. $8^{\circ}$ - Adicionalmente às informações mínimas requeridas no artigo anterior, deve ser divulgada, no relatório da administração, declaração sobre a capacidade financeira e a intenção de a instituição manter até $o$ vencimento os títulos classificados na categoria títulos mantidos até o vencimento." (Circular no 3068).

Os bancos B e F (Figuras 4.8 e 4.9) foram agrupados, pois no início do período analisado classificavam a maior parte os títulos em carteira na categoria títulos mantidos até o vencimento. Num segundo momento, que em ambos os bancos foi muito breve, houve a predominância dos títulos para negociação. Finalmente, no final do período, decidiram concentrar a classificação nos títulos disponíveis para a venda, sendo que o banco B mantém, praticamente, apenas títulos nesta categoria.

As alterações na composição das carteiras destes bancos foram muitas e em algumas ocasiões elas foram bastante intensas. Contudo, as correlações mais fortes, indicadas pelos coeficientes de Pearson (Tabela 4.4), sempre envolveram títulos mantidos até o vencimento. Assim, estas alterações foram consideradas como mudança de política, não como gerenciamento de resultados. 
Figura 4.8 - Composição da carteira do banco $B$

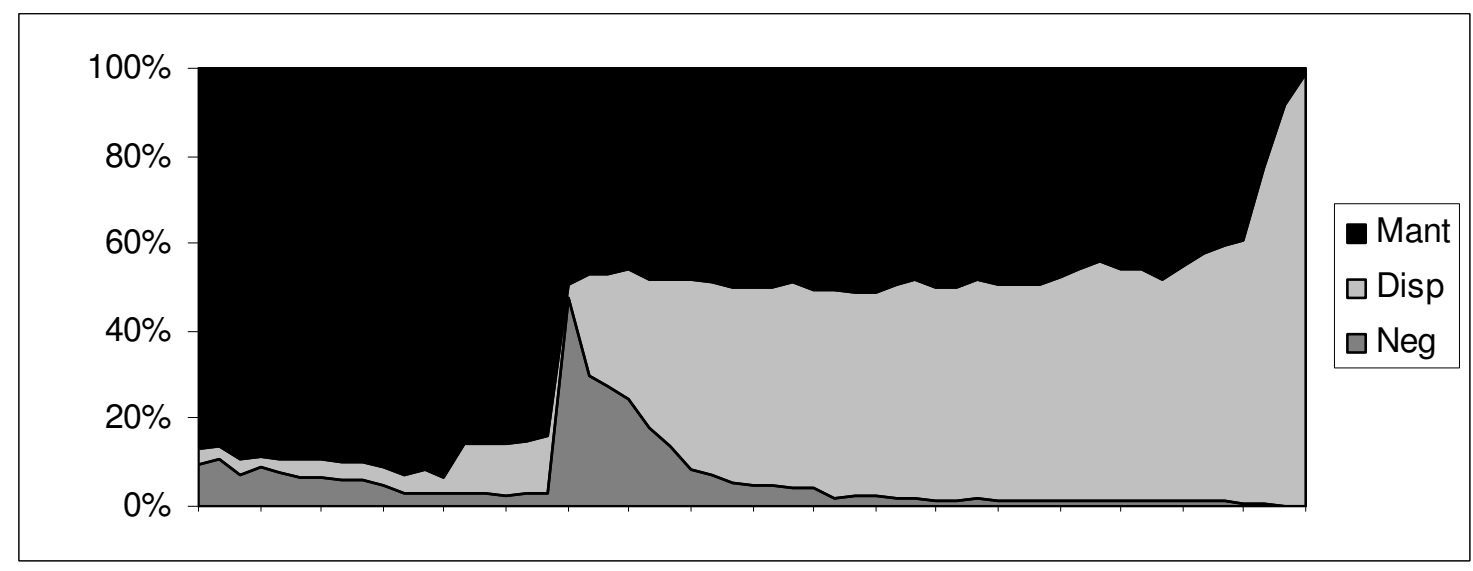

Figura 4.9 - Composição da carteira do banco $F$

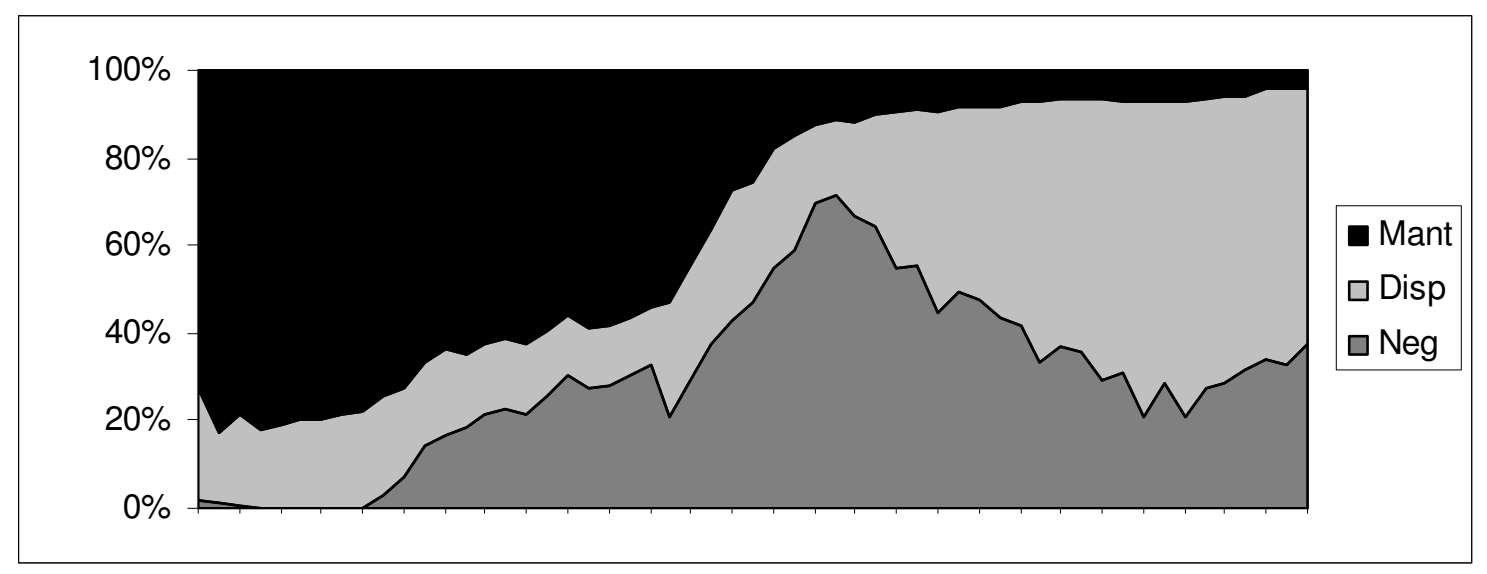

O grupo composto pelos bancos comerciais $\mathrm{E}, \mathrm{I}, \mathrm{M}, \mathrm{N}$ e $\mathrm{Q}$, apresentou comportamento semelhante no que se refere às variações observadas na composição da carteira. Estas variações foram poucas, porém muito bruscas.

São exemplos destas variações muito bruscas: (i) o banco $Q$, ainda em 2002, apresentou variação superior a $80 \%$ nos percentuais dos títulos para negociação e dos títulos disponíveis para a venda; (ii) o banco M, em 2004, por sua vez, mostrou duas variações sucessivas em torno de $70 \%$ carteira nestas mesmas categorias. A variação ocorrida no banco $Q$ deveu-se a uma venda de 
mais de $90 \%$ da carteira de títulos e valores mobiliários, que somente foi recomposta após a publicação do balanço patrimonial seguinte. No caso do banco M, houve um expressivo aumento de $120 \%$ na carteira num mês, sendo toda ela registrada na categoria títulos para negociação; no mês seguinte, depois da publicação do balanço, valores semelhantes foram retirados desta categoria e registrados na categoria títulos disponíveis para a venda, enquanto a variação na carteira total de títulos foi inferior a $1 \%$.

Figura 4.10 - Composição da carteira do banco $E$

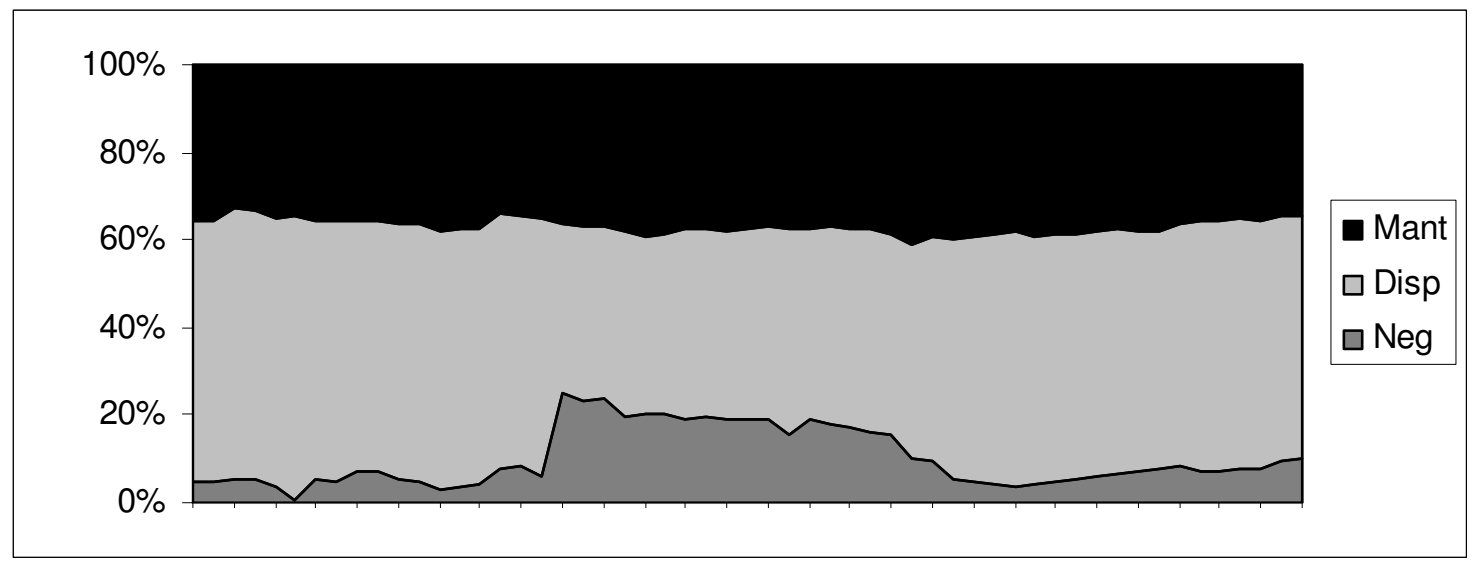

Figura 4.11 - Composição da carteira do banco I

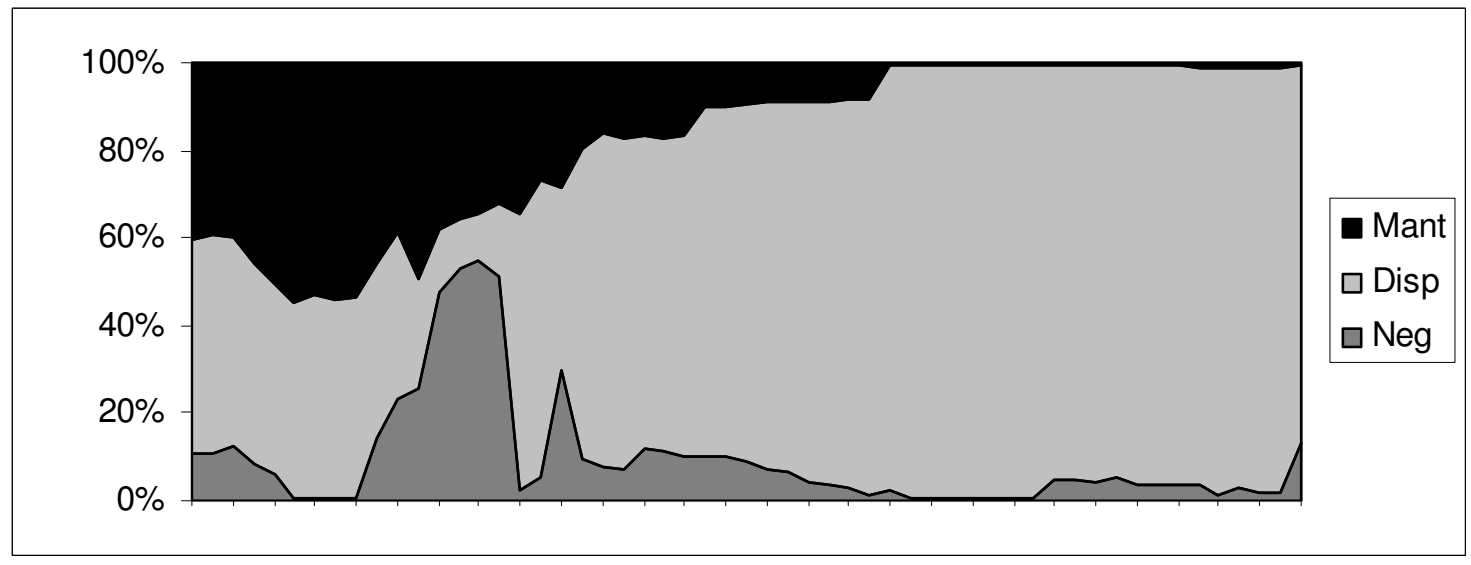


Figura 4.12 - Composição da carteira do banco $M$

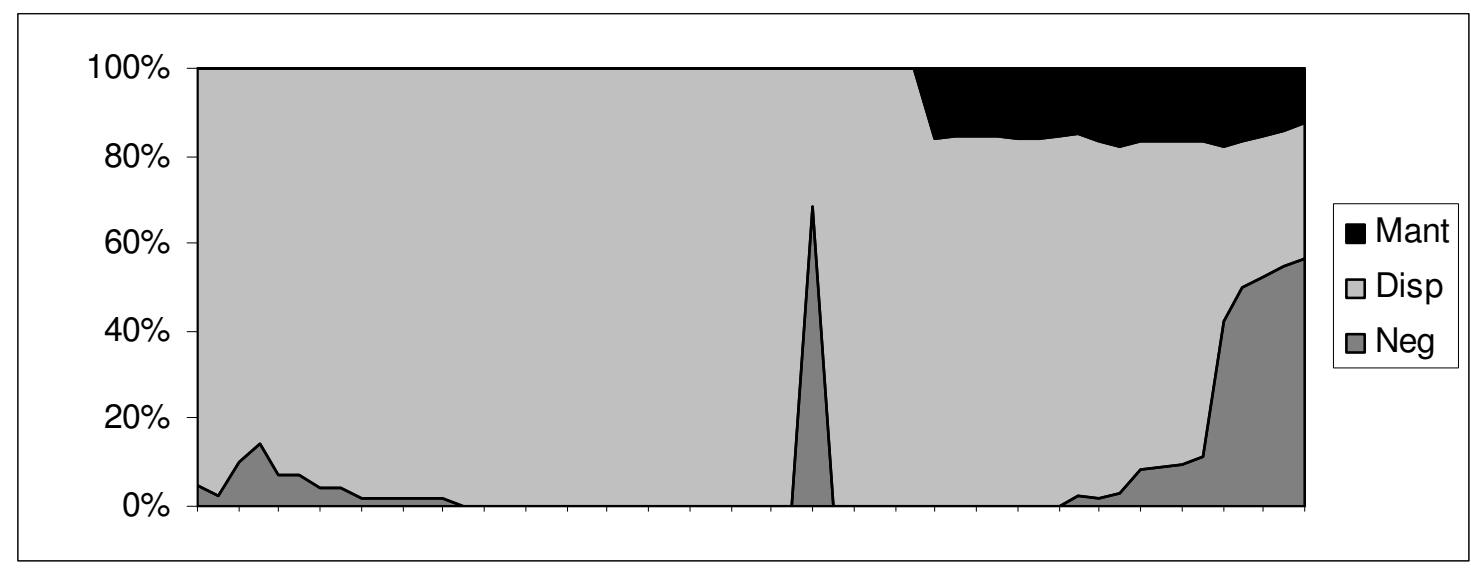

Figura 4.13 - Composição da carteira do banco $N$

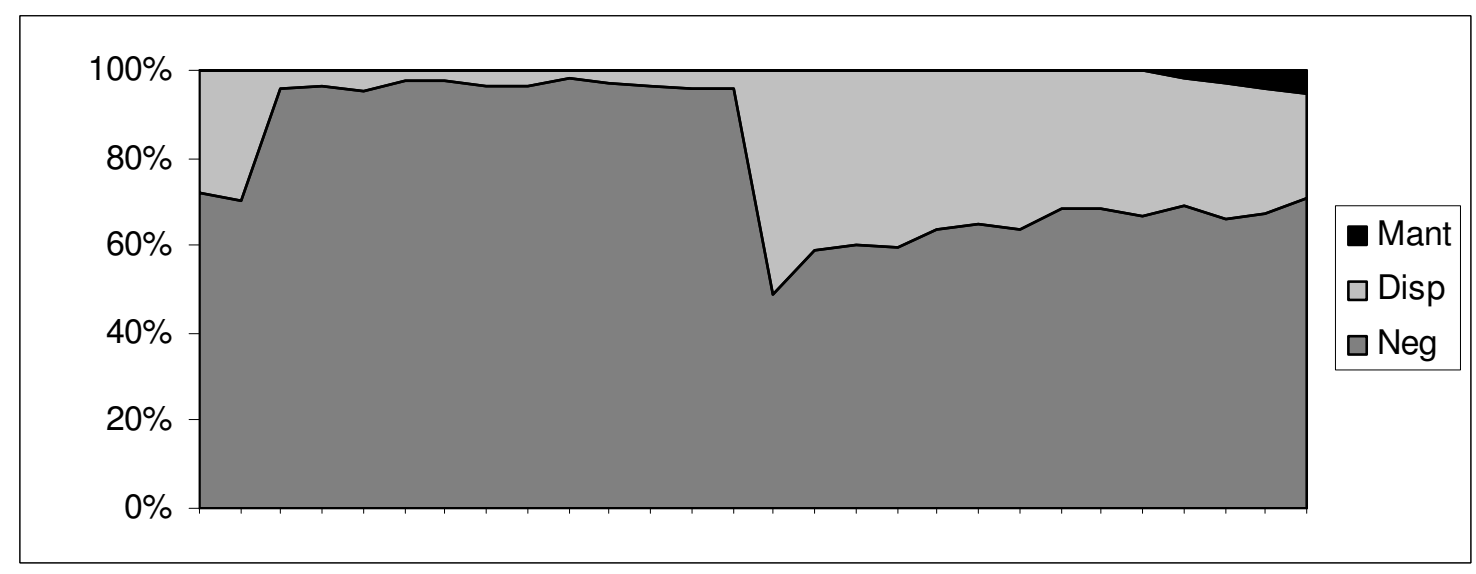

Figura 4.14 - Composição da carteira do banco $Q$

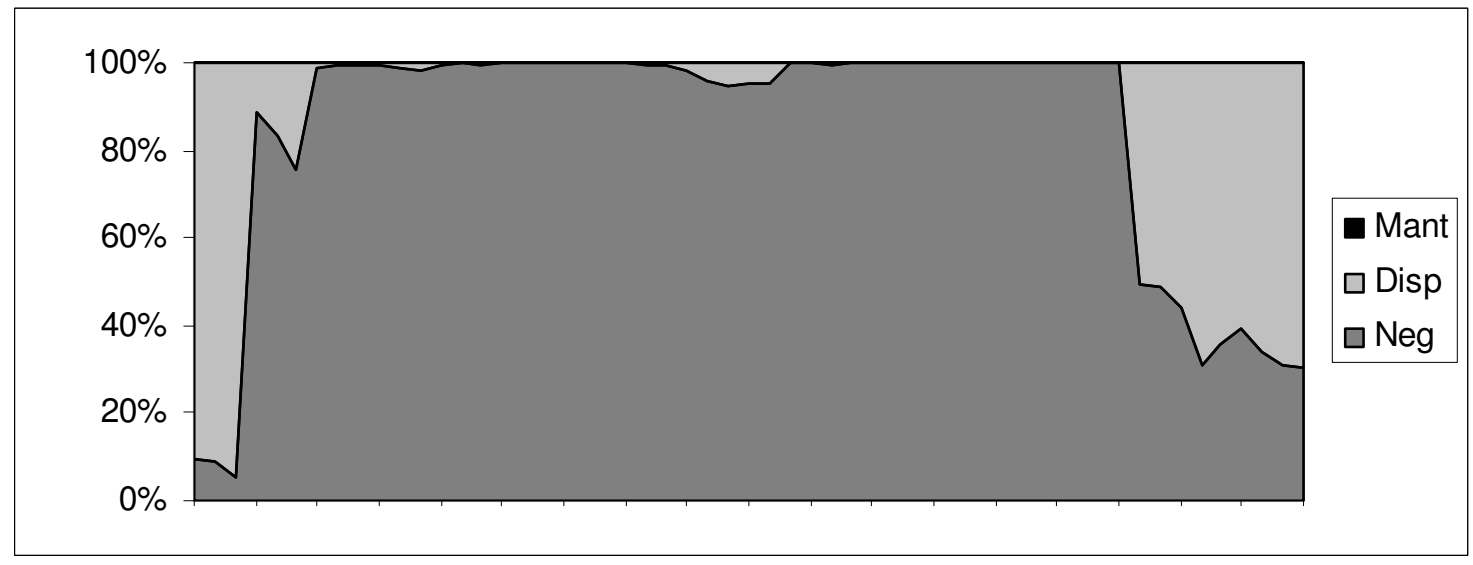


"Art. 50 - A reavaliação quanto à classificação dos títulos e valores mobiliários, de acordo com os critérios previstos no art. 1ํ, somente poderá ser efetuada por ocasião da elaboração dos balanços semestrais [grifo nosso]" (Circular no 3068).

Desta forma, pode-se afirmar que estes bancos comerciais praticaram gerenciamento de resultados por meio das operações com títulos e valores mobiliários. O que é confirmado pelas fortes correlações observadas entre os percentuais de cada categoria (Tabela 4.5).

Tabela 4.5 - Correlação entre os percentuais de TVM em carteira (2)

\begin{tabular}{cccc}
\hline IF & $\begin{array}{c}\text { Correlação } \\
\text { Neg x Disp }\end{array}$ & $\begin{array}{c}\text { Correlação } \\
\text { Disp x Mant }\end{array}$ & $\begin{array}{c}\text { Correlação } \\
\text { Mant x Neg }\end{array}$ \\
\hline $\mathrm{E}$ & $-0,9707$ & $-0,4398$ & 0,2112 \\
\hline $\mathrm{I}$ & $-0,7638$ & $-0,8892$ & 0,3838 \\
\hline $\mathrm{M}$ & $-0,9359$ & $-0,6354$ & 0,3227 \\
\hline $\mathrm{N}$ & $-0,9968$ & 0,1531 & $-0,2314$ \\
\hline
\end{tabular}

Note que a Tabela 4.5, que mostra os coeficientes de correlação entre as categorias de títulos, não apresenta os dados relativos ao banco $Q$, pois este nunca classificou títulos como mantidos até o vencimento. $O$ coeficiente entre as demais categoria, forçosamente, é -1.

Finalmente, existe um grupo de bancos comerciais que apresentaram alta variabilidade nos percentuais de cada categoria da carteira de títulos e valores mobiliários. As composições das carteiras dos bancos $\mathrm{G}, \mathrm{H}, \mathrm{J}, \mathrm{K}, \mathrm{O}$ e P são apresentadas nas Figuras 4.15, 4.16, 4.17, 4.18, 4.19 e 4.20, respectivamente. 
Figura 4.15 - Composição da carteira do banco $G$

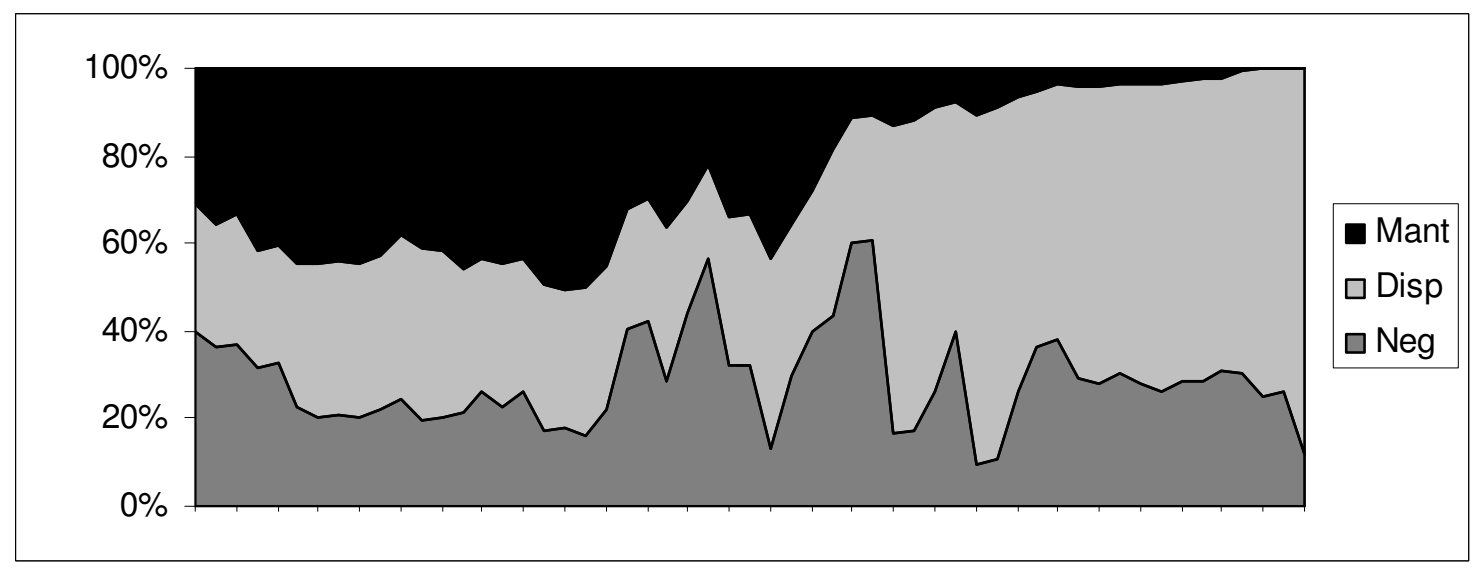

Figura 4.16 - Composição da carteira do banco $H$

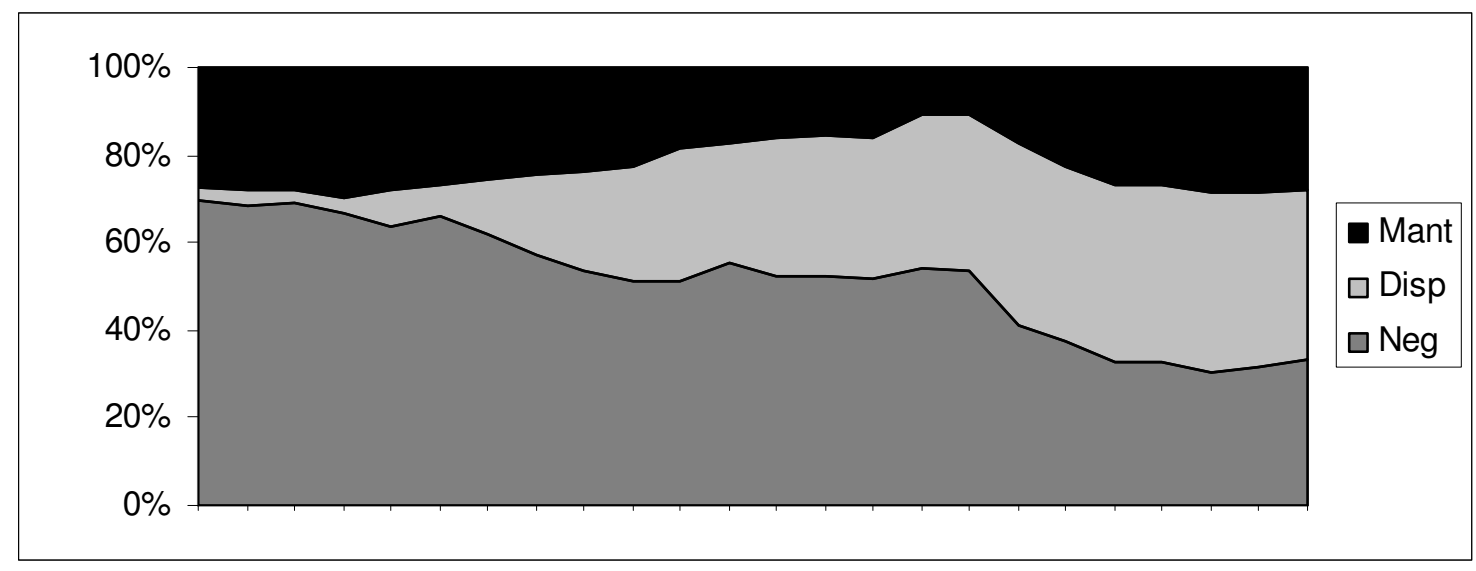

Figura 4.17 - Composição da carteira do banco J

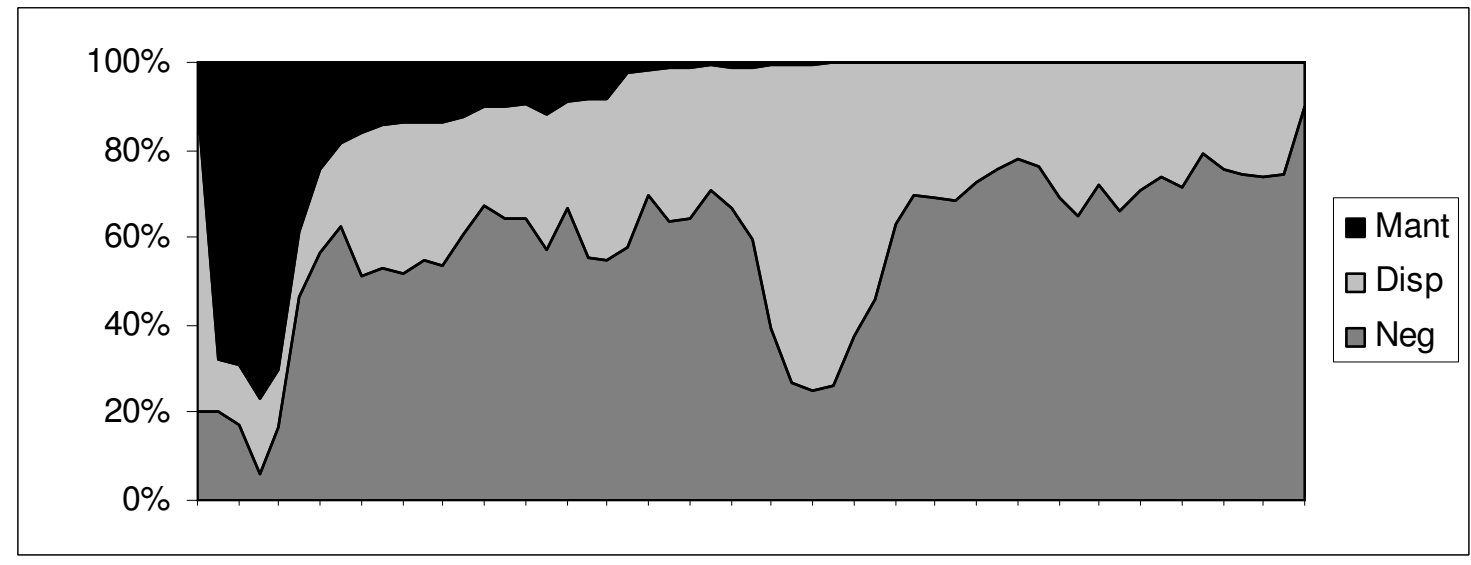


Figura 4.18 - Composição da carteira do banco K

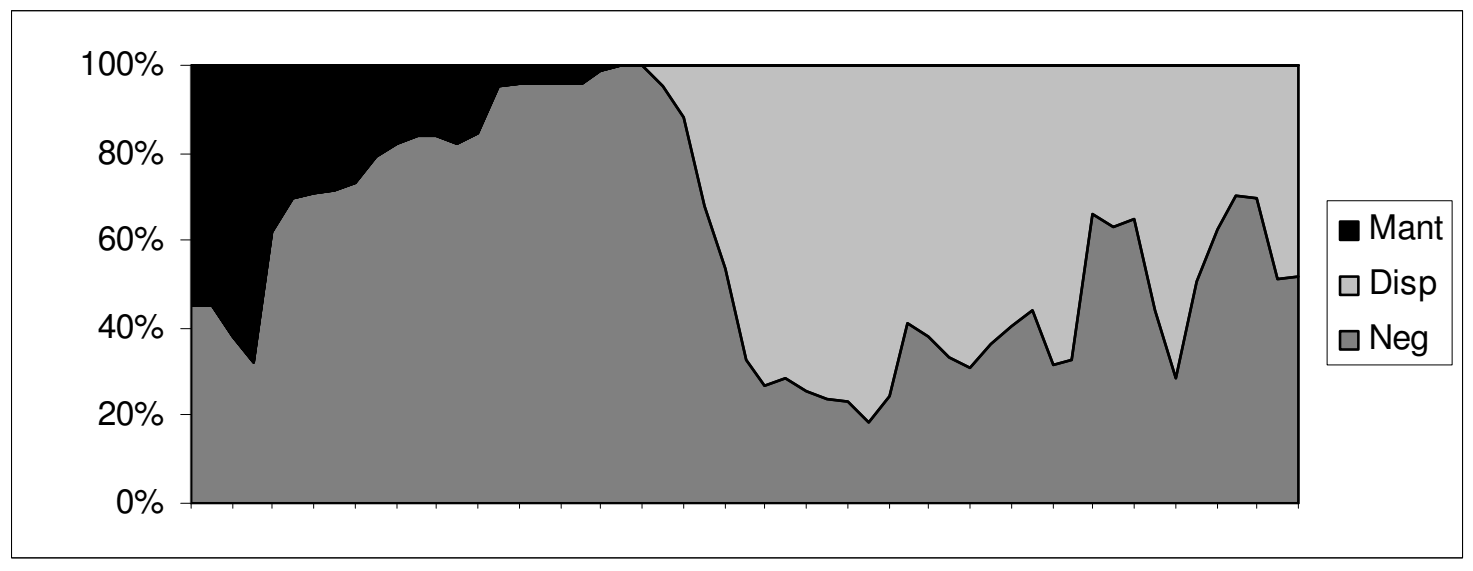

Figura 4.19 - Composição da carteira do banco $O$

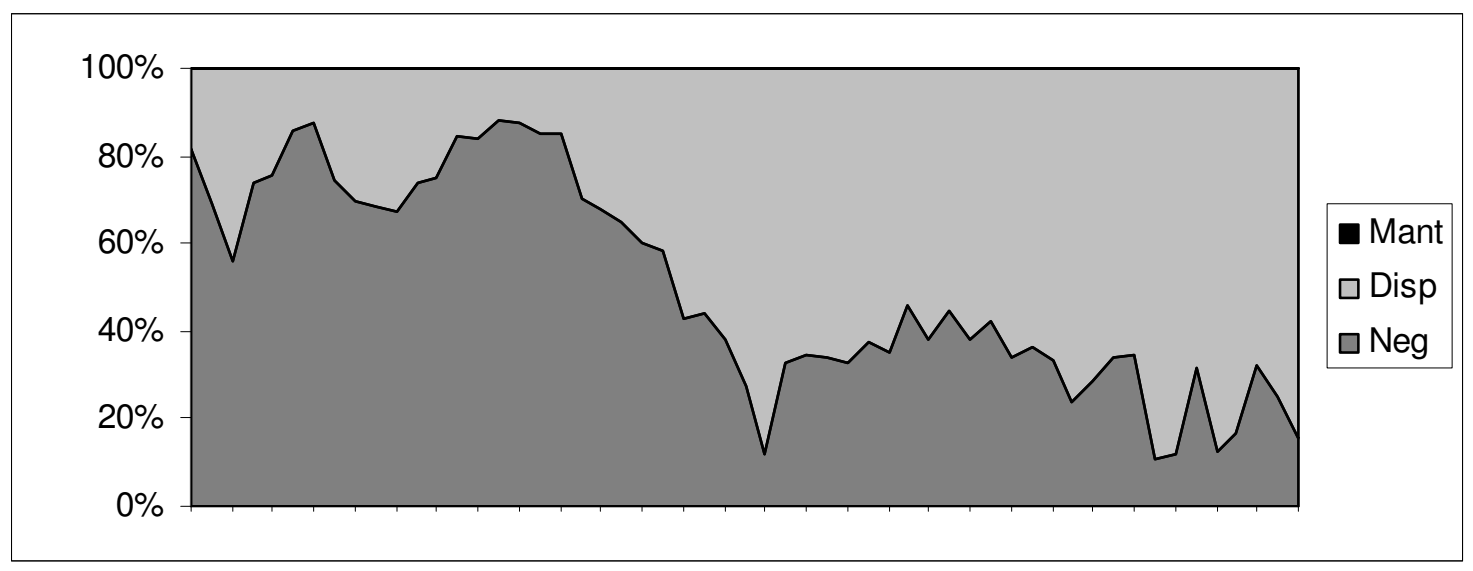

Figura 4.20 - Composição da carteira do banco $P$

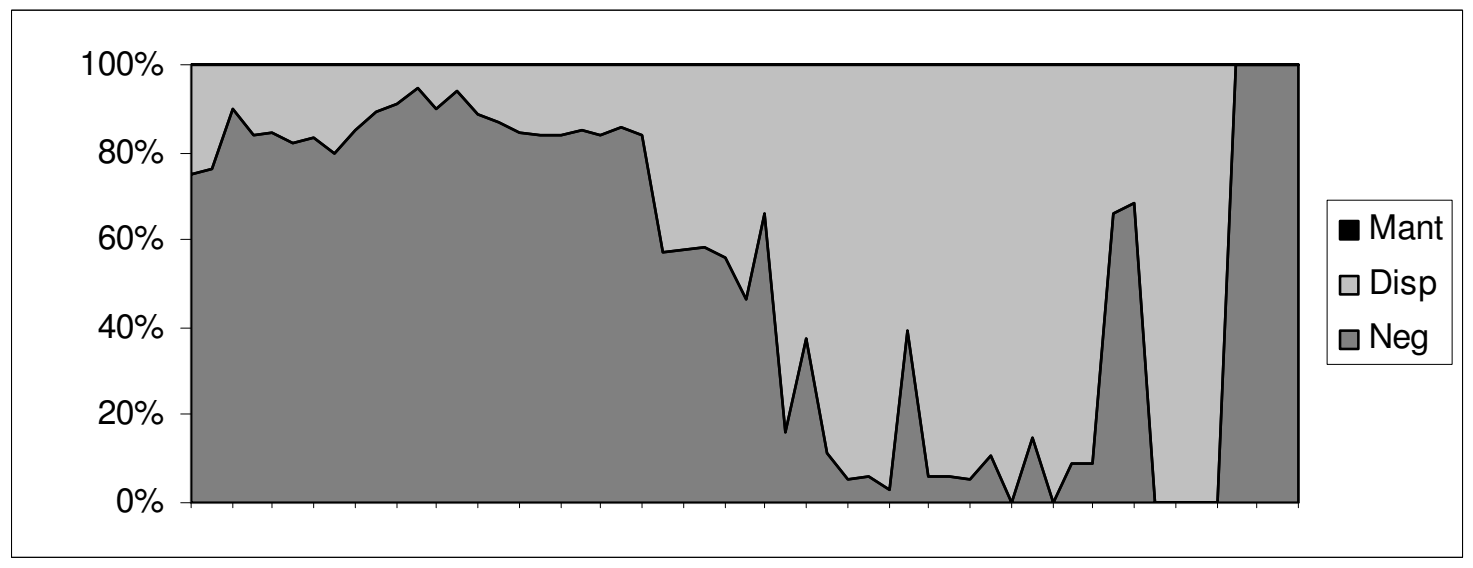


Devido às freqüentes variações nos percentuais mantidos em carteira dos títulos para negociação e títulos disponíveis para a venda, a prática do gerenciamento de resultados por parte destes bancos é, até certo ponto, esperada.

Algumas observações merecem ser feitas para dirimir dúvidas que podem surgir em sentido contrário. $\mathrm{O}$ banco $\mathrm{H}$ (Figura 4.16) apresenta variações mais suaves que os demais, pois este é um daqueles dois casos citados no ínicio, em que o banco apresentou informações para um número menor de períodos.

Os bancos G e J (Figuras 4.15 e 4.17), apesar de apresentarem coeficientes de correlação moderados (Tabela 4.6) entre os títulos para negociação e os títulos disponíveis para a venda, as variações mais significativas ocorreram após a publicação dos balanços semestrais, ocasião em que pode haver a reclassificação dos títulos, conforme a Circular nํ 3068 do Banco Central do Brasil.

Tabela 4.6 - Correlação entre os percentuais de TVM em carteira (3)

\begin{tabular}{cccc}
\hline IF & $\begin{array}{c}\text { Correlação } \\
\text { Neg x Disp }\end{array}$ & $\begin{array}{c}\text { Correlação } \\
\text { Disp x Mant }\end{array}$ & $\begin{array}{c}\text { Correlação } \\
\text { Mant x Neg }\end{array}$ \\
\hline$G$ & $-0,3996$ & $-0,8154$ & $-0,2049$ \\
\hline$H$ & $-0,9095$ & $-0,4214$ & 0,0064 \\
\hline$J$ & $-0,3968$ & $-0,4058$ & $-0,6779$ \\
\hline $\mathrm{K}$ & $-0,8285$ & $-0,5670$ & 0,0084 \\
\hline
\end{tabular}

Os coeficientes de Pearson não foram calculados para os bancos $\mathrm{O}$ e $\mathrm{P}$, pois estes nunca registraram títulos na categoria mantidos até o vencimento. 
A importância da categoria dos títulos mantidos até o vencimento (Tabela 4.2) não foi considerada razoável como parâmetro de agrupamento dos bancos comerciais para efeito de análise. Contudo, pode ser considerada um bom direcionador para os indícios de gerenciamento de resultados relativos a operações com títulos e valores mobiliários, como demonstrado na Tabela 4.7.

Tabela 4.7 - Bancos com indícios de gerenciamento de resultados

\begin{tabular}{ccc}
\hline $\begin{array}{c}\text { Bancos } \\
\text { comerciais }\end{array}$ & $\begin{array}{c}\text { Percentual dos } \\
\text { títulos mantidos } \\
\text { até o vencimento }\end{array}$ & $\begin{array}{c}\text { Indícios de } \\
\text { gerenciamento } \\
\text { de resultados }\end{array}$ \\
\hline $\mathrm{A}, \mathrm{B}, \mathrm{C} \mathrm{e} \mathrm{D}$ & entre $56 \%$ e $63 \%$ & - \\
\hline $\mathrm{E} \mathrm{e} \mathrm{F}$ & entre $36 \%$ e $37 \%$ & $\mathrm{E}$ \\
\hline $\mathrm{G}, \mathrm{He} \mathrm{l}$ & entre $18 \%$ e $25 \%$ & $\mathrm{G}, \mathrm{H}$ e I \\
\hline $\mathrm{J}, \mathrm{K}, \mathrm{L}$ e M & entre $5 \%$ e $10 \%$ & $\mathrm{~J}, \mathrm{Ke} \mathrm{M}$ \\
\hline $\mathrm{N}, \mathrm{O}, \mathrm{P}$ e Q & menos de $1 \%$ & $\mathrm{~N}, \mathrm{O}, \mathrm{P} \mathrm{e} \mathrm{Q}$ \\
\hline
\end{tabular}

É importante ressaltar que o objetivo deste trabalho era simplesmente detectar a presença de indícios da utilização das operações com títulos e valores mobiliários para gerenciar os resultados. Assim, este trabalho não levou em consideração a freqüência e a intensidade com que este gerenciamento é praticado, o que poderia ser estudado em futuros estudos.

Da inspeção visual das carteiras dos dezessete bancos comerciais analisados, nota-se que o percentual dos títulos mantidos até o vencimento somente foi aumentado sistematicamente pelo banco $A$. Os bancos $M$ e $N$ passaram a utilizar esta categoria nos últimos meses. Observe abaixo as Figuras 4.21 e 4.22, que mostram a evolução dos percentuais médios de cada categoria de título ao longo do tempo. 
Figura 4.21 - Carteira de títulos mantidos até o vencimento

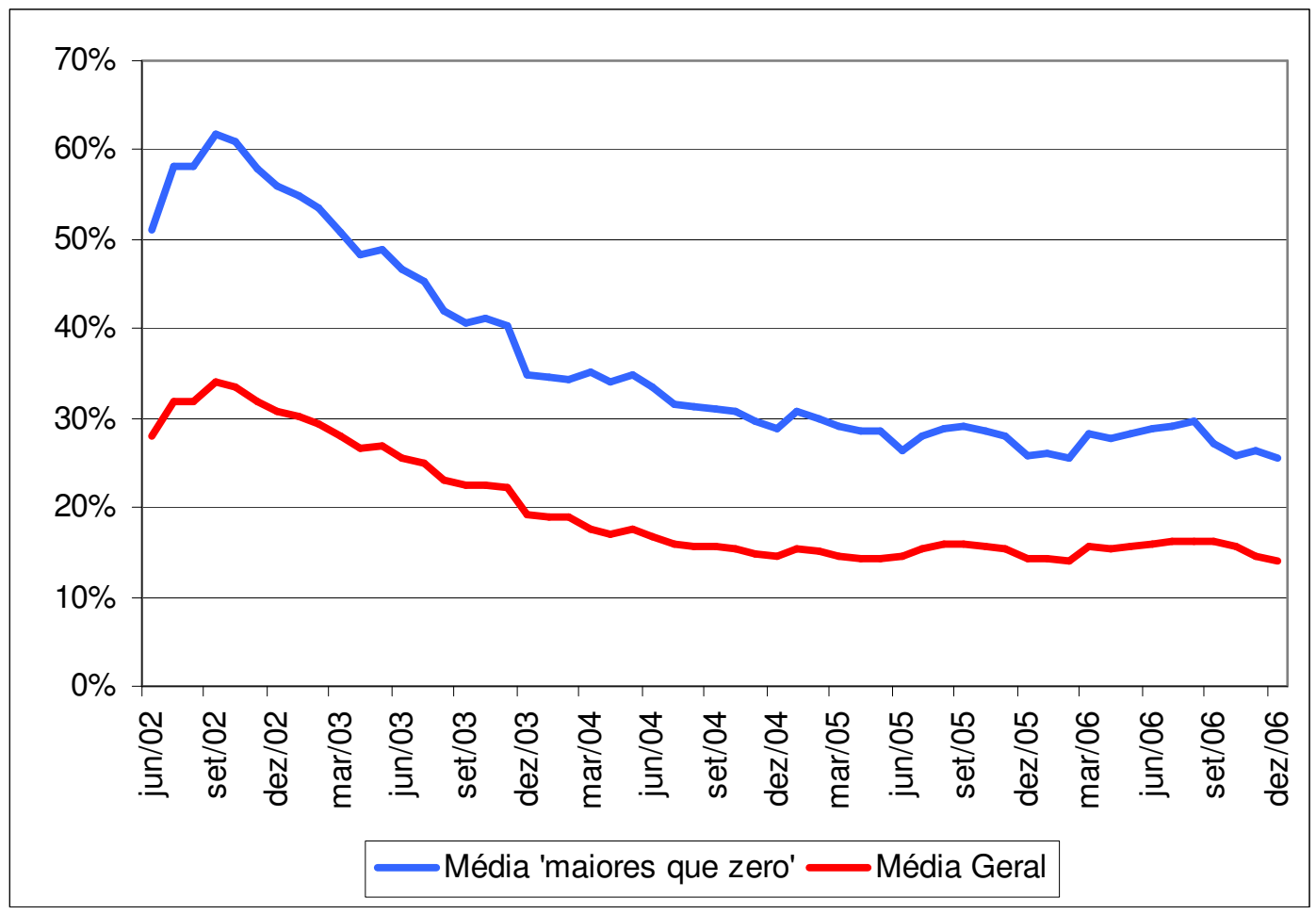

Figura 4.22 - Carteira de títulos para negociação e disponíveis para a venda

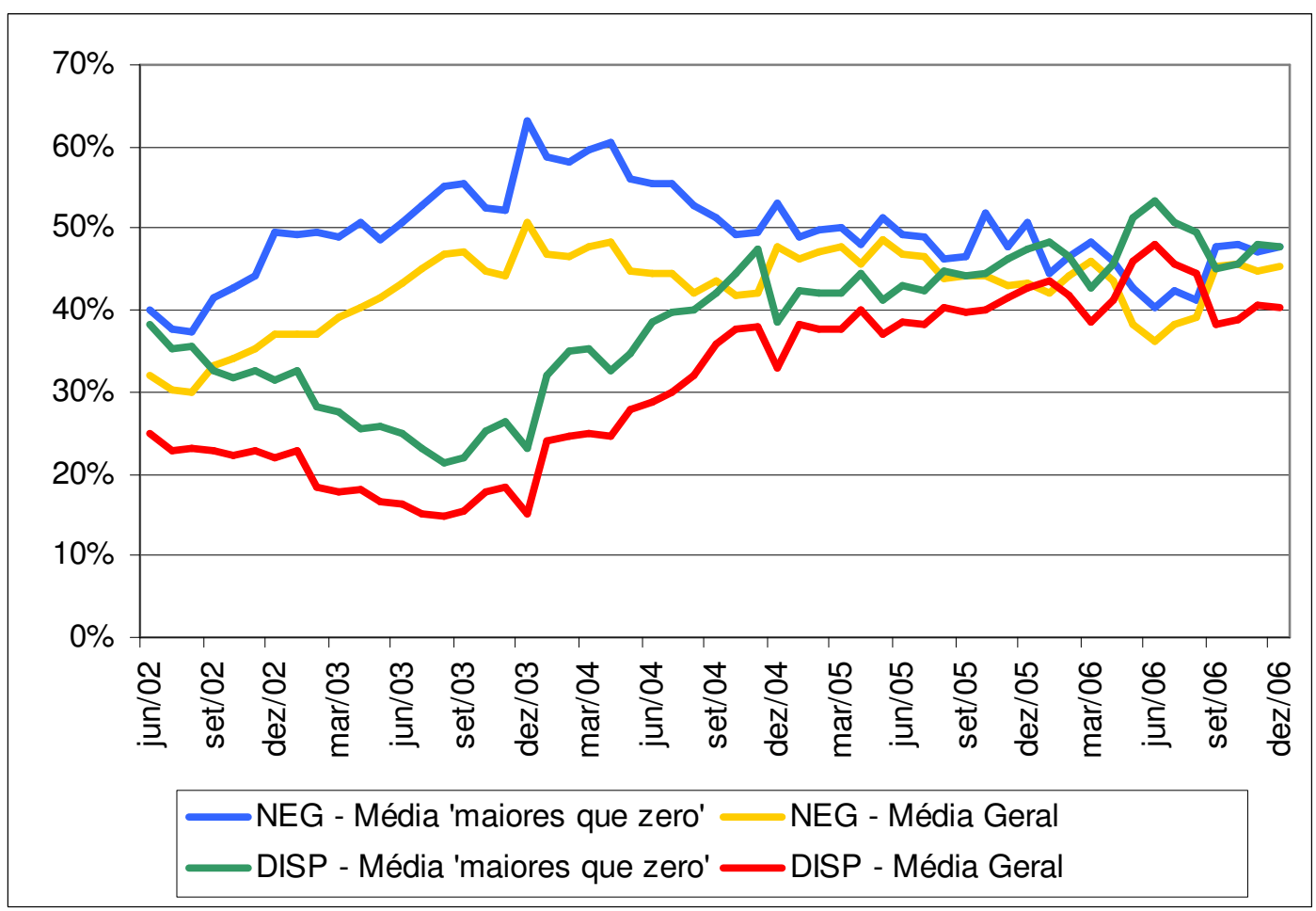


A média ${ }^{54}$ dos percentuais mantidos em carteira pelos bancos comerciais dos títulos mantidos até o vencimento apresenta diminuição sistemática nos primeiros anos, até atingir uma certa estabilidade nos últimos períodos. Apenas os bancos $\mathrm{A}, \mathrm{C}, \mathrm{D}, \mathrm{E}$ e H apresentaram percentuais significativos dos títulos mantidos até o vencimento, enquanto vários bancos praticamente não os têm em carteira. Isto explica a grande diferença observada entre as médias calculadas nesta categoria, o que não foi observado nas demais categorias. Estudos poderiam ser feitos sobre a política de classificação dos títulos e valores mobiliários pelas instituições financeiras.

\subsection{Operações de Crédito}

"Art. 6 - A provisão para fazer face aos créditos de liquidação duvidosa deve ser constituída mensalmente, não podendo ser inferior ao somatório [grifo nosso] decorrente da aplicação dos percentuais a seguir mencionados (...)" (Resolução $n^{0}$ 2682).

A Resolução no 2682 do CMN estabelece apenas o valor mínimo para a provisão relativa aos créditos de liquidação duvidosa, os bancos comerciais, em tese, poderiam gerenciar resultados alterando o valor da provisão que excedesse a este mínimo exigido (doravante denominada "provisão excedente"), conforme seus interesses em obter mais ou menos resultado no período.

\footnotetext{
${ }^{54}$ A "média 'maiores que zero"' foi calculada apenas em relação aos bancos comerciais que possuíam em sua carteira títulos registrados na categoria em questão, em cada um dos 55 meses analisados. Na "média geral", todos os bancos foram considerados, mesmo aqueles que não utilizaram tal categoria naquele período.
} 
FUJI (2004) realizou teste específico para verificar se, com a nova regulamentação sobre a constituição de provisão para fazer face aos créditos de liquidação duvidosa - Resolução ํo 2682 em substituição à Resolução no 1748 -, as instituições financeiras brasileiras alteraram seu nível de provisionamento.

"No estudo, buscamos averiguar a relação entre provisão para créditos de liquidação duvidosa e operações de crédito, antes e depois da Resolução 2.682/99. O Teste de Wilcoxom mostra que, com o advento da Resolução 2.682/99, 67 (sessenta e sete) bancos apresentaram aumento no nível de provisão para créditos de liquidação duvidosa, correspondendo a 91,78\% do total. Para o nível de significância de 1\%, rejeita-se a hipótese nula $\left[H_{0}\right.$ : não houve alteração significativa na relação entre operações de crédito e provisão para créditos de liquidação duvidosa] e depreende-se que houve alteração significativa na relação operações de crédito e provisão" (FUJl, 2004:85).

FUJI (2004) também realizou teste para verificar se as despesas com provisão para créditos de liquidação duvidosa possuíam ou não relação os resultados das instituições financeiras. Para tanto, realizou teste baseado no modelo proposto por MARTINEZ (2001:94).

“DespDevDuv $=\alpha_{0}+\alpha_{1}$ Res $+\alpha_{2} P+\alpha_{3}$ Op. Cred $+\varepsilon "(\text { FUJI, 2004:87) })^{55}$.

FUJI (2004:89) concluiu que "os resultados, de modo geral, confirmam a hipótese da pesquisa, ou seja, há evidências de que os maiores bancos

55 "DespDevDuv: despesas com provisão para créditos de liquidação duvidosa.

Res: Resultado, excluindo as despesas com provisão para créditos de liquidação duvidosa.

P: Passivo Exigível.

Op. Cred: operações de crédito" (FUJI, 2004:87). 
atuantes no Brasil gerenciam os resultados contábeis através da conta despesa com provisão para créditos de liquidação duvidosa, 'controlando' a variabilidade de lucros de forma a apresentar um cenário estável (income smoothing)".

Como ressaltado no item 2.2, FUJI (2004) utilizou dados disponíveis ao público, enquanto este trabalho utilizará dados disponíveis ao órgão regulador. Uma vez que os dados disponíveis para a realização deste trabalho são bastante mais analíticos, os testes serão concentrados no período de vigência da nova regulamentação, isto é, a partir de março de 2000.

Assim, o primeiro passo para realizar os testes relativos às operações de crédito é calcular a provisão exigida pela regulamentação - Resolução nํㅜㄴ 2682 -, para que se possa calcular a provisão excedente constituída pelo banco comercial, ou seja, quanto o banco provisiona além do mínimo exigido. Também será calculado o total das operações de crédito e o percentual da provisão excedente em relação ao total das operações de crédito.

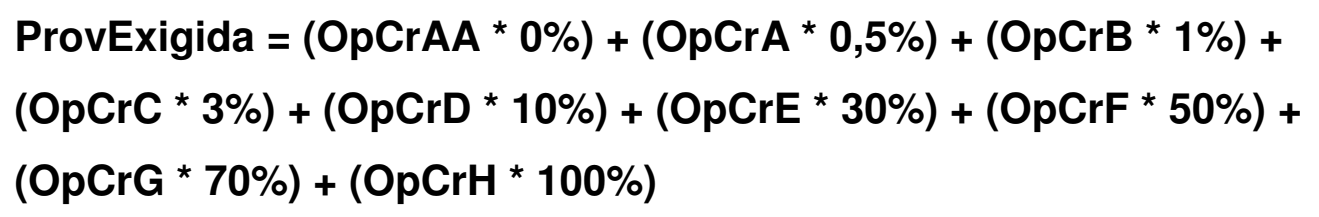

\section{PercProvExc $=$ ProvExcedente $/$ TotalOpCred}

em que:

ProvExigida $=$ provisão de crédito exigida pela legislação vigente

OpCrAA = operações de crédito classificadas, pelo banco comercial, no Nível AA para risco de crédito (3.1.1.10.00-0) 
OpCrA = operações de crédito classificadas, pelo banco comercial, no Nível A para risco de crédito (3.1.2.10.00-3)

OpCrB = operações de crédito classificadas, pelo banco comercial, no Nível B para risco de crédito (3.1.3.10.00-6)

OpCrC = operações de crédito classificadas, pelo banco comercial, no Nível C para risco de crédito (3.1.4.10.00-9)

OpCrD = operações de crédito classificadas, pelo banco comercial, no Nível D para risco de crédito (3.1.5.10.00-2)

OpCrE = operações de crédito classificadas, pelo banco comercial, no Nível E para risco de crédito (3.1.6.10.00-5)

OpCrF = operações de crédito classificadas, pelo banco comercial, no Nível F para risco de crédito (3.1.7.10.00-8)

OpCrG = operações de crédito classificadas, pelo banco comercial, no Nível G para risco de crédito (3.1.8.10.00-1)

$\mathrm{OpCrH}=$ operações de crédito classificadas, pelo banco comercial, no Nível $\mathrm{H}$ para risco de crédito (3.1.9.10.00-4)

ProvExcedente = provisão de crédito, constituída pelo banco comercial, acima do mínimo exigido pela legislação vigente

ProvOpCred $=$ provisão para operações de crédito (conta retificadora de ativo), constituída pelo banco comercial (1.6.9.00.00-8)

TotalOpCred $=$ total das operações de crédito concedidas pelo banco PercProvExc $=$ percentual da provisão excedente em relação ao total das operações de crédito

A provisão excedente - percentual em relação ao total das operações de crédito - praticada pelos bancos comerciais pode ser avaliada na Tabela 4.8. Cumpre ressaltar que um banco não registrou as informações referentes a operações de crédito na instituição líder do conglomerado e dois outros bancos 
comerciais não apresentaram provisão excedente ao longo do período

analisado. Logo, a tabela traz estatísticas relativas a dezessete bancos, que estão ordenados pela média da provisão excedente.

Tabela 4.8 - Estatísticas sobre provisão excedente dos bancos

\begin{tabular}{|c|c|c|c|c|c|c|c|c|}
\hline IF & Média $^{56}$ & Média $>0^{57}$ & Mínimo $^{58}$ & Mediana $^{59}$ & 3 Quartil & Máximo & $>=0^{60}$ & $<0^{61}$ \\
\hline$A$ & $-1,51 \%$ & $0,83 \%$ & $-12,55 \%$ & $0,20 \%$ & $1,11 \%$ & $4,03 \%$ & 57 & 25 \\
\hline$B$ & $-1,11 \%$ & $0,71 \%$ & $-26,71 \%$ & $0,72 \%$ & $1,00 \%$ & $1,47 \%$ & 73 & 9 \\
\hline $\mathrm{C}$ & $-1,00 \%$ & $0,00 \%$ & $-30,27 \%$ & $0,00 \%$ & $0,00 \%$ & $0,12 \%$ & 43 & 39 \\
\hline $\mathrm{D}$ & $-0,18 \%$ & $0,02 \%$ & $-4,19 \%$ & $0,00 \%$ & $0,00 \%$ & $0,30 \%$ & 63 & 19 \\
\hline$E$ & $-0,01 \%$ & $0,71 \%$ & $-3,53 \%$ & $0,00 \%$ & $0,00 \%$ & $2,07 \%$ & 19 & 63 \\
\hline$F$ & $0,01 \%$ & $0,01 \%$ & $-0,03 \%$ & $0,00 \%$ & $0,00 \%$ & $0,49 \%$ & 41 & 41 \\
\hline$G$ & $0,01 \%$ & $0,02 \%$ & $-0,02 \%$ & $0,00 \%$ & $0,00 \%$ & $0,53 \%$ & 60 & 22 \\
\hline $\mathrm{H}$ & $0,04 \%$ & $0,08 \%$ & $-0,06 \%$ & $0,00 \%$ & $0,00 \%$ & $0,47 \%$ & 44 & 38 \\
\hline 1 & $0,05 \%$ & $0,11 \%$ & $-0,01 \%$ & $0,00 \%$ & $0,00 \%$ & $0,39 \%$ & 41 & 41 \\
\hline $\mathrm{J}$ & $0,13 \%$ & $0,16 \%$ & $-0,98 \%$ & $0,00 \%$ & $0,03 \%$ & $1,17 \%$ & 72 & 10 \\
\hline $\mathrm{K}$ & $0,16 \%$ & $0,16 \%$ & $0,00 \%$ & $0,00 \%$ & $0,00 \%$ & $1,18 \%$ & 82 & 0 \\
\hline $\mathrm{L}$ & $0,34 \%$ & $0,34 \%$ & $0,01 \%$ & $0,29 \%$ & $0,41 \%$ & $1,14 \%$ & 82 & 0 \\
\hline$M$ & $0,57 \%$ & $0,57 \%$ & $0,00 \%$ & $0,00 \%$ & $1,51 \%$ & $2,21 \%$ & 82 & 0 \\
\hline $\bar{N}$ & $0,97 \%$ & $0,97 \%$ & $0,20 \%$ & $0,78 \%$ & $1,49 \%$ & $2,45 \%$ & 82 & 0 \\
\hline $\mathrm{O}$ & $1,07 \%$ & $1,07 \%$ & $0,00 \%$ & $1,08 \%$ & $1,49 \%$ & $1,93 \%$ & 82 & 0 \\
\hline$P$ & $1,35 \%$ & $1,35 \%$ & $0,12 \%$ & $1,60 \%$ & $1,92 \%$ & $2,39 \%$ & 82 & 0 \\
\hline Q & $3,10 \%$ & $3,10 \%$ & $1,54 \%$ & $2,19 \%$ & $3,69 \%$ & $9,38 \%$ & 82 & 0 \\
\hline
\end{tabular}

Dez dos dezenove bancos comerciais (de A a J) apresentaram valores negativos para a provisão excedente, o que indica que a provisão efetuada não atendia ao requerido na legislação, em determinado período. No entanto,

\footnotetext{
${ }^{56}$ Média de todos os valores relativos à provisão excedente. Caso o banco comercial tenha realizado uma provisão menor que a exigida pela legislação, haveria uma falta de provisão, indicado por valores negativos.

${ }^{57}$ Média dos valores maiores que zero, isto é, aqueles valores em que realmente há provisão excedente relativa às operações de crédito.

${ }^{58}$ Valor mínimo observado, enquanto que Máximo mostrará o valor máximo observado.

${ }^{59}$ Indica que metade das observações possui valores iguais ou inferiores à mediana e a outra metade possui valores iguais ou superiores. O $3^{\circ}$ Quartil, assim como a mediana também é uma medida de tendência central, contudo $3 / 4$ das observações são iguais ou inferiores a seu valor e $1 / 4$ das observações são iguais ou superiores a seu valor. Observe que, em casos particulares, a mediana e o $3^{\circ}$ quartil podem ser iguais a zero.

${ }^{60}$ Número de observações maiores ou iguais a zero.

${ }^{61}$ Número de observações menores que zero.
} 
apenas cinco instituições (de A a E) apresentaram valores significativos relativos à falta de provisão.

É importante salientar que no início da vigência da nova norma sobre classificação das operações de credito e regras para constituição de provisão para créditos de liquidação duvidosa - Resolução no 2682 em substituição à Resolução no 1748 - o Banco Central do Brasil não aceitava que os bancos comerciais constituíssem provisões maiores que o estabelecido pela legislação. Após muitas análises e discussões, foi adotado o entendimento que a Resolução no 2682 estabelecia o valor mínimo da provisão para créditos de liquidação duvidosa. Tal interpretação, se por um lado confere maior flexibilidade aos bancos comerciais para administrarem seu risco de crédito, por outro lado possibilita que os resultados sejam gerenciados.

A provisão excedente dividida pelo total das operações de crédito (Tabela 4.8) possui valores médios entre $-1,51 \%$ e $3,10 \%$ e medianas entre $0 \%$ e $2,19 \%$. Estes valores, aparentemente pequenos, são significativos se comparados com os valores do resultado mensal dividido pelo total das operações de crédito, como mostrado na Tabela 4.9.

Tabela 4.9 - Resultados versus total das operações de crédito

\begin{tabular}{llllllll}
\hline Média & Média >0 & Mínimo & Mediana & 30 Quartil & Máximo & $>=0$ & $<0$ \\
\hline $0,34 \%$ & $0,44 \%$ & $-2,65 \%$ & $0,41 \%$ & $0,56 \%$ & $1,37 \%$ & 75 & 7 \\
\hline
\end{tabular}

Comparando-se as médias ou as medianas, da provisão excedente e do resultado, vê-se que pequenas variações - em torno de 0,5\% - na provisão excedente são suficientes para efetivamente gerenciar resultados. 
Figura 4.23 - Provisão excedente dos bancos $A$ a $E$

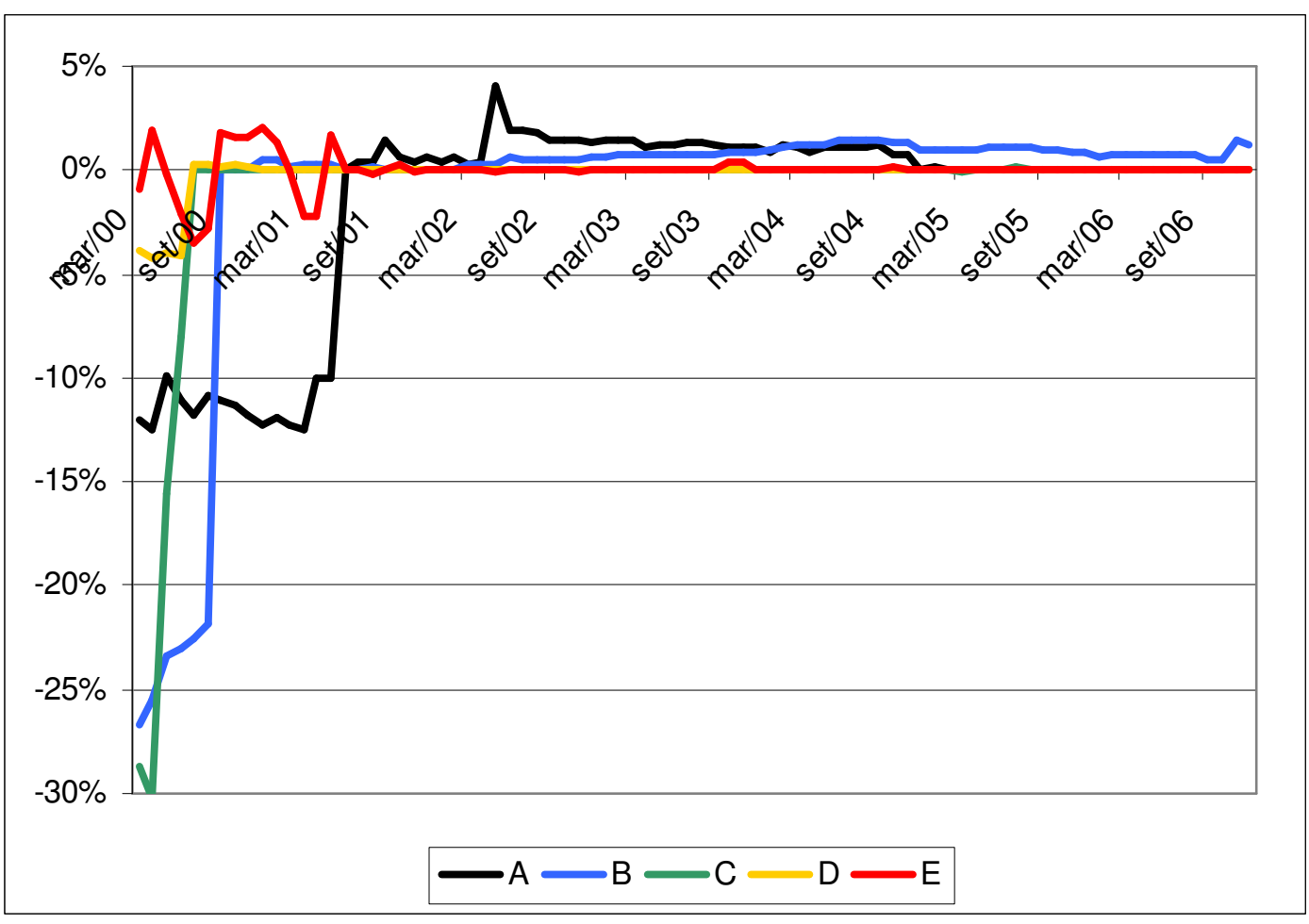

Figura 4.24 - Provisão excedente dos bancos $A$ a $E$ (2)

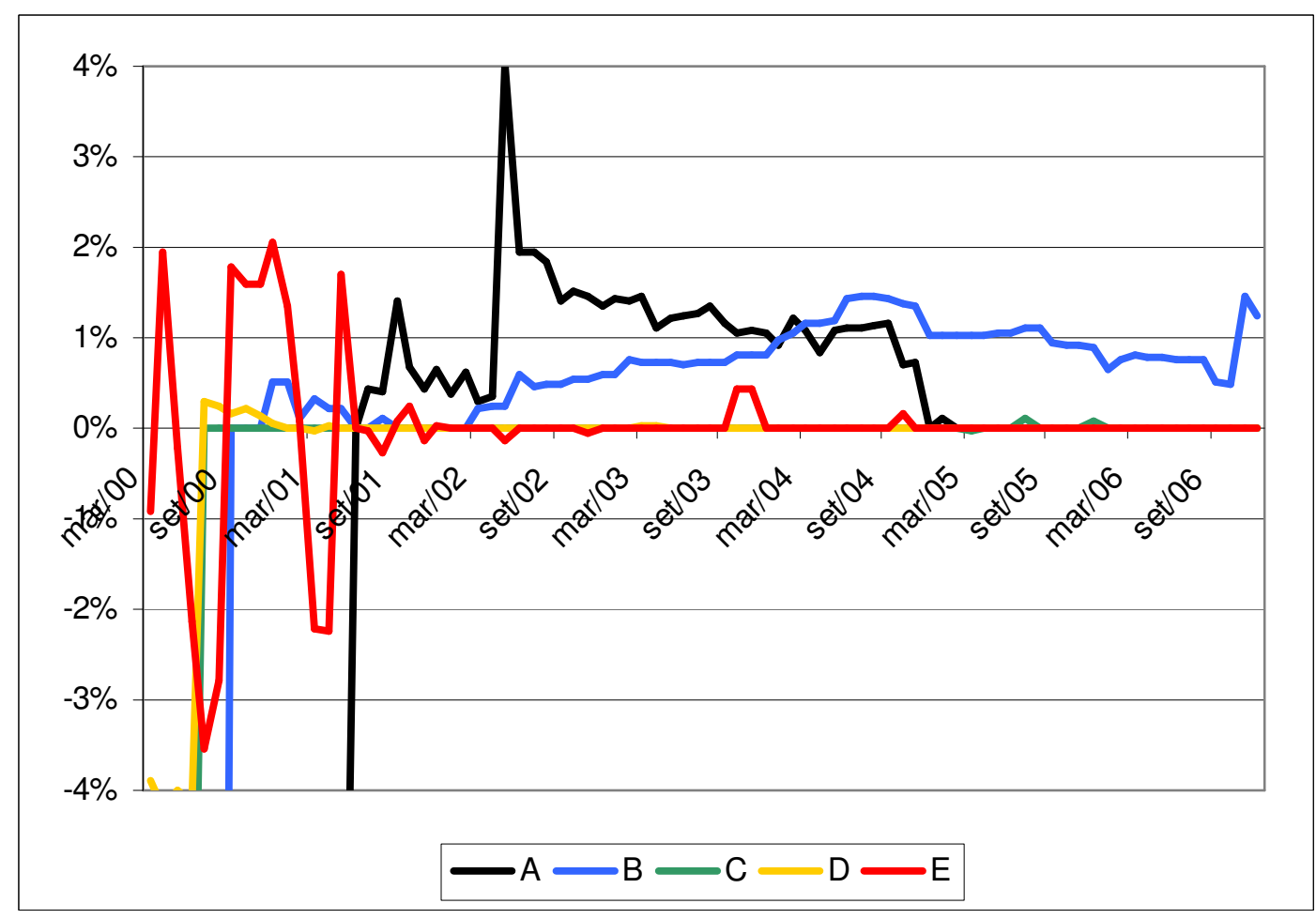


Figura 4.25 - Provisão excedente dos bancos $F$ a I

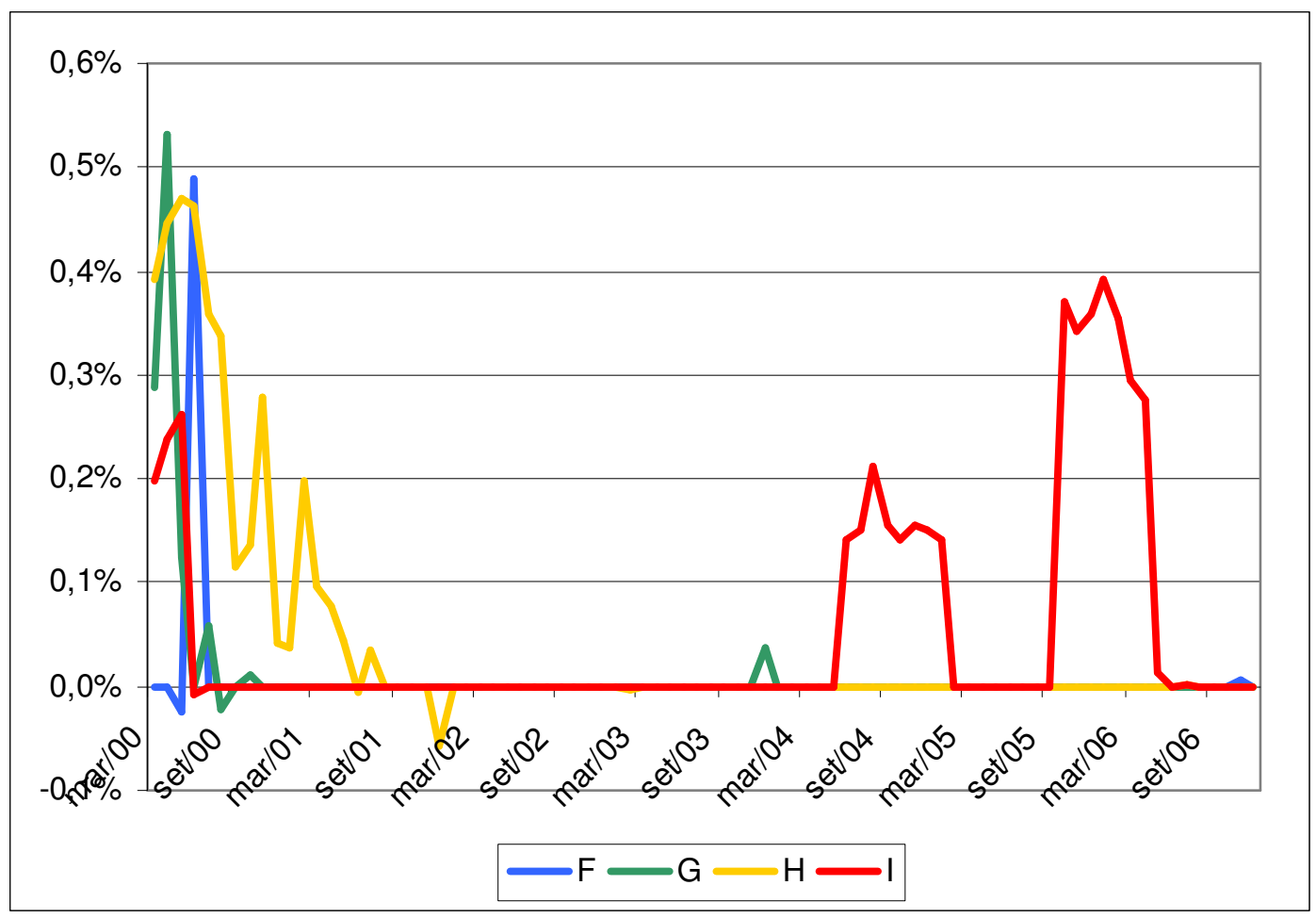

Figura 4.26 - Provisão excedente dos bancos J a M

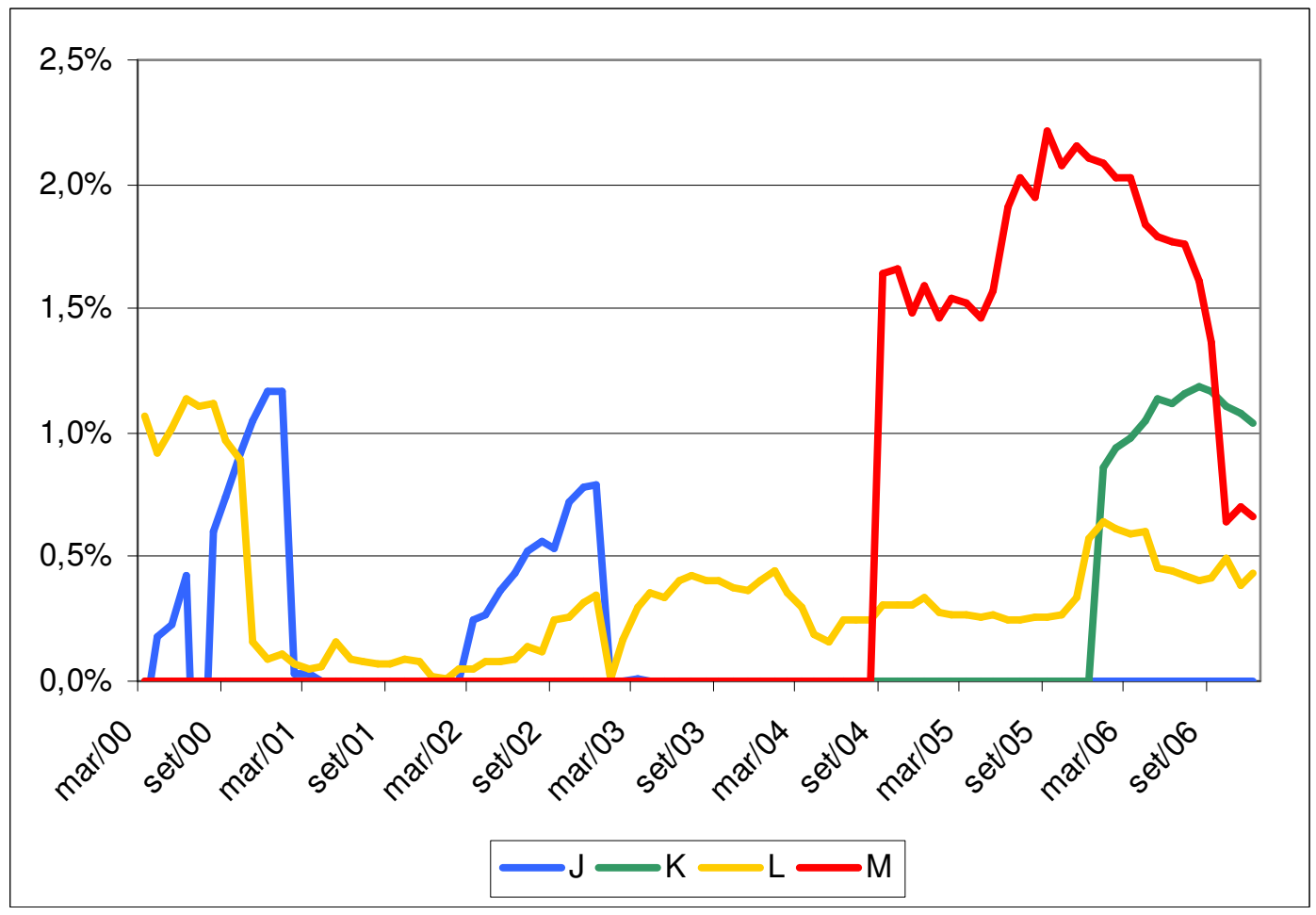


Figura 4.27 - Provisão excedente dos bancos $N$ a $Q$

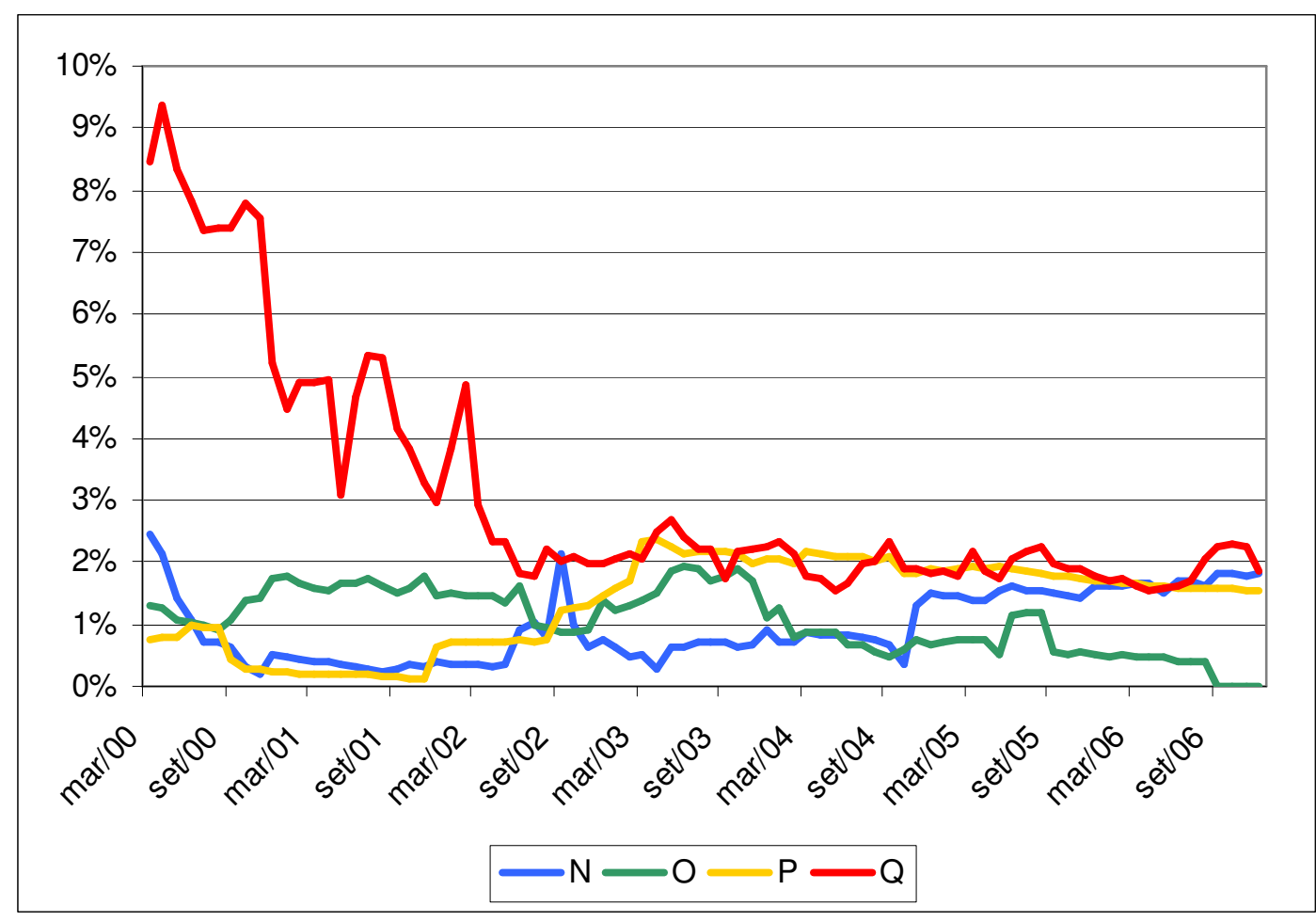

Os bancos $\mathrm{C}^{62}$, D e E apresentaram problemas de falta da provisão exigida logo após a vigência da nova norma, sendo que dois deles resolveram o problema do provisionamento por ocasião da elaboração do balanço seguinte, em junho de 2000. Resolvidos estes problemas, praticamente não apresentaram mais provisão excedente. Os bancos $F, G$ e $H$, apresentaram provisão excedente no início do período analisado. Uma vez reduzido o nível de provisionamento para o estabelecido na Resolução № 2682, também não apresentaram mais provisão excedente. Deste modo, não há indícios de que estes bancos comerciais tenham utilizado a provisão para operações de crédito para gerenciar seus resultados.

\footnotetext{
${ }^{62} \mathrm{Em}$ virtude do dever de sigilo determinado pela Lei Complementar $\mathrm{n} \times$ 105, de 10 de janeiro de 2001, a ordem e as denominações - banco A, banco B, ..., banco $T$ - apresentados em cada uma das tabelas ou figuras, não guardarão qualquer relação entre si. Em outras palavras, nada indica que o banco A de uma figura ou tabela também seja denominado como banco $\mathrm{A}$ em uma outra figura ou tabela.
} 
Para os demais onze bancos comerciais, foram calculados os coeficientes de correlações entre o total das operações de crédito e as provisões exigida e excedente (Tabela 4.10).

A correlação entre o total das operações de crédito e a provisão exigida, em teoria deve ser forte, pois quanto maior o volume de operações de crédito, maior deve ser a provisão exigida. Apenas dois bancos - B e I - apresentaram coeficientes menores que 0,7. Estes bancos apresentaram variações significativas na composição de suas carteiras, o que explicaria as baixas correlações verificadas. Em um deles, as variações estavam concentradas nas faixas de risco de crédito $A A$ e $A$; no outro, nas faixas $A, B$ e $H$.

Tabela 4.10 - Correlação entre provisões e operações de crédito

\begin{tabular}{cccc}
\hline IF & $\begin{array}{c}\text { Correlação } \\
\text { Total x Exig }\end{array}$ & $\begin{array}{c}\text { Correlação } \\
\text { Exig x Exced }\end{array}$ & $\begin{array}{c}\text { Correlação } \\
\text { Exced x Total }\end{array}$ \\
\hline $\mathrm{A}$ & 0,9065 & $-0,9908$ & $-0,8619$ \\
\hline $\mathrm{B}$ & 0,5248 & $-0,4782$ & 0,4654 \\
\hline $\mathrm{I}$ & 0,2277 & $-0,3305$ & $-0,2262$ \\
\hline $\mathrm{J}$ & 0,7579 & 0,2553 & 0,3428 \\
\hline $\mathrm{K}$ & 0,9991 & 0,7371 & 0,7224 \\
\hline $\mathrm{L}$ & 0,7308 & 0,1990 & 0,1200 \\
\hline $\mathrm{M}$ & 0,9948 & 0,9120 & 0,9420 \\
\hline $\mathrm{N}$ & 0,7862 & 0,6129 & 0,8831 \\
\hline $\mathrm{O}$ & 0,9731 & $-0,0962$ & $-0,0705$ \\
\hline $\mathrm{P}$ & 0,9568 & 0,8387 & 0,8633 \\
\hline $\mathrm{Q}$ & 0,8583 & $-0,6784$ & $-0,5613$ \\
\hline
\end{tabular}

A provisão realizada pelo banco comercial é composta da provisão exigida mais a provisão excedente. Seria esperado, dos bancos que não gerenciam resultados, que houvesse uma forte correlação entre as provisões exigida e excedente. Entretanto, apenas três dos nove bancos, que haviam apresentado forte correlação entre o total das operações de crédito e a 
provisão exigida, apresentaram forte correlações entre as provisões exigida e excedente.

Também seria esperado que houvesse uma forte correlação entre a provisão excedente e o total das operações de crédito. Neste caso, somente quatro daqueles nove bancos apresentaram coeficientes de correlação superiores a 0,7 .

Com relação ao gerenciamento de resultados, utilizando-se a provisão para operações de crédito, existem indícios suficientes para se afirmar que: (i) seis $(30 \%)$ bancos comerciais gerenciaram seus resultados; (ii) para cinco (25\%) bancos as análises não são conclusivas; e (iii) seis (30\%) não praticaram gerenciamento de resultados. Vale lembrar que três bancos não foram analisados, pois, ou não possuíam operações de crédito, ou não possuíam provisão excedente no período em questão.

\subsection{PASSivos ConTINGENTES}

Uma contingência passiva é (i) uma obrigação que somente será confirmada no futuro e que não está totalmente sob o controle da empresa ou (ii) uma obrigação advinda de eventos passados que somente agora são reconhecidos porque era improvável que a empresa tivesse que honrá-los ou o valor da obrigação não podia ser mensurado com suficiente segurança.

No âmbito dos bancos comerciais as contingências são usualmente classificadas, dependendo do fato que as originou, em contingências fiscais, trabalhistas, cíveis e administrativas. 
O plano de contas das instituições financeiras (COSIF), no entanto, possui apenas as aberturas para contingências fiscais, trabalhistas e outros. No passivo estão contabilizadas as provisões $^{63}$, enquanto no ativo estão registrados os depósitos judiciais que os bancos comerciais devem fazer para entrarem com recursos nos tribunais ${ }^{64}$.

Tabela 4.11 - Correlação entre provisões e depósitos judiciais

\begin{tabular}{cccc}
\hline IF $^{65}$ & Fiscais & Trabalhistas & Outros \\
\hline $\mathrm{A}$ & $-0,0725$ & 0,5711 & $-0,5379$ \\
\hline $\mathrm{B}$ & $-0,0461$ & 0,8470 & $\mathrm{n} / \mathrm{a}^{66}$ \\
\hline $\mathrm{C}$ & 0,0220 & 0,9405 & 0,9151 \\
\hline $\mathrm{D}$ & 0,2051 & 0,5310 & 0,0341 \\
\hline $\mathrm{E}$ & 0,3736 & 0,9723 & 0,3388 \\
\hline $\mathrm{F}$ & 0,3923 & $\mathrm{n} / \mathrm{a}$ & $\mathrm{n} / \mathrm{a}$ \\
\hline $\mathrm{G}$ & 0,4640 & $-0,2026$ & 0,8633 \\
\hline $\mathrm{H}$ & 0,4673 & 0,9799 & 0,5498 \\
\hline $\mathrm{I}$ & 0,4752 & 0,7522 & 0,1109 \\
\hline $\mathrm{J}$ & 0,4918 & 0,8776 & 0,5680 \\
\hline $\mathrm{K}$ & 0,5286 & 0,8770 & 0,8137 \\
\hline $\mathrm{L}$ & 0,6213 & $-0,1033$ & $-0,1033$ \\
\hline $\mathrm{M}$ & 0,6366 & 0,3058 & 0,7814 \\
\hline $\mathrm{N}$ & 0,7888 & 0,9490 & 0,6287 \\
\hline $\mathrm{O}$ & 0,7954 & 0,8512 & 0,3159 \\
\hline $\mathrm{P}$ & 0,8029 & 0,9302 & 0,7223 \\
\hline $\mathrm{Q}$ & 0,8522 & $\mathrm{n} / \mathrm{a}$ & 0,1658 \\
\hline $\mathrm{R}$ & 0,9468 & 0,9072 & 0,9602 \\
\hline $\mathrm{S}$ & 0,9488 & 0,7965 & 0,8335 \\
\hline $\mathrm{T}$ & 0,9994 & 0,9997 & 0,9990 \\
\hline & \multicolumn{3}{c}{}
\end{tabular}

${ }^{63}$ Provisão para Riscos Fiscais (4.9.4.50.00-6), Provisão para Passivos Contingentes Passivos Trabalhistas (4.9.9.35.10-5) e Provisão para Passivos Contingentes - Outros Passivos (4.9.9.35.90-9).

${ }^{64}$ Devedores por Depósitos em Garantia Para Interposição de Recursos Fiscais (1.8.8.40.10-4), Devedores por Depósitos em Garantia - Para Interposição de Recursos Trabalhistas (1.8.8.40.20-7) e Devedores por Depósitos em Garantia - Outros (1.8.8.40.90-8).

${ }^{65} \mathrm{Em}$ virtude do dever de sigilo determinado pela Lei Complementar $\mathrm{n}^{\circ}$ 105, de 10 de janeiro de 2001, a ordem e as denominações - banco A, banco B, ..., banco $T$ - apresentados em cada uma das tabelas ou figuras, não guardarão qualquer relação entre si. Em outras palavras, nada indica que o banco $A$ de uma figura ou tabela também seja denominado como banco $A$ em uma outra figura ou tabela.

${ }^{66}$ Nos casos marcados com "n/a", ou o banco não tinha feito depósito judicial, ou não tinha nem provisão, nem depósito judicial. Em ambos os casos é impossível calcular o coeficiente de correlação de Pearson. 
A correlação entre as provisões para passivos contingentes e os depósitos judiciais pode não ser tão direta quanto a provisão para operações de crédito e o total destas operações, contudo não é razoável que a correlação seja nula ou negativa como o observado na Tabela 4.11.

Tabela 4.12 - Ocorrências por faixas de correlação

\begin{tabular}{cccc}
\hline Correlação & Fiscais & Trabalhistas & Outros \\
\hline$r<0$ & 2 & 2 & 2 \\
\hline $0 \leq r<0,4$ & 4 & 1 & 5 \\
\hline $0,4 \leq r<0,7$ & 7 & 2 & 3 \\
\hline $0,7 \leq r<1$ & 7 & 13 & 8 \\
\hline
\end{tabular}

As contingências trabalhistas, por sua natureza - não estão totalmente fora do controle da empresa e seus valores podem ser mensurados com suficiente segurança -, apresentam coeficientes de correlação mais fortes que as demais contingências.

Pode-se dizer que as contingências trabalhistas não são utilizadas para gerenciar resultados. Entretanto, as evidências obtidas não permitem afirmar que as demais contingências passivas sejam utilizadas em tal prática, tampouco se pode afirmar o contrário. Esta área mereceria estudos mais aprofundados, principalmente se consideradas informações mais analíticas sobre os tipos de contingências. 


\section{Conclusões e Considerações Finais}

Este trabalho propôs-se a responder se existem indícios suficientes para se afirmar que os bancos comerciais no Brasil praticam alguma modalidade de gerenciamento de resultados. Para tanto, foi verificado se os bancos comerciais selecionados - instituições líderes dos vinte maiores conglomerados bancários brasileiros - utilizaram (i) os investimentos em controladas e coligadas, (ii) as operações com títulos e valores mobiliários, (iii) as operações de crédito ou (iv) os passivos contingentes para gerenciar seus resultados.

No que se refere aos investimentos em controladas e coligadas, verificou-se que apenas três das vinte instituições financeiras líderes dos conglomerados analisados apresentavam registros de valores relativos a ágios em investimentos em controladas e coligadas. Destes três bancos comerciais, dois apresentaram indícios de terem utilizado as contas de amortização de ágio para a prática de gerenciamento de resultados, pois o valor da amortização mensal apresentava variações abruptas e aparentemente inexplicáveis. 0 terceiro banco, apresentou uma forma de contabilização não totalmente aderente às práticas contábeis geralmente aceitas, porém não se pode afirmar 
que tenha utilizado as contas de amortização de ágio de investimentos para gerenciar seus resultados contábeis.

Depreende-se, então, que os investimentos em controladas ou coligadas podem ser usados para gerenciar resultados, sendo que $10 \%$ dos bancos comerciais analisados efetivamente utilizaram.

Com relação aos títulos e valores mobiliários, três bancos utilizaram apenas uma categoria para registrar seus títulos ao longo do período de análise, assim foram eliminados do estudo. Dadas as muitas exigências legais para os bancos comerciais contabilizarem seus títulos como títulos mantidos até o vencimento, as alterações nos percentuais de títulos registrados nesta categoria foram consideradas, a priori, como mudanças de políticas e não como gerenciamento de resultados.

A categoria dos títulos mantidos até o vencimento foi considerada um bom direcionador para os indícios de gerenciamento de resultados relativos a operações com títulos e valores mobiliários, pois os bancos que mantiveram nesta categoria baixos percentuais da carteira mostraram-se mais propícios a gerenciar resultados.

Nesta área de análise, $55 \%$ dos bancos comerciais analisados apresentaram indícios de utilizarem-na para gerenciar seus resultados, $30 \%$ dos bancos não utilizaram as operações com títulos e valores mobiliários para gerenciar resultados e 15\% dos bancos foram excluídos das análises.

É importante ressaltar que o objetivo deste trabalho era simplesmente detectar a presença de indícios da utilização das operações com títulos e valores mobiliários para gerenciar os resultados. Assim, este trabalho não 
levou em consideração a freqüência e a intensidade com que este gerenciamento é praticado.

Para as análises relativas às operações de crédito, o principal indicador utilizado foi a provisão excedente em relação à provisão exigida pela legislação vigente. Apesar da provisão excedente ser muito pequena em relação ao total da carteira de operações de crédito, seu valor é significativo se comparado com os resultados mensais auferidos pelos bancos comerciais. Apenas dezessete instituições foram analisadas, pois três não apresentaram provisão excedente.

Concluiu-se que, $30 \%$ dos bancos comerciais não utilizaram as operações de crédito para gerenciar seus resultados. Outros 30\% dos bancos analisados apresentaram indícios de haver gerenciado seus resultados por meio da provisão para operações de crédito. Finalmente, os resultados são inconclusivos para $25 \%$ dos bancos comerciais.

No que tange às contingências passivas os resultados obtidos também foram inconclusivos, exceto para as contingências trabalhistas que não são utilizadas para gerenciar resultados.

Tabela 5.1 - Resultados obtidos para os 20 maiores conglomerados

\begin{tabular}{ccccc}
\hline Resultado & $\begin{array}{c}\text { Ágios em } \\
\text { Investimentos }\end{array}$ & $\begin{array}{c}\text { Operações } \\
\text { com TVM }\end{array}$ & $\begin{array}{c}\text { Operações } \\
\text { de Crédito }\end{array}$ & $\begin{array}{c}\text { Passivos } \\
\text { Contingentes }\end{array}$ \\
\hline $\begin{array}{c}\text { Gerenciam } \\
\text { resultados }\end{array}$ & 2 & 11 & 6 & - \\
\hline $\begin{array}{c}\text { Não gerenciam } \\
\text { resultados }\end{array}$ & - & 6 & 6 & - \\
\hline $\begin{array}{c}\text { Análises } \\
\text { inconclusivas }\end{array}$ & 1 & - & 5 & 20 \\
\hline $\begin{array}{c}\text { Excluídos da } \\
\text { amostra* }\end{array}$ & 17 & 3 & 3 & - \\
\hline
\end{tabular}

* Bancos cujos dados não possibilitaram a análise 
A Tabela 5.1 resume os resultados obtidos, apresentando a quantidade de bancos comerciais analisados em números absolutos.

Dos vinte bancos analisados, apenas quatro deles não apresentaram indícios de gerenciamento de resultado em nenhuma das áreas analisadas. Em contrapartida, uma instituição apresentou indícios nas três áreas em foram obtidos resultados conclusivos. Outro banco, apresentou indícios de gerenciamento para uma área e resultados inconclusivos nas outras duas.

Dos demais quatorze bancos comerciais: oito, apresentaram indícios de gerenciamento de resultados relativos a apenas uma área; cinco, apresentaram indícios para uma área e resultados inconclusivos para outra; finalmente, um banco apresentou indícios para duas das três áreas com resultados conclusivos.

Trabalhos futuros poderiam ser conduzidos em vários aspectos abordados nesta tese, tais como: (i) ampliar a amostra de bancos que contabilizaram ágio em investimentos em controladas e coligadas. (ii) investigar a influência da composição das carteiras, em relação ao nível de risco de crédito, no gerenciamento de resultados; (iii) aprofundar pesquisa sobre contingências passivas, considerando informações mais analíticas sobre os tipos de contingências, como as disponíveis nas notas explicativas às demonstrações contábeis. 


\section{BIBLIOGRAFIA}

ALMEIDA, Jose Elias Feres de; LOPES, Alexsandro Broedel; TONIATO, João

\& COSTA, Fábio Moraes da. Earnings management and industry classification in Brazil: an exploratory investigation. In: Seminário USP de Controladoria e Contabilidade, 5., 2005, São Paulo.

ALMEIDA, José Elias Feres de; COSTA, Fábio Moraes da; FARIA, Luiz Henrique Lima \& BRANDÃO, Marcelo Moll. Earnings management no Brasil: grupos estratégicos como nova variável explanatória. In: Seminário USP de Controladoria e Contabilidade, 6., 2006, São Paulo.

ANDRADE, Maria Margarida de. Como preparar trabalhos para cursos de pós-graduação. 3. ed. São Paulo: Atlas, 1999.

ARAÚJO, Adriana Maria Procópio de \& ASSAF NETO, Alexandre. Finanças empresarias e contabilidade. In: FACEF PESQUISA, v. 7, n. 3, 2004. Disponível em <http://www.facef.br/facefpesquisa/2004/nr3/1_ARAUJO_ ASSAF_NETO.pdf>. Acesso em: 09 nov. 2006. 
BANCO CENTRAL DO BRASIL. Circular 꾸 3068, de 8 de novembro de 2001. Estabelece critérios para registro e avaliação contábil de títulos e valores mobiliários.

. Circular $n^{\circ}$ 3082, de 30 de janeiro de 2002. Estabelece e consolida critérios para registro e avaliação contábil de instrumentos financeiros derivativos.

Circular $n^{\circ}$ 3171, de 30 de dezembro de 2002. Estabelece procedimentos para reconhecimento, registro contábil e avaliação de créditos tributários e obrigações fiscais diferidas.

- Contingências fiscais, trabalhistas e cíveis - temas fiscais relevantes para a supervisão bancária. Apostila para uso interno, elaborada pela equipe DESUP/DIESP/SUESP-01. Junho de 2006.

BANCO BRADESCO S.A. Demonstrações financeiras, parecer dos auditores independentes, resumo do relatório do comitê de auditoria e parecer do conselho fiscal. Disponível em <http://www.bradescori.com.br/uploads/ conteudo/9363/02_DF.pdf>. Acesso em 05 nov. 2006.

BANCO ITAÚ HOLDING FINANCEIRA S.A. e ITAÚSA - INVESTIMENTOS ITAÚ S.A. Fato relevante. Divulgado em 25 de Outubro de 2006.

BRASIL. Lei no 6404, de 15 de dezembro de 1976. Dispõe sobre as Sociedades por Ações.

. Lei ํo 9249, de 26 de dezembro de 1995. Altera a legislação do imposto de renda das pessoas jurídicas, bem como da contribuição social sobre o lucro líquido, e dá outras providências. 
Lei Complementar № 105, de 10 de janeiro de 2001. Dispõe sobre o sigilo das operações de instituições financeiras e dá outras providências.

BURTON, Maureen \& LOMBRA, Ray. The financial system and the economy: principles of money and banking. 2. ed. Cincinnati: South-Western College, 2000.

CARDOSO, Ricardo Lopes \& MARTINEZ, Antonio Lopo. Gerenciamento de resultados contábeis no Brasil mediante decisões operacionais. In: Encontro da ANPAD (EnANPAD), 30., 2006, Salvador.

CARDOSO, Ricardo Lopes; AQUINO, André Carlos Busanelli de; ALMEIDA, José Elias Feres de \& NEVES, Antonio José Barbosa das. Acumulações discricionárias, liquidez e governança corporativa divulgada no Brasil. In: Encontro da ANPAD (EnANPAD), 30., 2006, Salvador.

COLLI, José Alexandre \& FONTANA, Marino. Contabilidade bancária. 4. ed. São Paulo: Atlas, 1988.

COMISSÃO DE VALORES MOBILIÁRIOS. Instrução CVM № 247, de 27 de março de 1996. Dispõe sobre a avaliação de investimentos em sociedades coligadas e controladas e sobre os procedimentos para elaboração e divulgação das demonstrações contábeis consolidadas, para o pleno atendimento aos Princípios Fundamentais de Contabilidade.

. Deliberação CVM nํ4ㄹ, de 03 de outubro de 2005. Aprova o Pronunciamento do IBRACON NPC № 22 sobre Provisões, Passivos, Contingências Passivas e Contingências Ativas. 
CONSELHO FEDERAL DE CONTABILIDADE. Resolução CFC nำ 750, de 29 de dezembro de 1993. Dispõe sobre os Princípios Fundamentais de Contabilidade (PFC).

CONSELHO MONETÁRIO NACIONAL. Resolução no 2682, de 21 de dezembro de 1999. Dispõe sobre critérios de classificação das operações de credito e regras para constituição de provisão para créditos de liquidação duvidosa.

CORRAR, Luiz João; PAULO, Edílson \& MARTINS, Eliseu. Detecção do gerenciamento de resultados pela análise do diferimento tributário. Revista de Administração de Empresas (RAE), São Paulo, Vol. 47, N. 1, Janeiro-Março 2007.

CUPERTINO, César Medeiros. Gerenciamento fraudulento de resultados contábeis: o caso banco nacional. In: Encontro da ANPAD (EnANPAD), 28., 2004, Curitiba.

. Earnings management: evidência empírica. In: Seminário USP de Controladoria e Contabilidade, 4., 2004, São Paulo.

DECHOW, Patricia M.; SLOAN, Richard G. \& SWEENEY, Amy P. Detecting earnings management. The Accounting Review, v. 70, n. 2, 1995.

FÁVERO, Luiz Paulo Lopes. O mercado imobiliário residencial da região metropolitana de São Paulo: uma aplicação de modelos de comercialização hedônica de regressão e correlação canônica. 2005. Tese (Doutorado em Administração) - Faculdade de Economia, Administração e Contabilidade, Universidade de São Paulo, São Paulo. 
FERRARI, Alfonso Trujillo. Metodologia da pesquisa científica. São Paulo: McGraw-Hill, 1982.

FUJI, Alessandra Hirano. Gerenciamento de resultados contábeis no âmbito das instituições financeiras atuantes no Brasil. 2004. Dissertação (Mestrado em Controladoria e Contabilidade) - Faculdade de Economia, Administração e Contabilidade, Universidade de São Paulo, São Paulo.

FUJI, Alessandra Hirano \& CARVALHO, Luiz Nelson Guedes de. Earnings management no contexto bancário brasileiro. In: Seminário USP de Controladoria e Contabilidade, 5., 2005, São Paulo.

GUJARATI, Damodar N. Econometria básica. São Paulo: Makron Books, 2000.

HAJJ, Zaina Said El. Evolução e desempenho dos bancos durante o plano real. 2005. Tese (Doutorado em Controladoria e Contabilidade) - Faculdade de Economia, Administração e Contabilidade, Universidade de São Paulo, São Paulo.

HENDRIKSEN, Eldon S. \& VAN BREDA, Michael F. Teoria da contabilidade. São Paulo: Atlas, 1999.

HICKS, John Richard. Value and capital. Oxford: Clarendon Press, 1946.

INSTITUTO BRASILEIRO DOS AUDITORES INDEPENDENTES - IBRACON. Pronunciamento IBRACON NPC no 6 - Investimentos - Participações em Outras Sociedades. Aprovada pela Diretoria Nacional em dezembro de 1981. Pronunciamento IBRACON NPC no 14 - Receitas e Despesas Resultados. Aprovado pela Diretoria Nacional em em 18 de janeiro de 2001. 
IUDÍCIBUS, Sérgio de \& MARION, José Carlos. Introdução à teoria da contabilidade. 2 ed. São Paulo: Atlas, 2000.

IUDÍCIBUS, Sérgio de; MARTINS, Eliseu \& GELBCKE, Ernesto Rubens. Manual de contabilidade das sociedades por ações (aplicável às demais sociedades). 5 ed. São Paulo: Atlas, 2000.

IUDÍCIBUS, Sérgio de. Teoria da contabilidade. 6 ed. São Paulo: Atlas, 2000.

JONES, Jeniffer J. Earnings management during import relief investigations. Journal of Accounting Research. Chicago, V. 29, N. 2, Autumn 1991.

KANG, Sok-Hyon \& SIVARAMAKRISHNAN, K. Issues in testing earnings management: an instrumental variable approach. Journal of Accounting Research, V. 33, N. 2, 1995.

LAKATOS, Eva Maria. Metodologia do trabalho científico. São Paulo: Atlas, 1990.

LOPES, Alexsandro Broedel \& MARTINS, Eliseu. Teoria da contabilidade: uma nova abordagem. São Paulo: Atlas, 2005.

LOPES, Alexsandro Broedel \& TUKAMOTO, Yhurika Sandra. Contribuição ao estudo do "gerenciamento" de resultados: uma comparação entre as companhias abertas brasileiras emissoras de ADRs e não-emissoras de ADRs. Revista de Administração da Universidade de São Paulo (RAUSP), São Paulo, Vol. 42, N. 1, Janeiro-Março 2007.

MARION, José Carlos. Contabilidade empresarial. 12 ed. São Paulo: Atlas, 2006. 
MARTINEZ, Antonio Lopo. "Gerenciamento" dos resultados contábeis: estudo empírico das companhias abertas brasileiras. 2001. Tese (Doutorado em Controladoria e Contabilidade) - Faculdade de Economia, Administração e Contabilidade, Universidade de São Paulo, São Paulo.

. Earnings management: how the companies come up with the numbers they want. An empirical study of brazilian public companies. In: Seminário USP de Controladoria e Contabilidade, 3., 2003, São Paulo.

. Detectando earnings management no brasil: estimando as acumulações discricionárias. In: Seminário USP de Controladoria e Contabilidade, 4., 2004, São Paulo.

MARTINS, Gilberto de Andrade. Manual para elaboração de monografias. São Paulo: Atlas, 1992.

MATOS, Felipe Faissol Janot de \& SANCOVSCHI Moacir. Earnings management: the case of lucent technologies. In: Seminário USP de Controladoria e Contabilidade, 3., 2003, São Paulo.

MATOS, Orlando Carneiro de. Econometria básica. 3. ed. São Paulo: Atlas, 2000.

NIYAMA, Jorge Katsumi \& GOMES, Amaro L. Oliveira. Contabilidade de instituições financeiras. 2 ed. São Paulo: Atlas, 2002.

PAULO, Edílson. Gerenciamento de resultados e a oferta pública de ações pelas companhias abertas brasileiras. In: Encontro da ANPAD (EnANPAD), 30., 2006, Salvador.

PAULO, Edílson; LIMA, Gerlando Augusto Sampaio Franco de \& LIMA, Iran Siqueira. A influência da cobertura dos analistas financeiros sobre o 
gerenciamento de resultados das companhias abertas brasileiras. In: Seminário USP de Controladoria e Contabilidade, 6., 2006, São Paulo.

PAULO, Edílson; CORRAR, Luiz João \& MARTINS, Eliseu. Detectando gerenciamento de resultados pela análise do diferimento tributário. In: Encontro da ANPAD (EnANPAD), 30., 2006, Salvador.

PURIFICAÇÃO, Carlos Alberto da. Contabilidade bancária. 3 ed. São Paulo: Atlas, 1995.

RAMOS, Gizele Martins \& MARTINEZ, Antonio Lopo. Governança Corporativa e Gerenciamento de Resultados Contábeis. In: Encontro da ANPAD (EnANPAD), 30., 2006, Salvador.

RODRIGUES, Adriano. Gerenciamento dos resultados contábeis através de receitas e despesas não-operacionais: estudo empírico das companhias "nível 1" - bovespa. In: Seminário USP de Controladoria e Contabilidade, 6., 2006, São Paulo.

RODRIGUES, Adriano; PAULO, Edílson \& CARVALHO, L. Nelson. Gerenciamento de resultados por meio das transações entre companhias brasileiras interligadas. Revista de Administração da Universidade de São Paulo (RAUSP), São Paulo, Vol. 42, N. 2, Abril-Junho 2007.

SAUNDERS, Anthony. Administração de instituições financeiras. São Paulo: Atlas, 2000.

SCHMIDT, Paulo. Lucro distribuível. Disponível em <http://www.ufrgs.br/necon/ lucro.pdf>. Acesso em 09 nov. 2006.

SCHIPPER, Katherine. Commentary on earnings management. Accounting Horizons, Sarasota, Vol. 3, p. 91-102, December 1989. 
SILVA JUNIOR, Daphnis Theodoro da. O conteúdo informacional dos contratos futuros de Ibovespa. 2006. Tese (Doutorado em Controladoria e Contabilidade) - Faculdade de Economia, Administração e Contabilidade, Universidade de São Paulo, São Paulo.

SILVEIRA, Márcia Adriana da. Gerenciamento de resultados e opções de ações: uma pesquisa em companhias abertas no Brasil. In: Seminário USP de Controladoria e Contabilidade, 6., 2006, São Paulo.

TUKAMOTO, Yhurika Sandra. Contribuição ao estudo do "gerenciamento" de resultados: uma comparação entre as companhias abertas brasileiras emissoras de ADRs e não emissoras de ADRs. 2004. Dissertação (Mestrado em Controladoria e Contabilidade) - Faculdade de Economia, Administração e Contabilidade, Universidade de São Paulo, São Paulo.

UNIBANCO - UNIÃO DE BANCOS BRASILEIROS S.A. Fato relevante. Divulgado em 26 de Outubro de 2006. Disponível em: <http://www.ri.unibanco. com.br/por/mod/index.asp?param=117345>. Acesso em 05 nov. 2006.

VERA, Asti. Metodología de la investigación. Buenos Aires: Kapelusz, 1968.

WOELFEL, Charloes J. The handbook of bank accounting. Chicago: Probus, 1993. 


\section{ANEXO}

\section{Conglomerado Bancário BB}

Código: 49906

Sigla: BB

Tipo: Publico Federal

Instituição Líder: Banco Do Brasil S.A. (00.000.000)

CGC da Holding: 00.000.000

Nome da Holding: Banco Do Brasil S.A.

Disponível em: http://www5.bcb.gov.br/fis/cosif/DCOp2.asp?PAR=1\&P=49906. Acesso em: 19 jul. 2007.

\section{Conglomerado Bancário BRADESCO}

Código: 10045

Sigla: BRADESCO

Tipo: Privado Nacional

Instituição Líder: Banco Bradesco S.A. (60.746.948)

CGC da Holding: 61.529 .343

Nome da Holding: Cidade De Deus Companhia Comercial De Participacoes

Disponível em: http://www5.bcb.gov.br/fis/cosif/DCOp2.asp?PAR=1\&P=10045. Acesso em: 19 jul. 2007. 


\section{INSTITIÇÃo BANCÁRIA INDEPENDENTE CEF}

Instituição: CAIXA ECONÔMICA FEDERAL

CGC: 00.360 .305

Natureza Jurídica: Empresa Pública

Tipo Instituição: Segmento: Caixa Econômica Federal

Disponível em: http://www5.bcb.gov.br/fis/cosif/DadosCadastrais.asp?

PARAMETRO=00360305M. Acesso em: 19 jul. 2007.

\section{Conglomerado Bancário ITAÚ}

Código: 10069

Sigla: ITAU

Tipo: Privado Nacional

Instituição Líder: Banco Itaú Holding Financeira S.A. (60.872.504)

CGC da Holding: 61.532 .644

Nome da Holding: Itausa-Investimentos Itaú S/A.

Disponível em: http://www5.bcb.gov.br/fis/cosif/DCOp2.asp?PAR=1\&P=10069. Acesso em: 19 jul. 2007.

\section{Conglomerado Bancário ABN AMRO}

Código: 10076

Sigla: ABN AMRO

Tipo: Nacional Com Controle Estrangeiro

Instituição Líder: Banco Abn Amro Real S.A. (33.066.408)

CGC da Holding: 33.066.408

Nome da Holding: Banco Abn Amro Real S.A.

Disponível em: http://www5.bcb.gov.br/fis/cosif/DCOp2.asp?PAR=1\&P=10076. Acesso em: 19 jul. 2007. 


\section{CoNGLOMERADO BANCÁRIO SANTANDER BANESPA}

Código: 30379

Sigla: SANTANDER BANESPA

Tipo: Nacional Com Controle Estrangeiro

Instituição Líder: Banco Santander Banespa S.A. (90.400.888)

CGC da Holding: 90.400 .888

Nome da Holding: Banco Santander Banespa S.A.

Disponível em: http://www5.bcb.gov.br/fis/cosif/DCOp2.asp?PAR=1\&P=30379. Acesso em: 19 jul. 2007.

\section{Conglomerado BancáRIo UNIBANCO}

Código: 10100

Sigla: UNIBANCO

Tipo: Nacional Participação Estrangeira

Instituição Líder: Unibanco-Uniao De Bancos Brasileiros S.A. (33.700.394)

CGC da Holding: 00.022.034

Nome da Holding: Unibanco Holdings S A

Disponível em: http://www5.bcb.gov.br/fis/cosif/DCOp2.asp?PAR=1\&P=10100. Acesso em: 19 jul. 2007.

\section{Conglomerado Bancário SAFRA}

Código: 10083

Sigla: SAFRA

Tipo: Privado Nacional

Instituição Líder: Banco Safra S.A. (58.160.789)

CGC da Holding: 43.826 .833

Nome da Holding: Letero Empreendimentos, Publicidade E Participacoes S/A Disponível em: http://www5.bcb.gov.br/fis/cosif/DCOp2.asp?PAR=1\&P=10083. Acesso em: 19 jul. 2007. 


\section{Conglomerado BancÁRIo HSBC}

Código: 51152

Sigla: HSBC

Tipo: Nacional Com Controle Estrangeiro

Instituição Líder: Hsbc Bank Brasil S.A. - Banco Multiplo (01.701.201)

CGC da Holding: 01.701.201

Nome da Holding: Hsbc Bank Brasil S.A. - Banco Multiplo

Disponível em: http://www5.bcb.gov.br/fis/cosif/DCOp2.asp?PAR=1\&P=51152.

Acesso em: 19 jul. 2007.

\section{Conglomerado Bancário VOTORANTIM}

Código: 51011

Sigla: VOTORANTIM

Tipo: Privado Nacional

Instituição Líder: Banco Votorantim S.A. (59.588.111)

CGC da Holding: 59.588.111

Nome da Holding: Banco Votorantim S.A.

Disponível em: http://www5.bcb.gov.br/fis/cosif/DCOp2.asp?PAR=1\&P=51011. Acesso em: 19 jul. 2007.

\section{INSTITIÇÃo BANCÁRIA INDEPENDENTE NOSSA CAIXA}

Instituição: BCO NOSSA CAIXA S.A.

CGC: 43.073 .394

Natureza Jurídica: Sociedade Anônima De Capital Aberto

Tipo Instituição: Segmento: Banco Múltiplo

Disponível em: http://www5.bcb.gov.br/fis/cosif/DadosCadastrais.asp?

PARAMETRO=43073394U. Acesso em: 19 jul. 2007. 


\section{Conglomerado BancáRIo CITIBANK}

Código: 30403

Sigla: CITIBANK

Tipo: Estrangeiro

Instituição Líder: Banco Citibank S.A. (33.479.023)

CGC da Holding: 33.479 .023

Nome da Holding: Banco Citibank S.A.

Disponível em: http://www5.bcb.gov.br/fis/cosif/DCOp2.asp?PAR=1\&P=30403. Acesso em: 19 jul. 2007.

\section{Conglomerado Bancário UBS PACTUAL}

Código: 49944

Sigla: UBS PACTUAL

Tipo: Nacional Com Controle Estrangeiro

Instituição Líder: Banco Ubs Pactual S.A. (30.306.294)

CGC da Holding: 30.306.294

Nome da Holding: Banco Ubs Pactual S.A.

Disponível em: http://www5.bcb.gov.br/fis/cosif/DCOp2.asp?PAR=1\&P=49944. Acesso em: 19 jul. 2007.

\section{Conglomerado BancÁRIo BANRISUL}

Código: 30173

Sigla: BANRISUL

Tipo: Publico Estadual

Instituição Líder: Banco Do Estado Do Rio Grande Do Sul S.A. (92.702.067)

CGC da Holding: 92.702.067

Nome da Holding: Banco Do Estado Do Rio Grande Do Sul S.A.

Disponível em: http://www5.bcb.gov.br/fis/cosif/DCOp2.asp?PAR=1\&P=30173. Acesso em: 19 jul. 2007. 


\section{Conglomerado BancÁRIo BBM}

Código: 30207

Sigla: BBM

Tipo: Privado Nacional

Instituição Líder: Banco Bbm S/A (15.114.366)

CGC da Holding: 14.308.514

Nome da Holding: Participacoes Industriais Do Nordeste S/A

Disponível em: http://www5.bcb.gov.br/fis/cosif/DCOp2.asp?PAR=1\&P=30207.

Acesso em: 19 jul. 2007.

\section{INSTITIÇÃo BANCÁRIA INDEPENDENTE BNB}

Instituição: BCO DO NORDESTE DO BRASIL S.A.

CGC: 07.237 .373

Natureza Jurídica: Sociedade De Economia Mista Aberta

Tipo Instituição: Segmento: Banco Múltiplo

Disponível em: http://www5.bcb.gov.br/fis/cosif/DadosCadastrais.asp?

PARAMETRO=07237373U >. Acesso em: 19 jul. 2007.

\section{Conglomerado Bancário ALFA}

Código: 51293

Sigla: ALFA

Tipo: Privado Nacional

Instituição Líder: Banco Alfa De Investimento S.A. (60.770.336)

CGC da Holding: 04.590 .759

Nome da Holding: Afl Administracao, Participacoes E Representacoes Ltda.

Disponível em: http://www5.bcb.gov.br/fis/cosif/DCOp2.asp?PAR=1\&P=51293. Acesso em: 19 jul. 2007. 


\section{Conglomerado BANCÁRIO BNP PARIBAS}

Código: 51516

Sigla: BNP PARIBAS

Tipo: Nacional Com Controle Estrangeiro

Instituição Líder: Banco Bnp Paribas Brasil S.A. (01.522.368)

CGC da Holding:

Nome da Holding:

Disponível em: http://www5.bcb.gov.br/fis/cosif/DCOp2.asp?PAR=1\&P=51516. Acesso em: 19 jul. 2007.

\section{Conglomerado Bancário DEUTSCHE}

Código: 51183

Sigla: DEUTSCHE

Tipo: Nacional Com Controle Estrangeiro

Instituição Líder: Deutsche Bank S.A.Banco Alemao (62.331.228)

CGC da Holding: 62.331.228

Nome da Holding: Deutsche Bank S.A.Banco Alemao

Disponível em: http://www5.bcb.gov.br/fis/cosif/DCOp2.asp?PAR=1\&P=51183. Acesso em: 19 jul. 2007.

\section{Conglomerado BANCÁRIO CREDIT SUISSE}

Código: 30771

Sigla: CREDIT SUISSE

Tipo: Nacional Com Controle Estrangeiro

Instituição Líder: Banco Credit Suisse (Brasil) S.A. (32.062.580)

CGC da Holding: 33.987 .793

Nome da Holding: Banco De Investimentos Credit Suisse (Brasil) S.A.

Disponível em: http://www5.bcb.gov.br/fis/cosif/DCOp2.asp?PAR=1\&P=30771. Acesso em: 19 jul. 2007. 